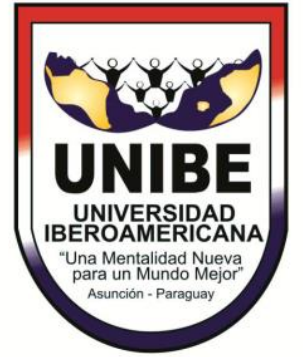

MAESTRIA EN CIENCIA DE LA EDUCACIÓN

ROSEMARY LEOCÁDIA GOMES SILVA

PRÁTICAS EDUCATIVAS DA EQUIPE MULTIDISCIPLINAR DE SAÚDE NO PROCESSO CONTÍNUO DE EDUCAÇÃO DE CRIANÇAS E ADOLESCENTES COM DIABETES MELLITUS TIPO 1.

Asunción - Py 


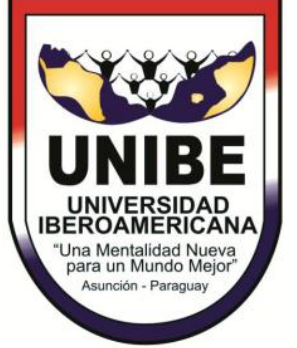

ROSEMARY LEOCÁDIA GOMES SILVA COM DIABETES MELLITUS TIPO 1.

Dissertação apresentada à Universidad Iberoamericana como requisito parcial para a obtenção do título de Mestre em Saúde Pública.

Tutor: Prof. Dr. Roberto Wagner Scherr Campos

Asunción - Py 
№ CUTTER Silva, Rosemary Leocádia Gomes, 2016

Título principal: Práticas educativas da equipe multidisciplinar de saúde no processo contínuo de educação de crianças e adolescentes com diabetes mellitus tipo 1./ Rosemary Leocádia Gomes Silva. 2016.

113 f.: il. color. ; $30 \mathrm{~cm}$

Dissertación de Maestria Em Ciencias de la Educación. Universidad Iberoamericana - Asunción - Paraguay.

1. Adolescente. 2. Criança. 3. Diabetes Mellitus Tipo 1. 4. Educação Interdisciplinar.

№ $\mathrm{CDU}$ 


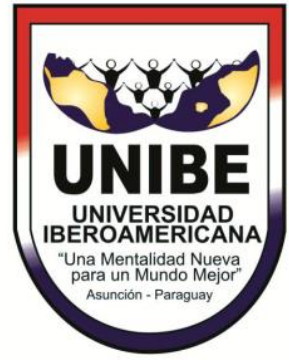

ROSEMARY LEOCÁDIA GOMES SILVA

\title{
PRÁTICAS EDUCATIVAS DA EQUIPE MULTIDISCIPLINAR DE SAÚDE NO PROCESSO CONTÍNUO DE EDUCAÇÃO DE CRIANÇAS E ADOLESCENTES COM DIABETES MELLITUS TIPO 1.
}

\author{
DISSERTAÇÃO DE MESTRADO
}

UNIVERSIDAD IBEROAMERICANA

SAÚDE PÚBLICA

Asunción, de de

Aprovado com o grau:

Banca examinadora:

\footnotetext{
Professor (a) Dr (a). Nome do Presidente da banca
}

Professor (a) Dr (a). Nome do $2^{\circ}$ componente da banca

Professor (a) Dr (a). Nome do 3ํcomponente da banca 


\section{DEDICATÓRIA}

Dedico a Deus meu amigo, Ao meu pai (in memoria) Antônio Alves Gomes, meu anjo, abraço em silencio. A minha mãe Terezinha Leocadia eterna gratidão. Aos meus Irmãos Marilda, Zé Leo, Mauricio, Antonio Ricardo, Gabriela e Mariângela orgulho de tê-los em minha vida! A minha linda filha Esther Gomes, grande amiga por ser minha maior fonte de vida e inspiração. Ao Marcos meu tesouro pelo amor, compreensão e apoio incondicional, eu te amo! Aos cunhados (as), sobrinhos, primos, afilhados, enteados que torcem pelo meu sucesso. Aos amigos do ASV que se fizeram presentes. 


\section{AGRADECIMENTOS}

À Universidade lberoamericana por proporcionar esta oportunidade;

Ao Prof. Dr. Roberto Wagner Scherr Campos, meu orientador e exemplo profissional, pela paciência e confiança.

Aos professores Doutores, Ricardo de Bonis, Glória Comas de Alvarez, Rosa Maria Ruffinelli, Nora Asunción Aquino, Carmelindo Maliska, Estela Mary Mongelós Ojeda. Funcionários da UNIBE pela solicitude e solidariedade perante minhas dificuldades. Aos amigos de mestrado da turma mais divertida que compartilharam comigo esses momentos de aprendizado, principalmente pela paciência e companheirismo.

Enfim, a todos aqueles que de uma maneira ou de outra colaboraram para que este trajeto pudesse ser concluído. 


\section{RESUMO}

A Diabetes Mellitus Tipo 1, que afeta crianças e adolescentes tem aumentado de forma significativa, sendo esta uma das patologias mais importantes na fase infantojuvenil. É considerada uma doença crônica pela Organização Mundial de Saúde (OMS), pois interfere no funcionamento da vida da criança e do adolescente além de gerar hospitalizações e complicações que podem levar ao óbito. Tal patologia traz mudanças significativas na vida da criança, do adolescente e dos familiares por terem que adaptar a uma nova fase da vida do paciente. Hábitos alimentares são modificados para o paciente, que acaba afetando todos os familiares, gerando por vezes conflitos entre irmãos. Inúmeras outras questões na vida dos mesmos são modificadas alem da alimentação: uso da insulina, exercícios físicos, controle glicêmico, ficando estes "escravos da patologia". A integração dos profissionais de saúde, pacientes e familiares ainda deixa a desejar, pois a adesão ao tratamento pelos pacientes é muito difícil por não saberem sobre a doença, sua causa e conseqüências. Tal estudo buscou então realizar levantamento sobre práticas educativas realizadas pela equipe multidisciplinar de saúde no processo contínuo de educação de crianças e adolescentes com DM1 e seus familiares. Utilizou-se de pesquisa bibliográfica de artigos, livros pertinentes ao assunto. Observou-se que há uma defasagem na integração de saberes e conhecimentos dos profissionais envolvidos, acreditando que para ajudar esse público alvo em questão deve haver uma educação voltada para os profissionais e consequentemente para a criança, o adolescente e os familiares.

Palavras-chave: Adolescente. Criança. Diabetes Melittus Tipo 1. Educação Interdisciplinar. 


\section{RESUMEN}

La diabetes mellitus tipo 1, que afecta a los niños y adolescentes se ha incrementado significativamente, lo cual es una de las enfermedades más importantes en la etapa juvenil. Se considera una enfermedad crónica por la Organización Mundial de la Salud (OMS), ya que interfiere con el funcionamiento de la vida y adolescentes del niño y generar hospitalizaciones y complicaciones que pueden conducir a la muerte. Esta enfermedad produce cambios significativos en la vida del niño, adolescente y su familia por tener que adaptarse a una nueva fase de la vida del paciente. los hábitos alimentarios se modifican para el paciente, que en última instancia afecta a todos los miembros de la familia, a veces la generación de conflictos entre hermanos. Otros numerosos problemas en la vida de estos se modifican más allá del poder: el uso de la insulina, el ejercicio, el control glucémico, conseguir estos "esclavos de la enfermedad." La integración de los profesionales de la salud, los pacientes y sus familiares aún deja que desear, ya que la adherencia al tratamiento por los pacientes es muy difícil no saber sobre la enfermedad, sus causas y consecuencias. Este estudio buscó entonces llevar a cabo una encuesta sobre las prácticas educativas llevadas a cabo por un equipo multidisciplinario de salud en el proceso continuo de la educación de los niños y adolescentes con diabetes tipo 1 y sus familias. Utilizamos artículos de investigación bibliográficas, libros relacionados con el tema. Se observó que existe un retraso en la integración del conocimiento y la experiencia de los profesionales que intervienen, en la creencia de que para ayudar a este grupo objetivo en cuestión debe ser una educación para los profesionales y por lo tanto para el niño, el adolescente y la familia.

Palabras clave: adolescentes. Niño. Mellitus diabetes tipo 1. Interdisciplinaria de Educación. 


\section{LISTA DE QUADROS}

Quadro 1 - Modelo de Compreensão do desenvolvimento do adolescente 30

Quadro 2 - Cuidados e Orientações para a criança com diabetes na escola 40 Quadro 3 - Fatores que facilitam e dificultam o manejo ao diabetes na perspectiva da criança - Ribeirão Preto 2009 


\section{LISTA DE FIGURAS}

Figura 1 - Aspectos da prática coletiva de educação em saúde 


\section{LISTA DE TABELAS}

Tabela 1 - Critérios para avaliação da eficácia do programa da educação

Tabela 2 - Importantes fases do desenvolvimento e seus efeitos no diabetes de crianças e adolescentes

Tabela 3 - Descrição do nível de conhecimento e da fundamentação das práticas coletivas de Educação em Saúde Coletiva, de acordo com a categoria profissional, Contagem/MG (2011)

Tabela 4 - Artigos Incluídos e Excluídos 


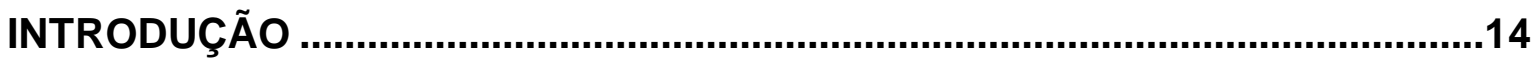

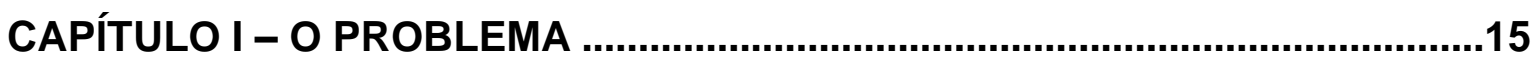

1.1 Situação Problema ........................................................................................15

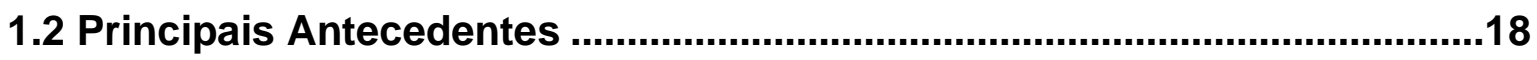

1.3 Delimitação do Estudo .......................................................................19

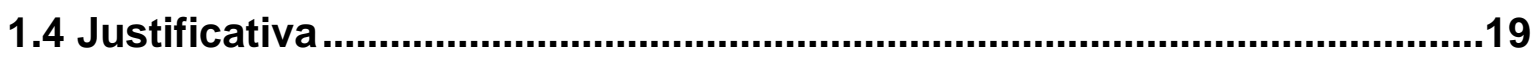

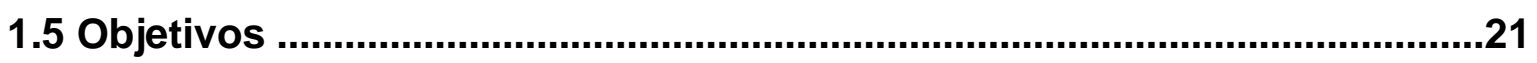

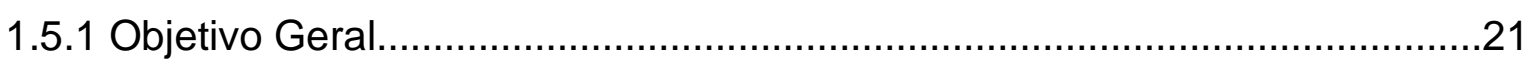

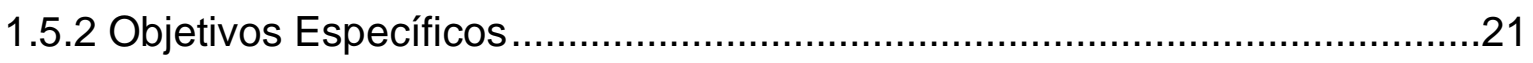

1.6 Questões Investigativas ..............................................................................21

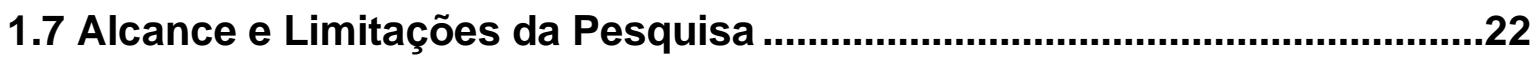

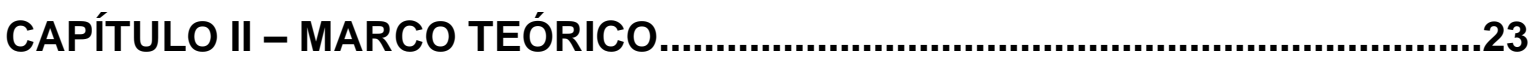

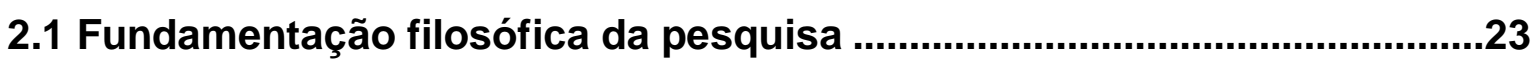

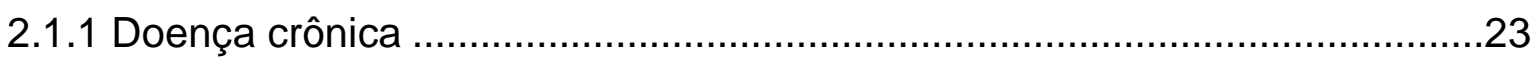

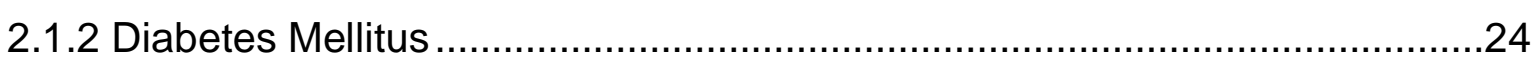

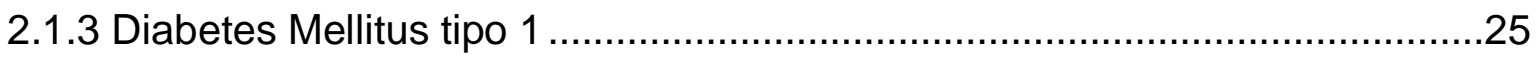

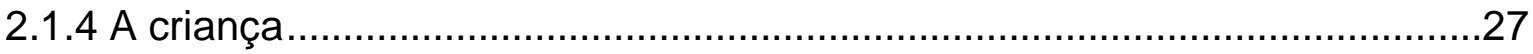

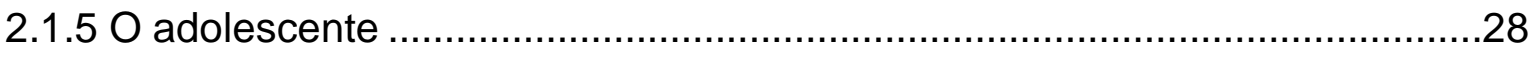

2.2 Responsabilidade Social do Enfermeiro....................................................31

2.3 Políticas públicas para atendimento à criança $\mathrm{cm}$ Diabetes Mellitus.......32

2.4 Atuação e prática da equipe multidisciplinar e o papel de cada um .........34

2.4.1 Estruturação interdisciplinar: a equipe ................................................... 41

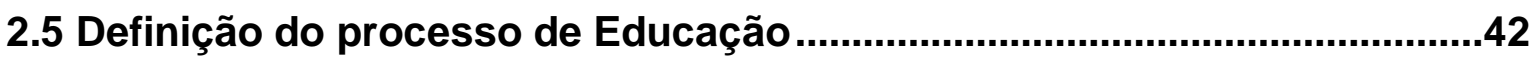

2.5.1 O paciente: a quem devemos educar.......................................................42

2.5.2 Estruturação do conteúdo: o que educar ........................................................43

2.6 Perspectiva das crianças com DM sua real dificuldade e os fatores que interferem na sua vida cotidiana ......................................................................

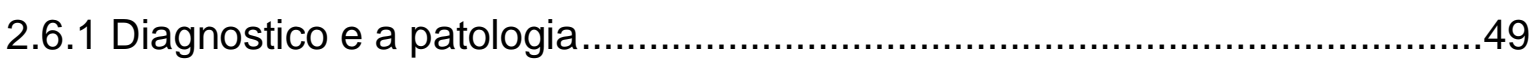

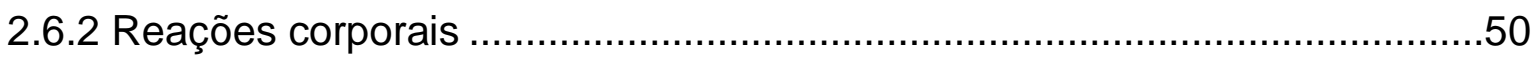

2.6.3 Controle da alimentação e uso da insulina ................................................50 


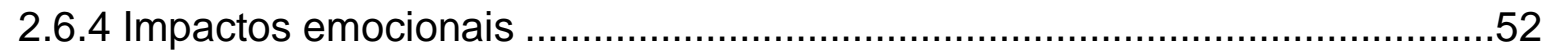

2.6.5 Dependência dos pais e transgressão …………......................................55

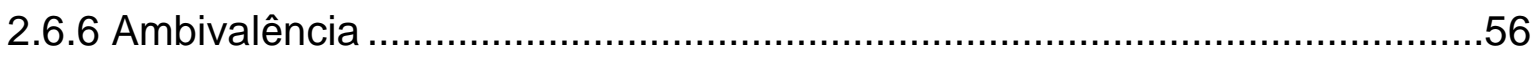

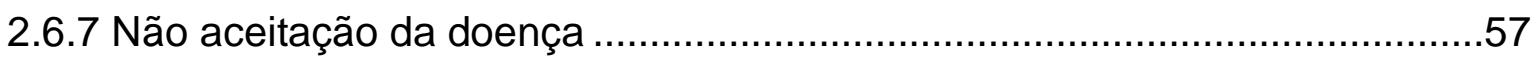

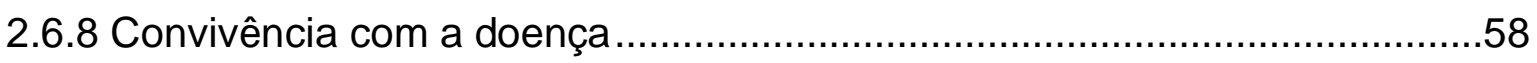

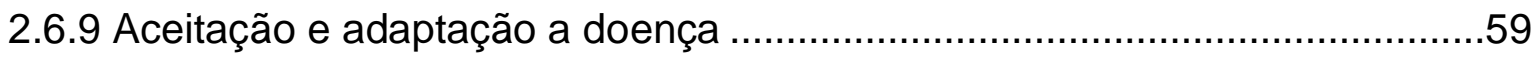

2.6.10 Compreensão e percepção dos envolvidos .............................................60

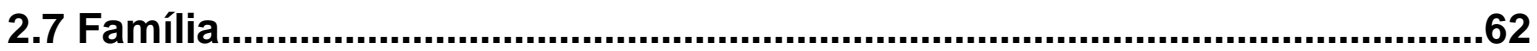

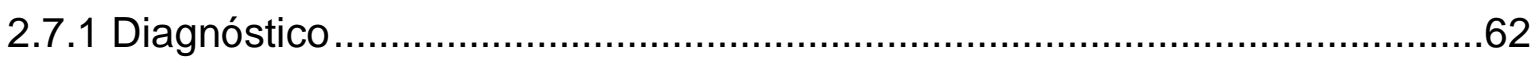

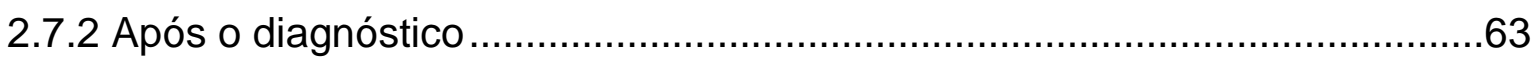

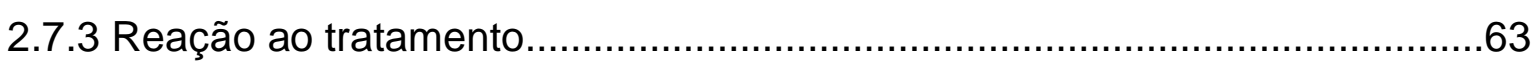

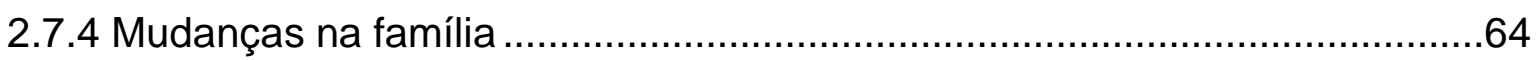

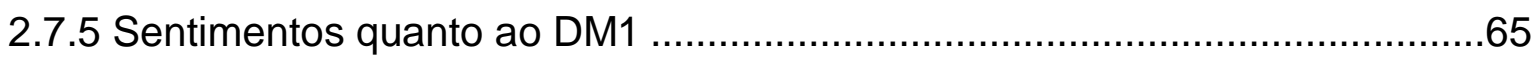

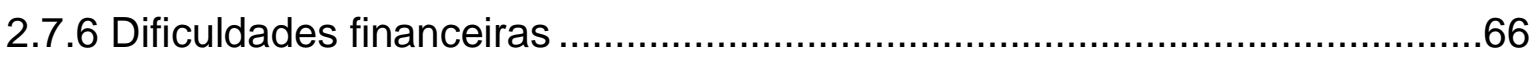

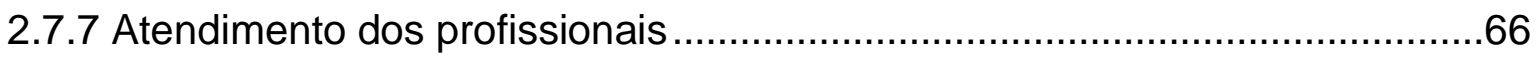

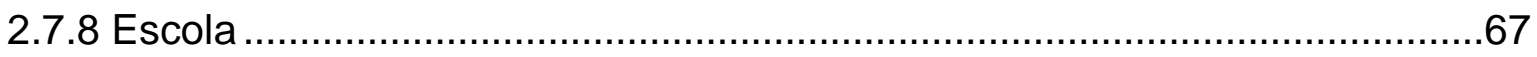

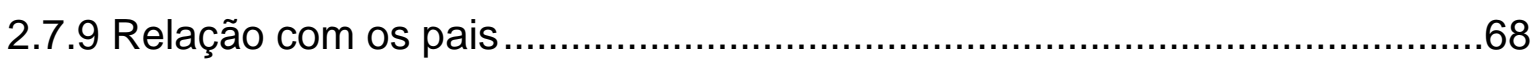

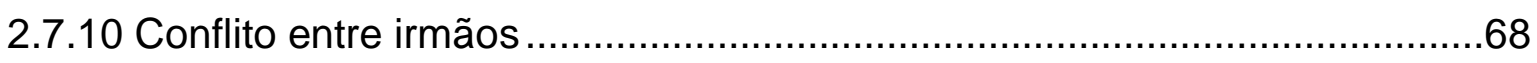

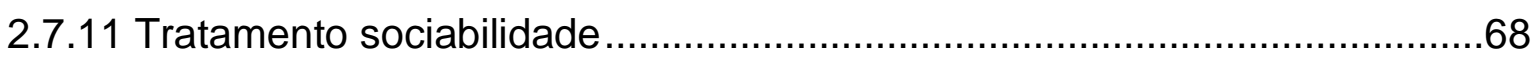

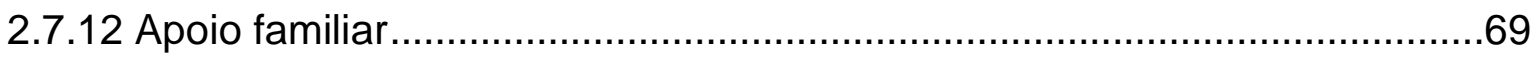

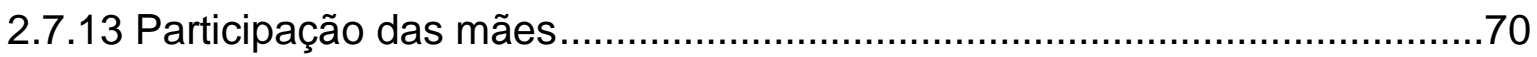

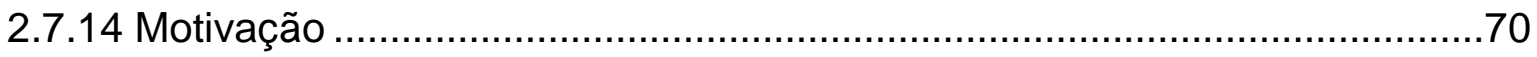

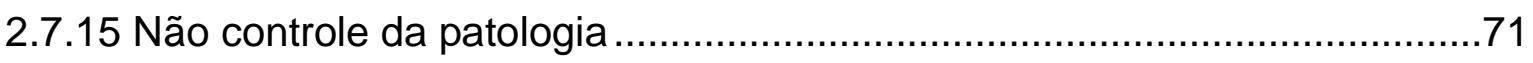

2.7.16 Fé religiosa

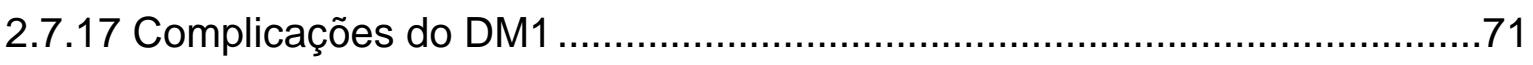

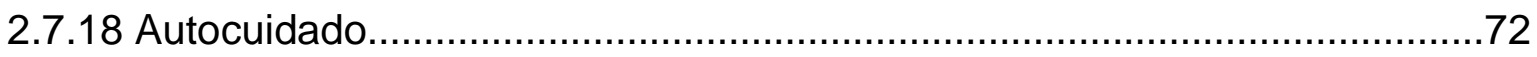

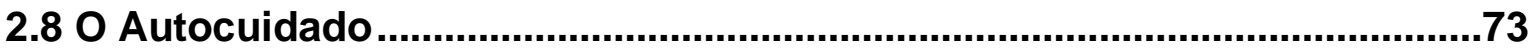

2.9 Projeto do Hospital das Clínicas ....................................................................78

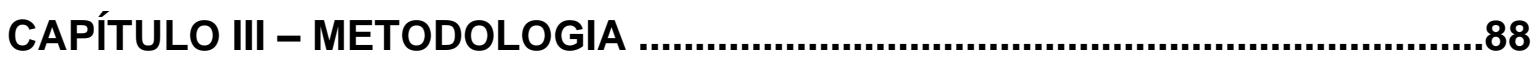

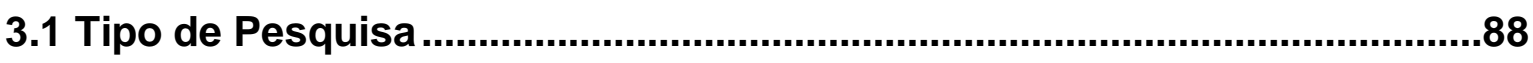

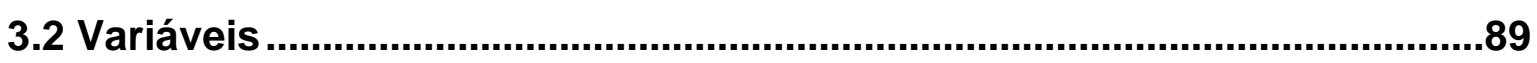

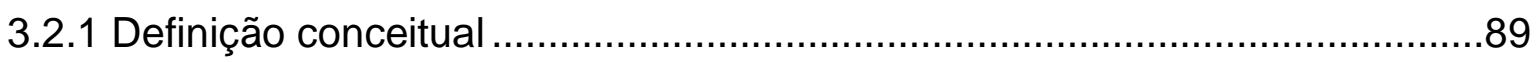

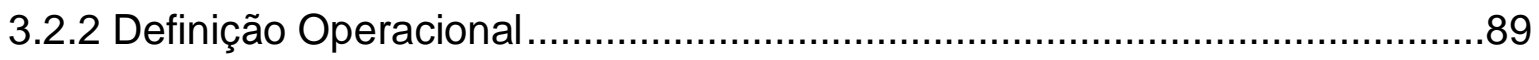

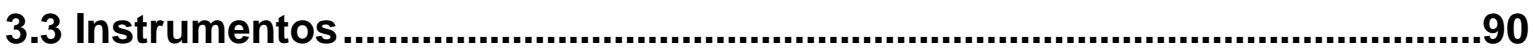




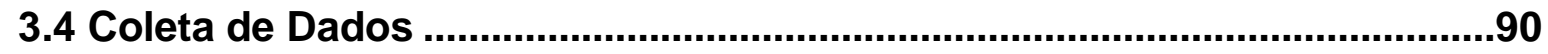

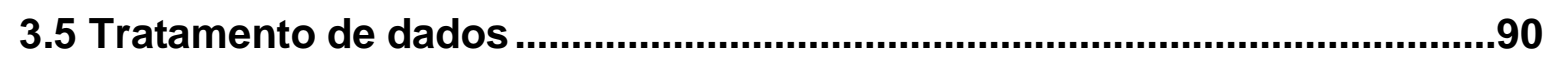

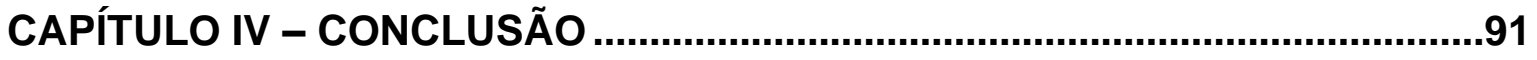

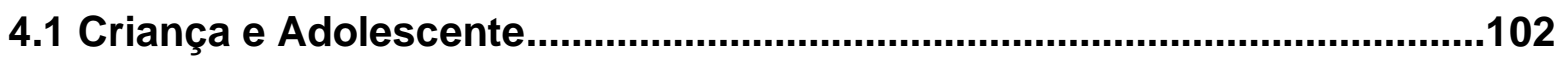

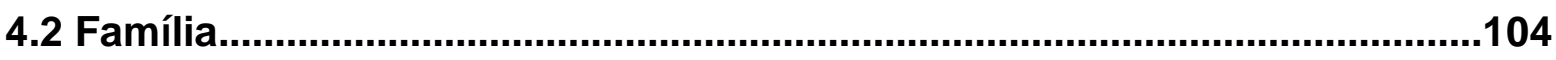

4.3 Educação e Equipe Multidisciplinar ...........................................................105

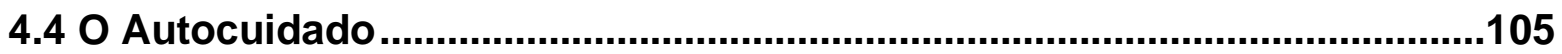

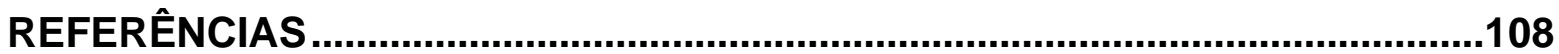




\section{INTRODUÇÃO}

Diabetes mellitus (DM) é uma doença crônica de ordem metabólica caracterizada por hiperglicemia e distúrbio do metabolismo dos macro nutrientes, devido à alteração da ação e/ou da excreção de insulina pelo pâncreas.

O diabetes mellitus, quando não mantido os níveis glicêmicos próximos à normalidade, pode levar a complicações altamente incapacitantes para a realização das atividades diárias e produtivas dos indivíduos.

A educação em saúde é fundamental para as intervenções preventivas no âmbito comunitário, particularmente no que se refere às doenças crônicas.

O paciente portador da doença possui uma extensa quantidade de informações que precisa aprender a administrar para que seu controle seja o melhor possível. O diabetes é uma doença que envolve fatores biopsicossociais e não somente físicos. No paciente com DM há várias questões a serem abordadas, como atividade física, plano alimentar, as limitações causadas pelas complicações do diabetes, o entendimento e utilização correta das medicações, nesse contexto faz-se necessária a intervenção de uma equipe multidisciplinar que reúna profissionais que atuem de forma integrada com o objetivo de proporcionar uma informação abrangente sobre a doença, cercando todas as peculiaridades relacionados ao diabetes tanto aos pacientes como a seus familiares.

A prática educativa, como parte integrante do cuidado, objetiva à construção de um saber compartilhado sobre o processo saúde-doença-cuidado. Através da elaboração e do fortalecimento da cumplicidade, a educação assegura aos indivíduos, o direito de decidir quais estratégias são mais apropriadas para promover, manter e recuperar sua saúde. 


\title{
CAPÍTULO I - O PROBLEMA
}

\subsection{Situação- Problema}

Diabetes mellitus (DM) é uma doença autoimune de ordem metabólica caracterizada por hiperglicemia e distúrbio do metabolismo dos macros nutrientes, devido à alteração da ação e/ou da excreção de insulina pelo pâncreas. Quando não mantido os níveis glicêmicos próximos à normalidade, pode levar a complicações altamente incapacitantes para a realização das atividades diárias e produtivas dos indivíduos. O diabetes é uma doença que envolve fatores biopsicossociais e não somente físicos (PINTO, 2012). "A classificação proposta pela Organização Mundial da Saúde (OMS) e pela Associação Americana de Diabetes (ADA) recomendada inclui quatro classes clínicas: DM tipo 1 (DM1), DM tipo 2 (DM2), outros tipos específicos de DM e DM gestacional" (DIRETRIZES SBD, 2014-2015, p.5).

Segundo a Sociedade Brasileira de Diabetes (2014-2015, p.5) O DM1, objeto do estudo,

está presente em $5 \%$ a $10 \%$ dos casos, é o resultado da destruição de células Beta pancreáticas com consequente deficiência de insulina. $\mathrm{Na}$ maioria dos casos, essa destruição de células beta é mediada por autoimunidade, porém existem casos em que não há evidências de processo autoimune, sendo, portanto, referidos como forma idiopática de DM1.

Segundo Torres et al (2003, p. 1040)

O diabetes mellitus é um dos mais importantes problemas de saúde na atualidade, atingindo a população como um todo e podendo surgir em qualquer idade. Suas repercussões, no que se refere tanto às incapacitações e mortalidade prematura, quanto aos custos relacionados ao seu controle e ao tratamento de suas complicações, reafirmam cada vez mais a necessidade de investimento em programas de educação em saúde.

No tocante a epidemiologia, a Sociedade Brasileira de Diabetes (2014-2015, p.1) ressalta:

\begin{abstract}
Atualmente, estima-se que a população mundial com diabetes é da ordem de 382 milhões de pessoas e que deverá atingir 471 milhões em 2035. Cerca de $80 \%$ desses indivíduos com DM vivem em países em desenvolvimento, onde a epidemia tem maior intensidade, com crescente proporção de pessoas afetadas em grupos etários mais jovens, coexistindo com o problema que as doenças infecciosas ainda representam.
\end{abstract}

A DM uma vez diagnosticada pode refletir em um choque psicológico e comportamental de extremo impacto familiar, principalmente em crianças e 
adolescentes. Geralmente a descoberta da DM em crianças se dá em um episódio de internação hospitalar devido ao caráter assintomático da doença ou o não relato imediato. Nesse primeiro contato da família com a DM, o processo de aceitação e convívio com a patologia exige atenção da família e o portador, pois é um momento de absorção de muitas informações. Primeiro é preciso cuidar, tratar o portador de diabetes em seu âmbito familiar esclarecendo dúvidas a respeito de complicações e mostrando a importância de um plano alimentar saudável. Na prática diária, será necessário e fundamental observar a higiene, os índices glicêmicos nas medidas, as dosagens e aplicações de insulina. O processo de adaptação e conhecimento da DM começa a partir da família, eles se tornam ferramentas de instrução para os portadores, deve-se ter agilidade no processo da educação em diabetes objetivando.

Além disso, é preciso que a equipe multiprofissional acompanhe a família para participar do processo de tolerância, adequação à doença, que requer diversos cuidados para manter o equilíbrio glicêmico e garantir êxito no tratamento. Adultos e adolescentes mostram mais autonomia para lidar com a DM do que as crianças, então o papel da família se torna ainda mais indispensável no diagnóstico e durante todo o processo para adquirir bons resultados. A capacitação dos pais pela equipe multidisciplinar os tornara aptos a prosseguir com as eventualidades. É importante envolver todos que participam da rotina ou das relações interpessoais, incluindo outros parentes para que todos conheçam os cuidados e saibam lidar com os processos que envolvem os pacientes com DM. Dessa forma o paciente terá mais segurança e prevenirá a sobrecarga dos pais. (BRINK, 2007).

A descoberta da doença cria situações embaraçosas que transcende a pessoa portadora da doença e sua família, que vivia uma rotina e hábitos até então consistentes e são obrigados a se adaptarem a uma rotina em que predomina a restrição alimentar A inserção de novos hábitos como exercícios físicos, consultas e rotinas metódicas, são mudanças que não ocorre do dia para a noite. Há um caminho a ser percorrido e repensado todos os dias ganhando contorno rítmicos apropriados para a manutenção boa da saúde. Na contramão, muitos portadores de DM passam a criar rejeições a certos alimentos e a acreditar em supostas ações nocivas ou proibidas ao uso e consumo de certos produtos. (PERES ET AL, 2007). Nesse sentido, é necessário compreender como os aspectos psicológicos sentimentos e comportamentos - podem interferir na motivação e na predisposição 
para a incorporação de mudanças no dia-a-dia, o que possibilitaria ao paciente conviver melhor com a diabetes. (BURGOS, 1999).

A nível mundial, existem esforços no sentido de se reorganizar o sistema de saúde para a resolução dos problemas apresentados pelos pacientes diabéticos. (MAZZE, apud ZANETTI ET AL, 2008). As ações de Educação em Saúde (ES) no Brasil têm, em suas raízes, estratégias de práticas em habilidades técnicas e práticas biologistas pouco participativas, que favorecem ações voltadas no sentido de um existir salubre, direcionadas para as classes populares, vistas como incapazes de iniciativas próprias para a continuidade da saúde pessoal e comunitário. (REIS; GOMES, apud FLISCH ET AL 2008).

Entende-se que a porta de entrada de intervenção com estes pacientes se dá a partir da Atenção Primária à Saúde (APS) que vem alcançando espaço significativo de discussão no cenário mundial como importante método para diminuir aquelas desigualdades de acesso a saúde. Representa o primeiro nível de contato dos indivíduos, com o sistema nacional de saúde, constituindo o primeiro elemento de um continuado processo de assistência à saúde, com serviços que têm em vista os principais problemas e necessidades de saúde da comunidade, proporcionando ações de promoção, prevenção e reabilitação da saúde. (MINISTERIO DA SAUDE, 2010). Os profissionais da APS estão mais próximos da comunidade e serão correia de transmissão para o combate a várias doenças como a DM. Entre as ações destes profissionais, se incluem ações educativas com portadores de diabetes.

Budó citado por Borba et al (2012, p. 170) ensinam que:

A prática educativa, como parte integrante do cuidado, objetiva a construção de um saber compartilhado sobre o processo saúde-doença-cuidado. Através da elaboração e do fortalecimento da cumplicidade, a educação assegura aos indivíduos, o direito de decidir quais estratégias são mais apropriadas para promover, manter e recuperar sua saúde.

A existência da verdadeira resposta ao tratamento e a qualidade do que atinge os seus objetivos estratégicos inclui habilitar qualificar a equipe multiprofissional de saúde para formar multiplicadores de educadores em diabetes englobando assim toda a comunidade que influenciada por suas condições sociais criem métodos e rotinas adequadas para que paciente de DM sinta-se confortável socioambientalmente as novas etapas que farão parte do seu cotidiano e a interdisciplinaridade ganha com a característica inovadora no saber. (SHAW, 2010) 
Além disso, a qualidade da comunicação entre profissionais e pacientes poderá ter importantes reflexos sobre a eficácia do tratamento, uma vez que o exercício do diálogo e da comunicação levará à melhor compreensão do problema e à melhor aceitação das orientações e recomendações, tão importantes no cuidar em DM. (ARAÚJO, 2010).

O paciente precisa apreender extensa quantidade de informações para que seu controle seja o melhor possível. Várias questões devem ser abordadas com pacientes portadores de DM1, como atividade física, plano alimentar, as limitações causadas pelas complicações do diabetes, o entendimento e utilização correta das medicações. Nesse contexto faz-se necessária a intervenção de uma equipe multidisciplinar que reúna profissionais que atuem de forma integrada com o objetivo de proporcionar informações abrangentes sobre a doença, cercando todas as peculiaridades relacionadas ao diabetes com pacientes e seus familiares.

$\mathrm{Na}$ tentativa de contribuir para a ampliação do conhecimento das ações na saúde, este estudo buscou na produção científica multiprofissional, no período de 2000 a 2015, as práticas educativas para indivíduos com diabetes.

Refletindo a realidade brasileira nos diversos níveis de atenção à saúde, e um pensar crítico da atuação da equipe multiprofissional de saúde, frente a esta clientela, elegeu-se como problema norteador da pesquisa: Quais as práticas educativas utilizadas pela equipe multidisciplinar de saúde, no processo contínuo de educação de crianças e adolescentes com Diabetes Mellitus tipo $1 ?$

\subsection{Principais Antecedentes}

De acordo com as buscas realizadas na biblioteca virtual em saúde BVS que hospeda bases de dados reconhecidas, dentre elas a literatura Latino-Americana e do Caribe em Ciências da Saúde (LILACS) e a Scientific Electronic Library Online (SCIELO) LILACS, são escassas evidências disponíveis, na literatura, que abordem sobre a educação em DM em crianças e adolescentes. 


\subsection{Delimitação do Estudo}

A busca dos artigos foi realizada de janeiro de 2015 a fevereiro de 2016, realizadas na biblioteca virtual em saúde (BVS) que hospeda bases de dados reconhecidas, dentre elas a literatura Latino-Americana e do Caribe em Ciências da Saúde (LILACS) e a Scientific Electronic Library Online (SCIELO) LILACS, e a e a Scientific Electronic Library Online (SCIELO). LILACS é um índice bibliográfico da literatura relativa às ciências da saúde e utilizou como descritores: Diabetes Mellitus, Educação em saúde, Diabetes Mellitus TIPO1, Equipe Multidisciplinar em saúde, para a busca dos artigos, foram utilizados descritores como indexadores da busca, em português e espanhol esses descritores foram submetidos a cruzamentos entre si na tentativa de encontrar a produção científica correspondente. Selecionados os resultados evidenciaram como portador de DM tipo1 em crianças e adolescentes a realização de ações educativas com a participação multiprofissional, a inclusão da família no tratamento e a realização de atividades em grupo. São poucos os estudos sobre a temática voltado para crianças e adolescentes. Destaca-se como limitação a carência de publicação. Foram separados 40 artigos dentre eles, mas somente 32 artigos foram utilizados. Temas relativos a crianças e adolescentes e a Diabetes Mellitus Tipo 1 propriamente dita e sobre a atuação da equipe multidisciplinar que engloba também a DM tipo 2.

\subsection{Justificativa}

Atualmente, existe aproximadamente oito milhões de pessoas com diabetes e um percentual de $5 \%$ a $10 \%$ desses pacientes apresentam a DM tipo 1 .

De acordo ainda com a OMS, a DM1 é uma das doenças crônicas mais preocupantes na infância, em contexto mundial, por apresentar incidência relevante nesta faixa etária. "A International Diabetes Federation (IDF) revela que mais de setenta mil crianças e adolescentes desenvolvem DM1 a cada ano". (CORREIA JR., 2014, p. 61)

Em relação ao diabetes tipo 1, não existe, ainda, formas de prevenção, embora, possa-se prevenir as complicações decorrentes do quadro crônico.

As intervenções médicas, através de exames e medicamentos, são insuficientes para controlar a doença, pois, tanto a dieta, como exercícios físicos e a 
situação emocional equilibrada, do paciente, têm influência significativa na doença, de modo que podem alterar e agravar o quadro patológico. Neste sentido: “... não basta ter consciência da doença e suas repercussões, pois a doença física atinge diretamente o emocional e este não é determinado apenas por aspectos conscientes". (MARCELINO e CARVALHO, 2005, p. 73)

Os pacientes com DM1 estão sujeitos a desenvolver a cetoacidose e apresentar variações no nível de insulina. Não é possível avaliar os autoanticorpos em todos os centros de referência disponíveis na rede de saúde, por este motivo "a classificação etiológica do DM1 nas subcategorias autoimune e idiopática nem sempre é possível. " (DIONÍSIO et al, 2011, p.45)

O diabetes mellitus está incluído na classificação de “... doenças metabólicas caracterizadas por hiperglicemia, associada a complicações, disfunções e insuficiência de vários órgãos, especialmente olhos, rins, nervos, cérebro, coração e vasos sanguíneos". (FIALHO et al, 2011, p. 146)

O período do diagnóstico do Diabetes Mellitus na criança é muito complicado para a família, fazendo com que a haja um corte do antes e depois da descoberta. Constata-se que ocorre uma mudança significativa no comportamento da criança e da família. É comum que a família sinta "culpa, medo, depressão e apatia, além de ameaçar a rotina. " (CORREIA JR., 2014, p. 61)

As relações familiares, a relação com os profissionais da saúde e toda a rede de apoio psicossocial contribui de forma significativa no autocuidado e no controle que o paciente deve ter com a doença. Compreender a criança de maneira global, aproximando- se do seu universo, contribui muito para que seja possível envolvê-la no cuidado com o manejo da diabetes. Nesta perspectiva, é possível também aprimorar a ação da equipe de enfermagem, a pesquisa, bem como a produção de novos conhecimentos sobre o tema "diabetes infantil".

Assim sendo, o apoio familiar e da equipe multiprofissional é muito importante para que a criança consiga se comportar de maneira harmônica diante do quadro patológico, compreendendo bem o tratamento, o conhecimento teórico e prático sobre o diabetes. Nascimento et al (2011, p.765) ressaltam que "A rede de apoio social, as relações familiares e a relação de confiança com os profissionais de saúde influenciamos comportamentos de autocuidado e autocontrole, além de aumentar a adesão ao tratamento, resultando na melhora do controle glicêmico". 
Nesse sentido, o presente trabalho busca reunir dados da literatura especializada sobre as dificuldades encontradas pelos portadores de diabetes Mellitus tipo 1 no enfrentamento da doença e seu tratamento a fim de obter subsídios para sugerir possíveis formas de intervenção pela equipe multidisciplinar de saúde.

\subsection{Objetivos}

\subsubsection{Geral}

Descrever as práticas educativas realizadas pela equipe multidisciplinar de saúde no processo contínuo de educação de crianças e adolescentes com Diabetes Mellitus tipo 1.

\subsubsection{Específicos}

Identificar os tipos de práticas educativas desenvolvidas pela equipe multidisciplinar em crianças e adolescentes com Diabetes Mellitus tipo 1.

Citar os tipos de práticas educativas desenvolvidas pela equipe multidisciplinar em crianças e adolescentes com Diabetes Mellitus tipo 1?

Especificar o conhecimento da equipe multidisciplinar de saúde, no processo contínuo de educação de crianças com Diabetes Mellitus tipo1?

Estabelecer os papéis da equipe multidisciplinar de saúde, na educação continuada de crianças com Diabetes Mellitus tipo 1?

Assinalar os resultados da atuação da equipe multidisciplinar de saúde, no processo contínuo de educação de crianças com Diabetes Mellitus tipo 1?

\subsection{Questões Investigativas}

Quais os tipos de práticas educativas desenvolvidas pela equipe multidisciplinar em crianças e adolescentes com Diabetes Mellitus tipo 1?

Qual o conhecimento da equipe multidisciplinar de saúde, no processo contínuo de educação de crianças com Diabetes Mellitus tipo1? 
Quais os papéis da equipe multidisciplinar de saúde, na educação continuada de crianças com Diabetes Mellitus tipo 1?

Quais os resultados da atuação da equipe multidisciplinar de saúde, no processo contínuo de educação de crianças com Diabetes Mellitus tipo 1?

\subsection{Alcance e Limitações da Investigação}

O processo de autocuidado da criança e do adolescente com diabetes envolve educação e prática com o objetivo de torná-los autônomos em relação à DM1.

Experiências profissionais mostram que essa clientela apresenta dificuldades manifestadas em ajustar o horário da primeira dose matinal de insulina, dificuldades para manutenção da dieta adequada, problemas sociais a falta de acompanhamento e ausência de um adulto para orientá-los e/ou acompanha-los. 


\section{CAPÍTULO II - MARCO TEÓRICO}

\subsection{Fundamentação filosófica da pesquisa}

Ao referir-se à Criança e ao Adolescente é indispensável uma breve explicitação. São etapas da vida do ser humano que demandam um cuidado especial para um crescimento e desenvolvimento dos mesmos, oferecendo um ambiente mais seguro.

Frente às questões tão cruciais para a criança e o adolescente, a Constituição Federal /88 (CF/88) determinou em seu artigo 24, inciso XV "a proteção à infância e à juventude". (ROSSATO ET AL, 2011)

E, em 2006, baseando-se na CF/88, editou-se o Estatuto da Criança e do Adolescente $(E C A)$, que tem como premissa básica a proteção à criança e ao adolescente.

Nas Disposições Preliminares, 0 art. $2^{\circ}$ do ECA considera criança "... a pessoa até 12 (doze) anos de idade incompletos, e adolescente aquela entre 12 (doze) e 18 (dezoito) anos de idade" (ROSSATO ET AL, 2011, p. 71).

Já para o Ministério da Saúde, a faixa etária considerada é de 0 (zero) à 9 (nove) anos e de 10 (dez) à 19 (dezenove) anos para os adolescentes, pois para o Ministério da Saúde devem ser atendidas as especificidades tanto na fase de crescimento quanto na de desenvolvimento da criança e o inicio da puberdade (MS, 2010).

Essas transformações estão diretamente ligadas à saúde tanto da criança quanto do adolescente. Na busca da dignidade da criança e do adolescente e da valorização da vida, a intervenção do governo foi primordial propiciando aos mesmos serem detentores de direitos como qualquer outro ser.

\subsubsection{Doença Crônica}

A doença crônica no tocante à criança e ao adolescente deve permear tudo o que os rodeia de forma a prepará-los para o processo de aceitação da doença e assim buscar estratégias para a efetivação do tratamento. 
Por doença crônica Pless e Pinkerton apud Almeida (2003, p.42) a definem como: “... uma alteração do estado de saúde que (1) interfere com o funcionamento quotidiano por um período superior a 3 meses num ano; ou (2) causa um período de hospitalização superior a 1 mês no ano; ou (3) ocorrência simultânea de ambas as condições".

A doença crônica exige um acompanhamento sistemático tanto da família como dos profissionais da saúde que trabalham na perspectiva de minimizar o avanço da patologia e os seus sintomas, contudo, ela pode persistir durante toda a vida da pessoa. Esse fato traz uma configuração na rotina do individuo, em razão da necessidade de dietas, medicações, exames, consultas medicas e até mesmo repouso em casa ou hospital. (MOREIRA E DUPAS, 2006).

A atuação dos pais no desenrolar de uma doença crônica, o DM1 é de extrema importância. Quando criança, os pais assumem a responsabilidade do cuidado, já quando este passa à adolescência, lhe é transmitido a responsabilidade quanto ao tratamento. Pode acontecer de que o adolescente não tenha competência para realizá-lo com eficácia. Tal situação pode ser devida a falha na comunicação entre os membros e em outra vertente a própria escolha do adolescente. (ALMEIDA E PEREIRA, 2011).

Inúmeras são as doenças crônicas que o individuo pode desenvolver, dentre elas a Diabete Mellitus, e mais especificamente a Diabete Mellitus Tipo 1.

\subsubsection{Diabetes Mellitus}

O Diabetes, de acordo com a definição do Ministério da Saúde (2004) apud Moreira e Dupas (2006, p. 26):

o diabetes é um estado hiperglicêmico crônico, acompanhado de complicações agudas e crônicas, que podem incluir dano, disfunção ou falência de órgãos, especialmente de rins, nervos, coração e vasos sangüíneos. É uma doença comum e de incidência crescente. Estima-se que em 1995 atingia 4\% da população adulta mundial e que, em 2025, alcançará a cifra de 5,4\%.

O Diabete Mellitus (DM) é uma doença crônica, autoimune que destrói as células beta pancreáticas, que são produtoras de insulina (SESTERHEIM ET AL, 2007). 
Para a Sociedade Brasileira de Diabetes (SBD, 2013-2014, p.5), a Diabete Mellitus pertence “... a um grupo heterogêneo de distúrbios metabólicos que tem em comum a hiperglicemia".

Ocorrem também alterações em sistemas orgânicos tipo: nefropatia, retinopatia, doença coronariana, insuficiência renal periférica, entre outros. (SESTERHEIM ET AL, 2007).

A Diabete Mellitus tornou-se uma epidemia ao longo das Décadas. Em 2002, o numero de portadores da DM perfazia um total de 135 milhões de pessoas, com projeção para 2030 de 300 milhões de pessoas.

Várias são as razões do aumento do número de portadores da Diabete Mellitus e entre elas: aumento da população, sedentarismo, obesidade, maior sobrevida de pacientes com DM e o envelhecimento populacional. (SBD, 20132014).

No Brasil, acredita-se que o aumento da DM é devido às mudanças no padrão alimentar, juntamente com a probabilidade da genética.

Com a destruição das células produtoras de insulina, as células beta pancreáticas, tem-se o Diabetes Mellitus Tipo 1, sendo esta uma doença crônica e autoimune.

\subsubsection{Diabetes Mellitus Tipo 1}

A Diabetes Mellitus Tipo 1 é uma das patologias mais importantes na fase pediátrica. $\mathrm{O}$ aumento entre crianças e adolescentes tem sido de $3 \%$ ao ano e na idade pré-escolar é de $5 \%$ ao ano em diversos países. (MARCON, 2009).

A DM tipo 1 pode ocorrer em qualquer época da vida do individuo, porém é mais frequente antes dos 20 anos. (SESTERHEIM ET ALL, 2007).

O aparecimento da DM tipo 1 ocorre de forma abrupta, sendo assim, o individuo através dos sintomas pode determinar a data do inicio da doença. (GROSS ET AL, 2001).

Esta existe de duas formas, quando há destruição das células beta é a autoimune e/ou tipo $1 \mathrm{~A}$ e a tipo $1 \mathrm{~B}$ que vem a ser a forma idiopática de causa desconhecida. (GROSS ET AL, 2001). 
$\mathrm{Na}$ forma autoimune esta presente o processo de insulite além da presença dos auto anticorpos circulantes; já na idiopática tanto a insulite quanto os anticorpos circulantes estão ausentes. (GROSS ET AL, 2002).

A incidência da DM tipo 1 em crianças menores de 05 (cinco) anos vem aumentando significativamente. (SBD, 2013-2014).

Sendo a DM1 uma patologia crônica e que atinge normalmente crianças e adolescentes, tem como tratamento: o controle metabólico, a dieta alimentar, as atividades físicas. (ALMEIDA E PEREIRA, 2011).

O controle metabólico incide na administração da insulina diariamente, corrigindo o descontrole do metabolismo. (ALMEIDA E PEREIRA, 2011).

O controle da doença se relaciona com o emocional, segundo Marcelino e Carvalho (2005, p. 76) “... uma vez que o diabetes exige um controle intenso para evitar complicações", pois o sentimento de ambivalência é presente no sentido de fazer o que deseja e o que deve ser feito.

Diversos estudos demonstraram que a DM tipo 1 tem ligação com a genética, porém o aumento desta patologia para os estudiosos tem relação com os fatores ambientais, tais como: a dieta, viroses, sedentarismo, obesidade, o que pode levar o individuo a desenvolver resistência à insulina e a autoimunidade antilhotas (DIB ET $A L, 2008)$.

A DM tipo 1 tem uma relação intrínseca com o emocional antes do aparecimento da doença, por tal razão os autores a consideram como uma doença psicossomática. E dentre as causas emocionais citam-se: as perdas, os traumas emocionais, problemas com a família, escolar entre outros. Explicam também que está presente na consequência da doença gerando sentimentos de baixa estima, negação, ansiedade entre outros. (MARCELINO E CARVALHO, 2005).

Para evitar que o individuo venha a desenvolver a DM é necessária uma atenção mais eficaz à saúde e esta forma é a prevenção.

No caso da DM tipo 1 são duas as formas: a prevenção primária, que baseia no aleitamento materno e não no uso do leite de vaca nos três primeiros meses de vida. Já na prevenção secundária é através do controle metabólico que se evitará as complicações crônicas. (SBD, 2013-2014).

Sesterheim, et al (2007) explicam que para a detecção e a prevenção da DM tipo 1, todos os fatores devem ser avaliados, por ser esta uma doença multifatorial. 
O Diagnóstico da DM na primeira infância possui alguns dificultadores tais como: “... A dificuldade do reconhecimento dos sintomas decorre do fato de que o aumento da diurese é mascarado pelo uso de fraldas e a sede se manifesta por choro ou irritabilidade, que são sintomas inespecíficos". (CALLIARIS E MONTE, 2008, p. 244).

O não controle e a não adaptação ao tratamento pode gerar complicações agudas, tais como: a hiper e a hipoglicemia à curto prazo. (ALMEIDA E PEREIRA, 2011).

A hipoglicemia e a cetoacidose (CAD) são consideradas as principais complicações ocasionadas pela DM tipo 1. Sendo esta última “... a causa mais comum de hospitalização e morte em crianças diabéticas...". (CASTRO ET AL, 2008, p.548).

\begin{abstract}
A cetoacidose diabética é um distúrbio metabólico grave que decorre fundamentalmente da falta relativa ou absoluta de insulina, em que a concentração de cetoácidos plasmáticos encontra-se acima de $3 \mathrm{mmol} / \mathrm{l}$. A glicemia normalmente está acima de $300 \mathrm{mg} / \mathrm{dl}$, e o pH, abaixo de 7,30. 0 estado de consciência dos pacientes varia do normal ao coma, e, neste caso, a concentração plasmática de bicarbonato é igual ou inferior a 9 $\mathrm{mEq} / \mathrm{l}$. A cetoacidose ocorre primariamente como resultado de alteração metabólica no fígado, músculo estriado e tecido adiposo. (SILVA E CHAGAS, 1999, p.639)
\end{abstract}

Gross et al (2002, p.20) ressaltam sobre a manifestação da cetoacidose: "A conseqüência da perda das células beta é a deficiência absoluta da secreção de insulina, o que por sua vez deixa os pacientes suscetíveis à ocorrência de cetoacidose, muitas vezes a primeira manifestação da doença”.

Almeida e Pereira (2011) salientam que se o tratamento metabólico e a adesão à terapia não forem executados pelos adolescentes de forma adequada e continuada, pode gerar implicações no sistema vascular, renal e visual, podendo afetar a qualidade de vida do mesmo.

\title{
2.1.4 A Criança
}

São vários os desenvolvimentos psicossociais que o ser humano passa. 0 primeiro deles é o da criança, infância.

Com as mudanças no mundo, a visão da criança veio-se modificando, e a Sociologia da Infância, passou a ver a criança, como poderosa, rica, construtora de conhecimentos, competentes e que possuem identidade e uma cultura. "A criança é 
reconhecida como um sujeito ativo, competente, com potencialidades a serem desenvolvidas desde o nascimento; sujeito que aprende e constrói conhecimentos no processo de interação social". (DAHLBERG, MOSS \& PENCE apud ANDRADE, 2010, p.66).

Nessa perspectiva depara-se com a infância, que vem ser uma construção social diretamente relacionada às relações sociais, portanto “... não há uma infância natural nem universal, nem uma criança natural ou universal, mas muitas infâncias e crianças". (DAHLBERG, MOSS \& PENCE apud ANDRADE, 2010, p.67).

Para tais autores, as crianças são atores sociais, pois constroem e direcionam suas próprias vidas, tem voz ativa e devem ser escutadas sendo inseridas nos diálogos e na tomada de decisões e complementam que “... as crianças contribuem para os recursos e para a produção sociais, não sendo simplesmente um custo e uma carga." (DAHLBERG, MOSS \& PENCE apud ANDRADE, 2010, p.67).

\subsubsection{O Adolescente}

O segundo desenvolvimento é a adolescência, que vem ser a transição da infância para a passagem para a vida adulta.

A Adolescência é um período mais complexo do que a infância, em decorrência de ser uma mudança abrupta no ciclo de vida de um ser humano. $O$ organismo se transforma rapidamente e tais mudanças são muito importantes, impactando em toda a vida biológica, social e psicológica do ser. (ALMEIDA, 2003)

Vários são as transformações pelo qual o adolescente passa: biológicas e culturais. Mudanças também ocorrem à nível familiar, nas relações sociais com amigos, escola, de acordo com a história vivida por cada individuo.

... os valores, atitudes, hábitos e comportamentos que marcam a vida de adolescentes e de jovens encontram-se em processo de formação e cristalização. Os valores e o comportamento dos amigos ganham importância crescente na medida em que surge um natural distanciamento dos pais em direção a uma maior independência. (MS, 2010, P.47)

No adolescente, as modificações hormonais provocam uma aceleração do crescimento, altera a massa corporal em proporções significativas, que na visão do autor, vem a ser a adolescência precoce que é conhecida como puberdade, pois “... 
o corpo da criança sofre modificações fundamentais, entre elas na vertente sexual". (ALMEIDA, 2003, p.35).

As variações fisiológicas são determinantes nas emoções dos adolescentes, principalmente no tocante as dimensões corporais que estão diretamente relacionadas à imagem corporal que o adolescente tem de si mesmo. Nesse momento, o esquema corporal infantil passa por reformulações, reconstruções. Tal reconstrução é um processo interpessoal nos relacionamentos interpessoais. Nesse sentido o período de adolescência deve ser permeado pela confiança e respeito entre os membros que o rodeiam. (CARVALHO ET AL, 2002).

É o momento de oportunidades e grandes desafios, devido o mesmo adentrar a esta fase com corpo e pensamento infantil e emerge nessa etapa uma mudança biológica, tanto na forma de pensar quanto no modo de lidar com o mundo. (ALMEIDA, 2003).

$\mathrm{Na}$ visão de Almeida (2003), na adolescência intermediária, ocorrem mudanças no adolescente no tocante a forma de pensar, propiciando uma maior capacidade de abstração. Devido as novas emoções, estas terão impacto direto no comportamento do mesmo.

Acontece também a descoberta da autonomia e as modificações no ambiente escolar que exige do adolescente novas reações. (ALMEIDA, 2003)

O desenvolvimento psicossocial observado na adolescência tardia apresentase muito importante, pois, nesta etapa rumo à vida adulta, o adolescente se vê provocado a lidar com a negociação e a adaptação, o que pode gerar um grande stress no individuo. (ALMEIDA, 2003)

A adolescência é um período bem propicio para se observar a interdependência entre os desafios e as oportunidades, bem como analisar os riscos de comportamento que podem ser nocivos à saúde. (ALMEIDA, 2003)

Holmbeck apud Almeida (2003) desenvolveu um contexto para melhor compreensão da evolução do adolescente. Nota-se neste um modelo biopsicossocial que trabalha as modificações que se apresentam em diferentes domínios da vida do adolescente, comparando ao seu contexto histórico. (ALMEIDA, 2003)

Em linhas gerais o quadro abaixo apresentado demonstra como as primeiras mudanças biológicas são importantes no desenvolvimento do adolescente, considerando o contexto interpessoal. (ALMEIDA, 2003) 
Quadro 1: Modelo de Compreensão do desenvolvimento do adolescente

\begin{tabular}{|c|c|c|}
\hline & $\begin{array}{l}\text { CONTEXTOS INTERPESSOAIS DE } \\
\text { DESENVOLVIMENTO DO } \\
\text { ADOLESCENTE }\end{array}$ & \\
\hline & $\begin{array}{l}1 \text { Família } \\
2 \text { Pares } \\
3 \text { Escola } \\
4 \text { Trabalho }\end{array}$ & \\
\hline $\begin{array}{c}\text { MUDANÇAS PRIMÁRIAS } \\
\text { DESENVOLVIMENTAIS DA } \\
\text { ADOLESCÊNCIA }\end{array}$ & & $\begin{array}{l}\text { PRODUTOS DO } \\
\text { DESENVOLVIMENTO DO } \\
\text { ADOLESCENTE }\end{array}$ \\
\hline $\begin{array}{l}1 \text { Biológicas/Puberdade } \\
2 \text { Psicológicas/Cognitivas } \\
3 \text { Redefinição Social }\end{array}$ & & $\begin{array}{l}1 \text { Realização } \\
2 \text { Autonomia } \\
3 \text { Identidade } \\
4 \text { Intimidade } \\
5 \text { Sexualidade } \\
6 \text { Adaptação Social }\end{array}$ \\
\hline & \begin{tabular}{l}
\multicolumn{1}{c}{ VARIÁVEIS MODERADORAS } \\
INTRAPESSOAIS/DEMOGRÁFICAS \\
1 Estatuto socioeconômico \\
2 Comunidade/Vizinhos \\
3 Estrutura Familiar \\
4 Etnicidade \\
5 Gênero \\
6 Resposta individual à mudança
\end{tabular} & \\
\hline
\end{tabular}

Fonte: Holmbeck apud Almeida, 2003,p.37-38.

Percebeu-se que as alterações na adolescência impactam diretamente no corpo, no pensamento, na vida social e no autoconceito. Todas essas mudanças tão importantes, em tão pouco tempo deixa o adolescente em situação vulnerável, naturalmente. (ALMEIDA, 2003)

O apoio familiar e dos colegas e amigos da mesma faixa etária, tornam-se fundamental para evitar o stress ocasionado por tantas mudanças internas e externas. Nesta linha, importante também, são as respostas do sujeito às necessidades de adaptação, que poderão ser menos ou mais positivas, sendo determinante para o processo da adolescência. (ALMEIDA, 2003)

A irritabilidade natural desse período pode ser agravada quando 0 adolescente apresenta uma doença crônica ou uma deficiência sócio - biológica. 
A patologia crônica é vivenciada pelo adolescente de forma diferenciada dos demais, pois alem das alterações significativas do período este juntamente com a doença poder gerar danos significativos, devido ao fato da doença crônica ameaçar e perturbar a sua independência. Neste momento, a dependência do adolescente, com os pais e os técnicos de saúde para o controle da sua nova condição, é um fato.

Nesse momento tão crucial desses seres (crianças e adolescentes) que se encontram em processo de crescimento e desenvolvimento da personalidade, de processo de aceitação social, ao depararem com um processo de adoecimento, questões emocionais vêm a tona, como no caso do Diabetes Mellitus Tipo I. Sentimentos de ansiedade, medo, insegurança ocorrem primeiramente nas crianças; nos adolescentes a limitação da doença causa conflitos, pois é neste momento que o mesmo tenta integrar a novos grupos sociais. (FIALHO ET ALL, 2011).

O diagnóstico de uma doença crônica repercute na vida do individuo de formas diferenciadas. No caso da criança e do adolescente estes terão reações devido à cronicidade da patologia, da formação da sua estrutura bem como dos aspectos psicossociais retratando a percepção e a adaptação da família ao novo contexto. (ALMEIDA, 2003).

Para uma boa adaptação à nova fase da vida, isto é, do adolescente portador de DM1, a presença da família é crucial para que o mesmo se adapte à patologia e as exigências que a doença e o tratamento the são impostas. (ALMEIDA E PEREIRA, 2011).

\subsection{Responsabilidade social do enfermeiro}

O processo saúde-doença tem passado por novas concepções devido a reestruturação das políticas no tocante a promoção da saúde, sendo este o eixo central da assistência, buscando assim “... ações integradas de saberes, profissionais e populares, nas instituições públicas, privadas e de organizações comunitárias". (BUSS apud TRENTINI ET AL, 2011, p.96).

Focalizando a enfermagem nas praticas do profissional está inserido a assistência/cuidado específicos a todos os envolvidos, isto é, aos pacientes, à família, aos grupos e a comunidade na busca de transformar uma realidade concreta. 
O cuidado segundo Silva e Lacava (2010, p. 54) “... visa assegurar a continuidade da vida do grupo e da espécie", com fins de garantir as funções vitais, as necessidades biológicas, psicológicas, sociais e espirituais.

Nessa concepção a humanização das relações entre pacientes e profissionais de saúde demonstra a compreensão do outro em todas as suas dimensões. Para tal a humanização segundo Trentini (2011, p.101) “... depende de mudanças no modo de pensar, de agir dos profissionais de maneira a valorizar a defesa da vida e, portanto, facilitem a materialização do funcionamento do sistema de saúde, especificamente da promoção da saúde como um todo".

A enfermagem como pratica social perpassa pelo processo de transformação. Nesse sentido o enfermeiro precisa “...desenvolver atitude crítica e reflexiva, no sentido de implementar ações que expressem a participação responsável e seu comprometimento social, assim o papel social do enfermeiro fica visível nas diferentes práticas e se expressa de diferentes formas". (SILVA E LACAVA, 2010, p.55).

Ao compreender a enfermagem como pratica social, na promoção da saúde é visualizá-la como uma profissão que tende a se transformar no dia-a-dia e incorporando suas praticas de manutenção, de restauração da dignidade do corpo do ser humano.

\subsection{Políticas públicas para atendimento a criança com Diabetes Mellitus}

A mudança desse contexto ocorreu na década de 1970, por meio de uma proposta de medicina comunitária que valorizava os aspectos preventivos da saúde. Nesse período, os profissionais de saúde incorporaram conceitos da pedagogia de Paulo Freire nas ações de Educação em Saúde. Isso resultou em uma relação menos vertical entre os profissionais e a sociedade nessas práticas. (REIS, apud FLISCH ET AL, 2014).

Consequentemente na tentativa de somar as relações interpessoais, em 1985 a Divisão Nacional de Doenças Crônico-Degenerativas do Ministério da Saúde propôs a formação de um Plano Nacional de Prevenção e Controle do Diabetes Mellitus, enaltecendo o atendimento ao diabético naquilo que é composto por mais de um elemento inter-relacionados de sua doença, com enfoque no atendimento primário (Brasil, 1986). (ZANETTI E MENDES, 2000). 
As propostas básicas para o programa de descentralização e regionalização de assistência ao portador de diabetes foram publicadas pelo Ministério da Saúde (1988) denominado de Programa Nacional de Educação e Controle do Diabetes Mellitus. Nesse sentido, Zanetti e Mendes (2000) ressaltam que atividades tais como: educacionais e de capacitação profissional, diagnóstico precoce bem como tratamento adequado com recursos necessários devem fazer parte do programa de descentralização e hierarquização da assistência ao portador de Diabetes.

O Ministério da Saúde (1993) apontou algumas dificuldades para a implantação de programa acima citado. Foram descritos pelos técnicos de saúde

... que a assistência dirigida a estes pacientes se encontra concentrada nos níveis secundário e terciário; que inexistem centros de programas de educação continuada para a qualificação de profissionais de saúde; dificuldades na obtenção de medicamentos; escassez de pessoal e insuficiência na qualificação de equipes multidisciplinares para 0 atendimento global do diabético. Além disso, a própria estrutura do Sistema Único de Saúde é pouco resolutiva e encontra-se em fase de organização. (ZANETTI E MENDES, 2000, p. 84).

A Portaria ํo 371, de 04 de março de 2002, no tocante à Atenção à Hipertensão Arterial e ao Diabetes Mellitus reza sobre as responsabilidades do gestor federal, das Secretarias Estadual e Municipal de Saúde. Quanto à Secretaria Municipal, de Saúde o Ministério da Saúde dispõe:

\footnotetext{
III - Das Secretarias Municipais de Saúde:

a - implementação em nível local, com apoio das Secretarias Estaduais de Saúde, do Cadastro Nacional de Portadores de Hipertensão Arterial e Diabetes Mellitus;

b - cadastramento dos pacientes e manutenção do Cadastro Nacional atualizado;

c - garantia de acesso ao tratamento clínico aos portadores destas doenças na rede básica de saúde;

d - participação nos processos de capacitação dos profissionais da rede básica para o acompanhamento clínico destas doenças;

e - implantação de outras ações de promoção de hábitos e estilos de vida saudáveis voltados para a melhoria do controle clínico destas doenças.

$\mathrm{f}$ - guarda, gerenciamento e dispensação dos medicamentos recebidos e vinculado ao Programa. (BRASIL, 2002)
}

Assunção et al citado por Santos et al (2011, p. 954) ressaltam que:

Os gestores públicos se deparam com uma serie de barreiras e deficiências no que se refere a atenção ao usuário com diabetes mellitus na rede publica de saúde no Brasil. Somente a promulgação da lei de proteção e amparo ao usuário com DM não garante a regulamentação e disponibilização dos recursos necessários para o tratamento da doença, tais como instrumentos 
e materiais para verificação da glicemia capilar no domicilio, medicamentos e insumos, de forma regular e equitativa para todos, bem como não assegura também a capacitação da equipe multiprofissional de saúde para 0 atendimento.

Ocorre nesse sentido uma falta de integração nos vários níveis de atendimento do sistema do portador de Diabetes Mellitus, na rede de saúde publica de saúde, alem da falta de preparação dos profissionais propiciando assim maior incidência de pacientes doentes em alguns serviços especializados. (ZANETTI E MENDES, 2000).

\subsection{Atuação e prática da equipe multidisciplinar e o papel de cada um.}

O binômio saúde-doença perpassa por inúmeras variáveis e dentre elas, o trabalho da equipe multiprofissional de saúde.

A educação em diabetes é bem diversificada, porem deve englobar aspectos educacionais e comportamentais juntamente com o contexto com o qual o paciente está inserido, além do suporte ao tratamento insulínico.

A International Diabetes Federation (IDF) ressalta que a meta principal da educação em Diabete Mellitus é de “...treinar o portador ... a fazer decisões efetivas em seu autocuidado". (IDF apud LEITE ET AL, 2008, p. 234).

Um ponto crucial para o portador de Diabetes Mellitus Tipo 1, é o Cuidado que tem como base a Prevenção de fatores de risco, que são subdivididas em três: a prevenção primária engloba o sedentarismo, hábitos alimentares, obesidade entre outros; a secundária é "...a identificação de casos não diagnosticados para o tratamento" e na terciária a intensificação de controle no combate as complicações agudas e crônicas. (PEIXOTO E SILVA, 2011, p. 75).

A prevenção tem o enfermeiro como o profissional imediato no tocante ao "cuidado humano" desempenhando seu papel de educador.

É dever deste profissional:

incentivar a equipe multidisciplinar no desenvolvimento de ações de promoção, prevenção, proteção e reabilitação da saúde em nível individual e coletivo, em que cada profissional deve assegurar que sua prática seja realizada de forma integrada e contínua com as demais profissões e nas instâncias do Sistema Único de Saúde (SUS). Além disso, o enfermeiro precisa utilizar e desenvolver a criticidade para analisar os problemas da sociedade e procurar soluções que estejam de acordo com a realidade de cada pessoa. (PEIXOTO E SILVA, 2011, p. 75). 
Nessa perspectiva os profissionais devem estar capacitados profissionalmente, integrados entre si além de dever possuir autonomia para um bom reflexo nas ações.

Nesse sentido, Simão et al (2013, p.6) ensinam que o processo de trabalho de um Programa deve ser:

... desenvolvido por meio do trabalho coletivo, com uma cooperação forçada pela divisão técnica do trabalho, onde cada membro da equipe desenvolve atividades inerentes a sua especificidade num fazer multiprofissional e com uma cooperação voluntária que ultrapassa os limites das disciplinas, buscando um olhar integralizado.

Para tal a enfermagem deve atuar juntamente com os outros profissionais, isto é, com uma equipe multiprofissional no tocante ao cuidado do paciente, utilizando de estratégias educativas com intuito de auxiliar o mesmo na motivação e na aceitação do processo e no desenvolvimento de hábitos saudáveis propiciando melhora na qualidade de vida.

Nesse sentido é primordial "o incentivo da educação em saúde por meio de uma equipe multiprofissional para possibilitar o planejamento de programas de atenção à saúde voltada para pessoas diabéticas”. (PEIXOTO E SILVA, 2011, p. 77).

A American Association of Diabetes Educator's (AADE) demonstra na tabela abaixo, as sete medidas de avaliação comportamental propõem como parâmetro de qualidade dos resultados com um programa de educação.

Tabela1 - Critérios para avaliação da eficácia do programa de educação

1 Pratica de atividade física regular

2 Mudança no habito alimentar

3 Boa adaptação psicossocial

4 Adesão ao esquema posológico da medicação

5 Automonitorização adequada da glicemia capilar

6 Redução do risco de complicações crônicas (melhora no controle glicêmico)

7 Capacidade do individuo de corrigir corretamente hipo e hiperglicemias.

Fonte: Leite et al (2008, p.235) 
Para que tal educação ocorra é necessário um planejamento com a participação de profissionais capacitados e engajados no desenvolvimento de estratégias educativas em prol do paciente de DM tipo 1.

A atuação à nível primário de atenção á saúde perpassa pela "... condução à adesão, ao tratamento e no incentivo à autonomia dos cuidados". (PEIXOTO E SILVA, 2011, p. 77).

O IDF e Harris e cols, apud Leite et al (2011, p. 236) propuseram um currículo de educação em Diabetes Mellitus dividido em quatro sessões podendo ser grupal ou individual.

Na primeira sessão é exposta uma visão global sobre a doença. Na segunda é abordada a importância da questão nutricional e a sua relação com a insulina. Já na terceira avalia-se os resultados dos testes de glicemia, bem como ensina “...sobre a prevenção da hipoglicemia e atividade física, habilidades de manejo durante quadros infecciosos ou doenças intercorrentes". A quarta sessão trata da relação entre a automonitorização e $\mathrm{HbA1c}$. Os autores verificaram que houve uma redução nos níveis de $\mathrm{HbA1c}$ em $73 \%$ dos envolvidos.

A realização da atividade em grupo é importante no sentido de promover mudanças no estilo de vida, sendo este mediado pelo enfermeiro e pelas atividades educativas em saúde. (PEIXOTO E SILVA, 2011).

Segundo Oliveira et al apud Peixoto e Silva (2011, p.79) ensinam que:

\begin{abstract}
As intervenções grupais realizadas no contexto de promoção do autocuidado às pessoas portadoras de Diabetes Mellitus, permite troca de experiências, compreensão da dimensão ampliada do problema, vivências positivas evidenciadas pelos fatores terapêuticos (instilação de esperança: melhora baseada na esperança; universalidade: o seu sofrimento não é único; oferecimento de informações: informações didáticas, aconselhamento ou orientações; altruísmo: sensação de utilidade, compartilhar problemas; desenvolvimento de técnicas de socialização: habilidades sociais; comportamento imitativo: aprendizagem por substituição; coesão do grupo: atração entre os membros; aprendizagem interpessoal: interação).
\end{abstract}

Tal intervenção grupal permite o dialogo e maior integração entre os pacientes e os profissionais no tocante a troca de experiências, de conhecimento, possibilitando mudanças no estilo de vida do paciente. (PEIXOTO E SILVA, 2011).

A aceitação da doença pelo paciente e pela família vai determinar a condução do tratamento. (DIONÍSIO ET AL, 2011).

A presença da família é de extrema importância devida possuir informações relevantes do paciente e na facilitação do autocuidado. (PEIXOTO E SILVA, 2011). 
No tocante à família, esta é imprescindível, pois, parte dela o suporte emocional, bem como adesão a novos hábitos alimentares, aos exercícios físicos, monitoramento da glicemia e de ser acompanhada pela equipe multiprofissional.

Um dos profissionais da equipe multiprofissional é o da Nutrição que irá adequar a alimentação devido a relação da Diabetes com o metabolismo de carboidratos, proteínas e gorduras.

A mudança nos hábitos alimentares é considerada o maior desafio para os pacientes (crianças e adolescentes). Nesse sentido, a participação da família é essencial para a motivação e o incentivo no consumo de alimentos essenciais e nas quantidades adequadas necessárias para o cuidado da patologia. Dionísio et al (2011, p. 46) ensinam que:

A alimentação da criança deve ter aporte calórico e nutricional adequado às
necessidades individuais, permitindo crescimento e desenvolvimento
normais. Deve ser suficiente para, ao lado do tratamento insulínico,
normalizar os níveis de glicose, prevenindo a hipoglicemia.

O cuidado que a DM1 necessita deve ser acompanhada por uma equipe multiprofissional, que deverão acompanhar sistematicamente os pacientes, com intuito de prevenir complicações da patologia; bem como os familiares no sentido de integrá-los ao tratamento. Tais atuações da equipe propiciam a autonomia do paciente na condução da doença e de um vínculo entre paciente, família e profissionais. (DIONÍSIO ET AL, 2011).

Na visão de Damelson et al apud Almeida e Pereira (2011) salientam que no tocante aos cuidados da saúde, a família abarca os três níveis da prevenção: a primária, a secundária e a terciária.

No nível da prevenção primária, Damelson et al apud Almeida e Pereira (2011, p. 59) explicam que a atuação da família incide no “...envolvimento em comportamentos protectores da acção de factores de risco ou na escolha de estilos de vida (nomeadamente de comportamentos promotores da saúde, como a alimentação)".

Petrie e Weinman apud Almeida e Pereira (2011) relacionam a prevenção secundária ao entendimento que é dado à doença e aos sintomas pela família, o que influi na busca de cuidados e da adesão ao tratamento que a patologia exige.

A prevenção terciária é tida como múltipla no tocante ao papel da família, pois, é ela que prestará cuidados ao paciente e consequentemente dando-lhe o 
suporte necessário ao tratamento adequado. (DAMIELSON apud ALMEIDA E PEREIRA, 2011).

Nesse sentido, o investimento nas ações educativas é essencial, pois reduz o custo da doença bem como na melhora do prognóstico.

Rickeim e cols apud Leite et al (2008) ressaltam que a melhora no controle metabólico pode ser tida tanto na educação individual quanto na grupal, porem na relação custo benefício, o aprendizado em grupo é mais efetivo. (LEITE ET AL, 2008).

O trabalho em grupo permite o compartilhamento dos sentimentos frente à patologia e deve ter objetivos específicos, adequando-o a faixa etária e tendo como foco a melhora da qualidade de vida dos mesmos. (DIONísIO ET AL, 2011).

A educação para crianças, segundo a International Society for Pediatric and Adolescent Diabetes (ISPAD), parte de alguns princípios que devem estar fundamentados:

na motivação (o desejo e a necessidade de aprender sobre a doença); no contexto (idade e maturidade); na interatividade (atividade interessante e lúdica); na significância (importância do assunto); na progressividade (do simples para o complexo, em etapas); no dinamismo (interativa e prática); no reforço (metas e solução de problemas); na reavaliação, na evolução e na educação sempre continuada. (ISPAD apud LEITE ET AL, 2008, p. 236).

O processo de trabalho do Programa é desenvolvido por meio do trabalho coletivo, com uma cooperação forçada pela divisão técnica do trabalho, onde cada membro da equipe desenvolve atividades inerentes a sua especificidade num fazer multiprofissional e com uma cooperação voluntária que ultrapassa os limites das disciplinas, buscando um olhar integralizado

Cada faixa etária recebe uma educação diferenciada devido a suas particularidades, na visão de Leite et al (2008). As crianças pré-escolares são normalmente dependentes dos pais na questão da alimentação, do uso da insulina, sendo fundamental o envolvimento familiar em tal processo.

Uma das grandes preocupações dos pais com a criança diabética na faixa etária de 01 a 03 anos, é com relação à hipoglicemia que pode levar ao coma, óbito, é necessário então a medição da glicemia.

Já no período de 03 a 07 anos as crianças devem ser estimuladas ao autocuidado, apesar de ainda não possuírem um desenvolvimento motor adequado para tal situação. 
O diagnostico de DM1, nas crianças de faixa etária de 8 à 11 anos, pode levar a quadro depressivo moderado e a ansiedade. Com o tempo, a depressão pode aumentar devido ao fato do não desaparecimento da doença e a ansiedade nos meninos tende a diminuir enquanto que nas meninas aumenta. (LEITE ET AL, 2008).

Nesta faixa etária com maior desenvolvimento motor, raciocínio lógico, as crianças já se encontram mais aptas para o gerenciamento da doença, na aplicação da insulina, no monitoramento da glicemia, podendo assim assumir as tarefas relacionadas à patologia com a ajuda dos adultos treinados e capacitados.

Tabela 2 - Importantes fases do desenvolvimento e seus efeitos no diabetes de crianças e adolescentes.

\begin{tabular}{|c|c|c|c|}
\hline $\begin{array}{c}\text { Estágios do } \\
\text { desenvolvimento }\end{array}$ & $\begin{array}{c}\text { Etapas do } \\
\text { desenvolvimento }\end{array}$ & $\begin{array}{c}\text { Manejo do DM1: } \\
\text { Prioridades }\end{array}$ & Papel da Família \\
\hline $0-12$ & $\begin{array}{l}\text { Desenvolvendo confiança } \\
\text { primeiramente com os } \\
\text { cuidadores. }\end{array}$ & $\begin{array}{l}\text { Prevenindo e tratando a } \\
\text { hipoglicemia. Evitando } \\
\text { flutuações extremas no } \\
\text { nível de glicose } \\
\text { sanguínea. }\end{array}$ & $\begin{array}{l}\text { Lidando com estresse. } \\
\text { Partilhando as tarefas para } \\
\text { evitar pais } \\
\text { sobrecarregados. }\end{array}$ \\
\hline 13- 36 meses & $\begin{array}{l}\text { Desenvolvendo } \\
\text { autonomia }\end{array}$ & $\begin{array}{l}\text { Prevenindo e tratando a } \\
\text { hipoglicemia. Evitando } \\
\text { flutuações extremas no } \\
\text { nível de glicose } \\
\text { sanguínea devidos à } \\
\text { ingestão incorreta de } \\
\text { comida. }\end{array}$ & $\begin{array}{l}\text { Estabelecendo um } \\
\text { calendário, limites e lidando } \\
\text { com crianças que não } \\
\text { cooperam com a dieta. } \\
\text { Partilhando as tarefas. }\end{array}$ \\
\hline $3-7$ anos & $\begin{array}{l}\text { Desenvolvendo iniciativa } \\
\text { em atividades e confiança } \\
\text { em si mesmo. }\end{array}$ & $\begin{array}{l}\text { Prevenindo e tratando a } \\
\text { hipoglicemia. Confiando } \\
\text { a outros cuidadores o } \\
\text { manejo do diabetes. } \\
\text { Reforçando } \\
\text { importância a } \\
\text { alimentação adequada. }\end{array}$ & $\begin{array}{l}\text { Tranquilizando a criança. } \\
\text { Trabalhando a culpa. } \\
\text { Educando } \\
\text { cuidadores sobre o manejo } \\
\text { do diabetes. }\end{array}$ \\
\hline $6-11$ anos & $\begin{array}{l}\text { Desenvolvendo } \\
\text { habilidades nas áreas } \\
\text { físicas, cognitivas, } \\
\text { artísticas e sociais. } \\
\text { Consolidando } \\
\text { autocontrole adequado da } \\
\text { patologia. }\end{array}$ & $\begin{array}{l}\text { Fazendo um regime de } \\
\text { diabetes flexível que se } \\
\text { adeque à rotina da } \\
\text { criança. Mostrando para } \\
\text { a criança a importância } \\
\text { de um autocontrole } \\
\text { adequado da patologia. }\end{array}$ & $\begin{array}{l}\text { Envolvimento dos pais na } \\
\text { automonitorização, } \\
\text { estimulando o autocuidado } \\
\text { e a educação na escola e } \\
\text { de outros cuidadores. }\end{array}$ \\
\hline $12-15$ anos & $\begin{array}{l}\text { Manejo das mudanças } \\
\text { corporais. Desenvolvendo } \\
\text { auto-identidade. }\end{array}$ & $\begin{array}{l}\text { Manejo do incremento } \\
\text { da insulina, necessária } \\
\text { durante a puberdade, } \\
\text { quando o controle } \\
\text { glicêmico pode se tornar } \\
\text { mais difícil. Preocupação } \\
\text { com a imagem corporal. }\end{array}$ & $\begin{array}{l}\text { Reorganizando papeis de } \\
\text { pais e filhos, prevenindo } \\
\text { conflitos familiares. } \\
\text { Observar sinais de } \\
\text { depressão, } \\
\text { comportamentos de risco, } \\
\text { transtornos alimentares. }\end{array}$ \\
\hline $16-19$ anos & $\begin{array}{l}\text { Estabelecendo uma } \\
\text { identidade após entrada } \\
\text { na faculdade, inicio da } \\
\text { vida profissionais, } \\
\text { questões sexuais e } \\
\text { afetivas. }\end{array}$ & $\begin{array}{l}\text { Transição para uma } \\
\text { nova fase. Integrando o } \\
\text { diabetes a um novo } \\
\text { estilo de vida. }\end{array}$ & 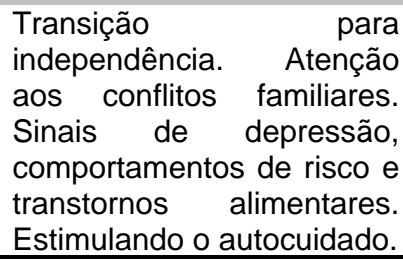 \\
\hline
\end{tabular}

Fonte: Leite et al (2011, p. 239). 
A participação das crianças nas tarefas escolares deve ser imprescindível, mas para tal a glicemia deve estar monitorada, que pode ser através de bombas de insulina ou canetas, sendo estes os modos mais seguros e aceitáveis pelos educadores. (LEITE ET AL, 2008).

$\mathrm{Na}$ adolescência o programa de educação deve abarcar questões tais como: a sexualidade, o estado emocional, drogas e questões pertinentes a própria doença. Nesse período, o adolescente já pode ser responsável pelo controle da doença, isto é, ser capaz de administrar a própria insulina, a automonitorização e a contagem de carboidratos, além da ajuda dos pais o que favorece em muito o tratamento.

Quadro 2 - Cuidados e orientações para a criança com diabetes na escola.

1. Informação à escola sobre o diabetes, o que é, os sinais e os sintomas e quais as causas de hipoglicemia.

2. Plano de cuidado deve ser escrito e conter quem realizara o cuidado, o local onde ficará o material e as instruções sobre como poderá ser feito o tratamento.

3. Administração de glucagon, instruir e apontar a pessoa responsável pela administração.

4. Mudança na rotina escolar: quando houver viagens ou festas, por exemplo, os pais devem ser avisados para providenciar o cuidado necessário.

5. Plano alimentar: a revisão de um programa básico de alimentos e refeições, devendo-se instruir a criança sobre as escolhas alimentares mais adequadas nas festas e lanches escolares, instruções sobre a contagem de carboidratos para calcular eventuais doses de insulina nos lanches e nas refeições.

Fonte: LEITE ET AL (2008, p. 238)

A incidência do desenvolvimento da depressão em adolescentes portador de DM1 é três vezes maior que a população em geral, gerando impactos em sua qualidade de vida. (LEITE ET AL, 2008).

Transtornos alimentares tais como: anorexia, bulimia podem ocorrer e afetar além do controle glicêmico o risco de morte precoce. (LEITE ET AL, 2008).

A área da saúde tem buscado inter-relacionar as diferentes áreas para propiciar ao paciente, no caso, o paciente crônico, melhora na qualidade de vida bem como o autocuidado. (DAMO ET AL, 2013) 
A participação da equipe interdisciplinar de saúde, no desempenho de suas atividades, além do tratamento da DM propriamente dito, isto é, deve incluir atividades voltadas para prevenção em todos os níveis: primordial, primária, secundária e terciária. (AMERICAN ASSOCIATION OF DIABETES EDUCATORS, 2008 apud COSTA E CASTRO, 2014, p. 31).

As competências dos profissionais segundo Costa e Castro (2014, p. 32-33) nas diferentes abordagens do paciente de DM são:

Participação da Medicina: diagnosticar a doença e as diversas intercorrências com ênfase na detecção precoce de complicações crônicas a ela relacionadas; avaliar clinicamente o paciente seja por demanda por parte do paciente ou por solicitação da equipe de saúde; elaborar plano de tratamento adequado para cada caso com prescrição apropriada da medicação; encaminhar pacientes e solicitar acompanhamento de outros profissionais médicos, quando necessário.

Participação da Enfermagem: acompanhar o tratamento dos pacientes; fornecer orientação sobre o DM e o uso adequado da medicação prescrita pelo médico com avaliação da interação de alimentos e/ou nutrientes com os diversos medicamentos; investigar a presença de lesões cutâneas nos pés; orientar sobre hábitos de vida pessoais e familiares, além da higiene pessoal; pesquisar fatores de risco e hábitos de vida inadequados à saúde.

Participação da Nutrição: realizar consulta de Nutrição elaborando anamnese alimentar e avaliando frequência, quantidade e qualidade dos alimentos consumidos; investigar intolerâncias e alergias alimentares; oferecer ensinamentos sobre o preparo e processamento dos alimentos; fornecer orientação alimentar em geral sobre a composição nutricional dos alimentos, rotulagem, etc.; prescrever e orientar a dieta, considerando aspectos socioeconômicos, culturais e ambientais; acompanhar a evolução nutricional de cada paciente.

Participação da Psicologia: realizar consulta psicológica com avaliação de como o paciente processa as informações quanto à saúde, para que o método de comunicação com ele seja devidamente individualizado; avaliar e tratar os aspectos emocionais que interfiram na qualidade de vida do paciente, seu nível de estresse e adesão ao tratamento global; atender familiares, para facilitar as mudanças de hábitos de vida do grupo familiar e a adesão ao tratamento.

Participação do Serviço Social: identificar aspectos socioeconômicos e familiares, visando caracterização da situação de trabalho e previdência; fazer o levantamento de expectativas sobre a doença e o seu tratamento; dar suporte ao paciente quanto a procedimentos de marcação de consulta, requerimento de medicamentos e outros serviços oferecidos pelo Sistema Único de Saúde; atualizar cadastro de recursos sociais visando o atendimento das demandas de pacientes e familiares, que possam interferir no tratamento da doença; desenvolver atividades visando à organização dos pacientes em associações de portadores da doença; realizar busca ativa de pacientes faltosos.

Participação da Educação Física: propor procedimentos para avaliar e acompanhar os níveis de aptidão física relacionada à saúde; programar e supervisionar atividades físicas para os pacientes, presenciais e/ou a distância, individuais e em grupos, adequando-as às realidades locais e às 
características específicas de cada indivíduo; programação e execução de projetos de atividade física para prevenção de outras doenças crônicas e complicações do diabetes; auxiliar no controle de algumas complicações do paciente diabético como vasculopatias e neuropatias.

Participação da Odontologia: realizar consulta odontológica, com avaliação clínica de cada paciente; orientar quanto aos cuidados de higiene oral e medidas preventivas com ênfase na prevenção da doença periodontal; encaminhar para tratamento odontológico especializado, sempre que necessário.

Participação da Farmácia/Análises Clínicas: realizar anamnese farmacêutica; realizar estudo farmacológico dos medicamentos em uso pelo paciente, com intuito de investigar interações medicamentosas; orientar o paciente e/ou cuidador sobre o uso adequado da medicação prescrita e possível interação entre os diversos medicamentos; orientar sobre cuidados específicos relacionados à realização dos diferentes exames laboratoriais complementares.

Participação da Fisioterapia: realizar consulta fisioterápica, com ênfase em distúrbios osteomioarticulares relacionados ao DM e ao pé diabético; investigar a presença de lesões que representem risco para o pé diabético; prevenir e promover a reabilitação de casos de neuropatia.

Participação da Comunicação: fornece assessoria na confecção de materiais educativos; auxiliar na realização de campanhas educacionais junto aos pacientes e à comunidade em geral; participar da divulgação de eventos voltados para a comunidade acadêmica ou para a população geral.

Além das participações específicas de cada área, existem atitudes comuns que devem ser adotadas e implantadas por toda a equipe interdisciplinar que vão desde o acolhimento do paciente no ambulatório até a assistência para o entendimento da conduta final, sempre visando a troca de informações.

\subsection{Definição do processo de educação}

\subsubsection{O Paciente: a quem devemos educar}

O Diagnostico de Diabetes Mellitus gera ao portador sentimentos tais como, o da negação, dificultando a compreensão e aceitação da patologia e das informações que the serão repassadas pela equipe multiprofissional (FISHER apud COSTA E CASTRO, 2014).

Zanetti (2007, p. 343) pontua quanto a diferença entre o conhecimento e o nível de informação: "...conhecimento é mais do que saber reproduzir uma informação, pois pressupõe modificação de atitudes, comportamentos e hábitos de vida".

Keers e Kherr apud Costa e Castro (2014) ressaltam que neste momento é imprescindível conhecer o indivíduo em todas as suas variáveis, isto é, 
personalidade, nível sócio cultural, crenças, grau de conhecimento da patologia, estilo de vida e as formas que o mesmo utiliza para enfrentar a doença. E complementam que a abordagem em formato de perguntas e respostas deve ser evitado, priorizando o dialogo e um ambiente propicio de ajuda mutua.

\subsubsection{Estruturação do conteúdo: o que educar}

Após a avaliação do grau de conhecimento e do histórico do paciente deve ser montado um programa de educação e este deve ser flexível para que se adapte as condições do paciente, do grupo e às vezes dos familiares. "Além dos pontos em comum, cada área poderá traçar quais são os pontos fundamentais a serem abordados para aprofundar um ou outro tema que seja necessário para cada grupo ou paciente, especificamente" (HARRIS apud COSTA E CASTRO, 2014, p.34).

As informações repassadas ao paciente devem estar em anuência com 0 estado do paciente. Num primeiro momento as informações primordiais e indispensáveis para a realização do tratamento é que deverão ser passadas ao paciente. No momento posterior serão adotadas outras medidas de acordo com o paciente. Portanto, o processo de educação deve ser paulatino, isto é, a cada fase vencida novos temas serão aprofundados no decorrer do tratamento. (COSTA E CASTRO, 2014).

Para tal é imprescindível o planejamento das ações, pois é tido como ferramenta indispensável para melhor alcance de resultados. "Este planejamento é primordial para que no dia do grupo ocorra a participação ativa do usuário na construção do conhecimento e na compreensão das orientações, assim como a identificação de suas limitações no processo educativo". (DAVID E TORRES, 2013, p.1189).

A Educação em Saúde (ES) está intrinsecamente relacionada à Promoção da Saúde. Estudiosos citados por Flisch et al (2014, p.1256) ensinam que a Educação em Saúde:

Apresenta-se como um campo de teoria e prática interdisciplinar, comprometido com a implementação e avaliação de processos educativos voltados para a promoção da autonomia, da participação e da postura ética, corresponsável e segura dos indivíduos e das comunidades diante de suas questões de saúde e de meio ambiente. 
$\mathrm{Na}$ busca de um resultado esperado da Educação em Saúde, tem-se a Atenção Básica, pois esta visa “... o desenvolvimento de uma atenção integral que impacte na situação de saúde e autonomia das pessoas e nos determinantes e condicionantes de saúde das coletividades". Na efetivação da Atenção Básica temse a Saúde da Família, "... que, nas atuais concepções, considera-se equivalente ao termo Atenção Primária à Saúde (APS)”. (FLISCH ET AL, 2014, p. 1256)

Nesse sentido pode verificar na figura abaixo, como a Educação em Saúde tem sido pensada, planejada e operacionalizada no âmbito da Atenção Primária da Saúde (APS). A Educação em Saúde:

é resultado de diversas dimensões inter-relacionadas, e, dentro de cada uma delas, os seus principais aspectos, que podem influenciar o alcance de seus resultados. Dentre esses aspectos estão os serviços de saúde, os quais envolvem políticas, programas, infraestrutura, materiais e a valoração de práticas educativas no cotidiano dos profissionais de saúde (FLISCH ET AL, 2014, p. 1256-1257).

É de suma importância a formação em saúde para o desenvolvimento de competências e de incorporação de concepções pedagógicas no campo da saúde além das parcerias entre comunidade e profissionais. (FLISCH ET AL, 2014).

Figura 1 - Aspectos da prática coletiva de educação em saúde.

Educação em Saúde

1 - Serviços de Saúde

a) Organização dos serviços de saúde

b) Políticas públicas de educação em saúde

c) Programas, ações e linhas de cuidado em Saúde Pública que incluem a educação em saúde

d) Infraestrutura, materiais pedagógicos

e) Valoração das práticas educativas em saúde

f) Percepção dos gestores e dos profissionais de saúde sobre educação em saúde
2 - Produção científica

a) História da educação em saúde - marcos e concepções hegemônicas

b) Elaboração de estruturas conceituais, concepções, processos, materiais e tecnologias

c) Relação teoria x prática
4 - Comunidade, ambiente e contexto

a) Nível de adesão/participação e valoração das práticas de educação em saúde

b) Contexto político, cultural, social e ambiental

c) Modos de viver, de ser saudável, de adoecer: percepções,

experiências

d) Nível de conhecimento em saúde

e) Aspectos econômicos e educacionais

Fonte: FLISCH ET AL, 2014, p.1257. 
A Educação Popular em Saúde (EPS) atualmente tem representado um espaço imprescindível para a troca de saberes, experiências e de propostas alternativas na melhoria dos serviços de saúde.

A política pública de EPS em vigor propõe a participação social como uma
diretriz nas ações educativas da APS. Essa perspectiva pressupõe a
participação de sujeitos sociais, ativos, criativos, transformadores e tem
como missão o apoio ao desenvolvimento de práticas que fortaleçam a
constituição desses sujeitos. (FLISCH ET AL, 2014, p.1256)

Nesse sentido os autores supracitados efetuaram um estudo com o objetivo de analisar as percepções e experiências em Educação em Saúde de profissionais da Atenção Primária da Saúde, no município de Contagem/MG, no âmbito da APS nas Unidades Básicas de Saúde.

Participaram do estudo os profissionais que atuam nas ESF, na sua composição mínima: agentes comunitários de saúde, auxiliares e técnicos de enfermagem, enfermeiros e médicos.

Foi utilizado um questionário composto por dez questões estruturadas e cinco questões abertas para o relato das praticas coletivas de Educação em Saúde desenvolvidas pelos participantes. No tocante ao nível de conhecimento e da fundamentação das práticas coletivas em ESC se encontra explicitado abaixo:

Tabela 3- Descrição do nível de conhecimento e da fundamentação das práticas coletivas de Educação em Saúde Coletiva, de acordo com a categoria profissional, Contagem, MG (2011).

\begin{tabular}{|c|c|c|c|c|c|}
\hline \multirow[b]{2}{*}{ Categoria } & & & \multicolumn{3}{|c|}{ Profissionais } \\
\hline & $\begin{array}{c}\operatorname{ACS~N} \\
(\%)\end{array}$ & $\begin{array}{c}\text { Nível Médio } \\
\text { enfermagem } \\
\mathrm{N}(\%)\end{array}$ & $\begin{array}{l}\text { Enfermeiro } \\
\quad \mathrm{N}(\%)\end{array}$ & Médico N (\%) & $\begin{array}{c}\text { Total N } \\
(\%)\end{array}$ \\
\hline \multicolumn{6}{|l|}{ Nível de Conhecimento* } \\
\hline Precisa melhorar & $65(765)$ & $16(72,7)$ & $11(55,0)$ & $10(66,7)$ & $102(71,8)$ \\
\hline Adequado & $20(23,5)$ & $6(27,3)$ & $9(45,0)$ & $5(33,3)$ & $4028,2)$ \\
\hline \multicolumn{6}{|l|}{ Referencial teórico** } \\
\hline Reprodução de grupos & $39(32,0)$ & $12(42,8)$ & $15(38,5)$ & $9(40,9)$ & $75(35,5)$ \\
\hline Livros de técnicas & $23(18,8)$ & $6(21,4)$ & $12(30,8)$ & $6(27,3)$ & $47(22,3)$ \\
\hline Intuitiva & $26(21,3)$ & $7(25,0)$ & $6(15,4)$ & $6(27,3)$ & $45(21,4)$ \\
\hline Não sabe responder & $24(19,7)$ & $1(3,6)$ & $2(5,1)$ & $1(4,5)$ & $28(13,3)$ \\
\hline $\begin{array}{l}\text { Concepções de Paulo } \\
\text { Freire }\end{array}$ & $5(4,1)$ & $1(3,6)$ & $4(10,2)$ & - & $10(4,7)$ \\
\hline Não há & $5(4,1)$ & $1(3,6)$ & & & $6 \quad(2,8)$ \\
\hline
\end{tabular}

*Excluídos 24 questionários sem essa informação. Valores de $p>0,05$ (não significativo - teste qui-quadrado de Pearson); ${ }^{* *}$ Fundamentação da prática coletiva de educação em saúde.

Fonte: Flisch et al, 2014, p.1260 
Segundo os resultados ficou demonstrado que, no tocante ao nível de conhecimento em práticas coletivas de Educação em Saúde, todos os profissionais envolvidos no estudo reconheceram a necessidade de aperfeiçoamento.

Somente $28,2 \%$ dos profissionais consideraram ter conhecimento adequado para o desenvolvimento das práticas de ES. Os enfermeiros apresentaram o maior percentual $(45 \%)$ de conhecimento satisfatório na área, seguida da categoria médica $(33,3 \%)$, em menores percentuais, os profissionais de nível médio de enfermagem (27,3\%) e os ACSs (23,5\%). (FLISCH ET AL, 2014, p.1259)

Baseando-se nos resultados acima quanto à necessidade de capacitação para o desenvolvimento das práticas, verificou-se que os Agentes Comunitários de Saúde (ACS) perfizeram um total de $76,5 \%$, já os médicos $66,7 \%$ e os profissionais de enfermagem um total de 72,7\%. (FLISCH ET AL, 2014).

Frente ao resultado obtido pelos autores, estes acreditam que:

pode sugerir que essa percepção diferenciada seja produto das diferenças na formação profissional nessa área e na valoração que cada profissional atribui à prática educativa. Ainda permanece ativa uma prática educativa pouco inovadora e, muitas vezes, afastada do conhecimento científico produzido nessa área e da política nacional nesse campo de atuação. (FLISCH ET AL, 2014, p. 1261)

A Educação em Saúde possui em seu cerne a educação propriamente dita, com vistas a promover aos profissionais da área maior autonomia, reflexão critica, propiciando meios de identificar e intervir nas questões de saúde e meio ambiente.

No processo educativo é fundamental que ocorram as trocas de saberes e de conhecimento para efetivo desenvolvimento do trabalho. (DAVID E TORRES, 2013).

A interdisciplinaridade possibilita o contato com diferentes estruturas, oferecendo condições do profissional de saúde perceber o homem como um todo, ultrapassando a especificidade de sua formação acadêmica, trazendo novas formas de cooperação e comunicação com os usuários, sobrepondo à valorização da concepção biológica do processo saúde e doença. (DAVID E TORRES, 2013, p.1190)

Nesse sentido tem-se a interdisciplinaridade que engloba as áreas sociais e humanas, tendo um olhar sobre o individuo em sua totalidade, isto é, quando há a troca de saberes que transcendem a área da saúde. (DAVID E TORRES, 2013). 


\subsection{Perspectiva das crianças com DM sua real dificuldade e os fatores que interferem na sua vida cotidiana.}

O diabetes mellitus tipo 1 (DM1) é a segunda doença crônica mais frequente da infância, menos prevalente apenas que a asma.

O desarranjo metabólico causado pela doença e a complexidade do tratamento, incluindo insulinização, plano alimentar, plano de exercícios, automonitorização e educação sobre a doença, tornam-se desafios nessa faixa etária. O impacto da doença sobre um organismo em formação deve ser levado em consideração em todos os aspectos do tratamento. Os objetivos não devem incluir apenas o bom controle da doença, mas um plano que permita crescimento e desenvolvimento adequados, evitando sequelas neurológicas e proporcionando um ambiente emocional saudável para o amadurecimento das crianças. (SOCIEDADE BRASILEIRA DE DIABETES - DIRETRIZES 2007).

A Diabetes Mellitus tipo 1 interfere nas relações familiares em todos os seus aspectos e consequentemente no tratamento da patologia. Tal situação gera sentimentos tais como: medo, insegurança, conflito e pode ocasionar também a superproteção ao filho adolescente atrapalhando o seu desenvolvimento a nível de personalidade. (CORRER, 2013).

Estudos apontam índices de incidência e prevalência do diabetes. Destaca-se o Projeto Multinacional para o Diabetes na Infância - DIAMOND. As pesquisas apontam uma frequência elevada do diabetes Tipo 1 em crianças, adolescentes e adultos jovens.

Em decorrência da necessidade de uma intervenção multiprofissional e interdisciplinar com o diabetes tipo 1, foi criado o Projeto DOCE (Diabetes Objetivando Controle e Educação) pesquisa desenvolvida por nutricionistas, endocrinologistas e psicólogos, votada para pacientes diabéticos tipo 1. "Tem por objetivo principal diminuir ou retardar o aparecimento de complicações crônicas da doença, aumentando a longevidade e melhorando a qualidade de vida". (MARCELINO E CARVALHO, 2008, p. 346).

O Projeto DOCE fez uma avaliação do quadro emocional das crianças com diabetes, relacionando com a doença, pensando na privação e controle que envolve a diabetes, considerando ainda, a modificação da rotina de uma criança com este diagnóstico. 
A população alvo foram 06 crianças, sendo 03 (três) do sexo masculino e 03 (três) do sexo feminino, entre 05 (cinco) e 11 (onze) anos de idade. Utilizou-se de técnicas projetivas, entrevistas com os pais e/ou responsáveis, que ocorre nos anos de 2001 e 2002.

Primeiramente foi feita uma avaliação individual utilizando-se do teste HTTP, pessoa, casa e árvore. Após foram utilizadas diversas técnicas projetivas, tais como: do desenho antes e após o diagnóstico; do encantamento que retrata sobre o bicho que o sujeito gostaria de ser; o da argila produzindo obras de como ele tem enfrentado a doença; o desenho da arvore que traz à tona os conteúdos mais profundos e os proibidos.

Utilizou-se também das artes visuais através do simbolismo de datas e sentimentos, tais como: páscoa, felicidade, natal, tristeza, amor e após a simbolização da representação da Diabetes Tipo 1.

Diante das respostas dadas pelos pacientes observou-se sentimentos dos mais variados, entre eles: desajuste, solidão, timidez, retraimento, morte, ansiedade, inquietação frente ao futuro, submissão, luto, privação alimentar, dependência do outro, desespero e dúvida.

Tais sentimentos, segundo os pesquisadores estão relacionados desde o diagnóstico, da vivencia da doença e amaneira pela qual estão encarando a mesma.

Moreira e Dupas para ter um melhor entendimento da criança que vivencia o Diabetes foi efetuado uma pesquisa no Centro de Especialidades, Unidade Pediátrica de um hospital de médio porte de uma cidade do interior do Estado de São Paulo e por indicação de crianças participantes. O período da entrevista foi de setembro/2001 a julho/2002, tendo como público alvo de 11 crianças de 07 a 12 anos de idade e 01 adolescente de 14 anos. A pesquisa utilizou de uma entrevista semiestruturada tendo como questão norteadora: "como é para você conviver com o diabetes?"

Fialho et al (2011) desenvolveram um estudo que teve como publico alvo, 15 (quinze) crianças e adolescentes atendidos no Polo da Criança e Adolescente Insulino Dependentes do Serviço de Controle de Hipertensão, Diabetes e Obesidade (SCHDO), da Secretaria Municipal de Juiz de Fora/MG. Tal estudo teve como objetivo demonstrar a percepção das crianças e adolescentes frente à doença. $\mathrm{A}$ questão que norteou foi: "Conte para mim a sua vivência referente à repercussão do Diabete Melittus no seu cotidiano”. (FIALHO et al, 2011, p. 147). 
Nesse estudo verificou-se que as questões levantadas pelos entrevistados foram em relação á restrição alimentar, uso da insulina e as limitações da doença na escola.

Vários estudos foram efetuados por diversos autores, com intuito de entender, ampliar e melhorar $\mathrm{o}$ atendimento às crianças e adolescentes portadores da patologia Diabetes Mellitus Tipo 1. Os resultados destas pesquisas serão inseridas no decorrer deste trabalho.

\subsubsection{Diagnóstico e a patologia}

Ao se deparar com uma doença a criança/adolescente sofre um grande impacto na sua vida, devido as mudanças que ocorrerão. O diagnóstico é um momento muito doloroso.

$\mathrm{Na}$ visão de Moreira e Dupas (2006), é um momento de tristeza, de sofrimento. A criança se mostra emocionalmente abalada. Sente medo, raiva, bem como tudo ou nada disso. Sente-se pisando em um terreno desconhecido. Os respondentes declararam:

(...) eu fiquei confusa, eu não sabia o que era diabetes.... Por que eu não podia comer o bolo ou o chá, o leite? Aí depois eu pedi para a enfermeira me explicar. E ela explicou de um jeito que eu não conseguia entender (Entrev. 4).

Eu sofri muito naquela época. Foi assim, do dia para noite que fiquei sabendo (Entrev. 7).

Segundo Moreira e Dupas (2006) alguns depoentes relataram que não entendiam sobre o funcionamento da doença, isto é, da causa, dos sintomas, das restrições entre outros.

Ah, geralmente eles dizem, os médicos e as pessoas que já conhecem, terapeutas, a A. já chegou a falar que minha diabetes é emocional, mas eu não sei muito bem o que quer dizer um diabetes emocional (Entrev. 4).

Não tenho idéia... Perda de funcionamento mesmo.... Não sei direito porque o pâncreas parou de funcionar (Entrev. 8).

Ah, eu acho que vem do sangue. Meu pai tem diabetes, é perigoso a gente pegar diabetes (...) Acho que é "modo" de sangue (...) É perigoso pegar porque ela 
(mãe) tem parente que tem diabetes também. Se não tem parente, daí não tem (Entrev.2).

\subsubsection{Reações corporais}

A Diabetes Mellitus traz em seu bojo mudanças significativas na vida do portador, pois a partir deste momento, este deverá estabelecer novas relações, isto é, com o seu corpo e com o mundo que o cerca.

As crianças/adolescentes relataram sobre o percurso da descoberta da doença, como sentiu seu corpo diferente e como foi percebido que algo errado estava acontecendo, segundo Moreira e Dupas, (2006).

Foi assim... Eu tava me sentindo muito mal. Eu desmaiava direto, ficava ruim, mole, com tontura, com tremedeira (Entrev. 7).

Com o tempo, a criança passa a identificar como o seu corpo reage frente a patologia, identificando as dores, as idas ao banheiro como relatam os pesquisados dos autores supracitados.

Ah, corpo ruim. Quando a diabetes sobe fico com o corpo ruim, dói as costas, dá uma canseira (Entrev. 2).

Quando ela tá alta dá vontade de ir no banheiro toda hora, toda hora beber água (...). Hoje eu tô mal. Ontem eu fui no banheiro, ontem à noite, hoje cedo fui 4 vezes no banheiro, desde ontem (Entrev. 2).

Quanto aos sintomas da doença, um dos entrevistados relata que não percebia os sintomas da doença, segundo Moreira e Dupas (2006).

Eu não sinto. No comecinho eu sentia. Eu tremia e sentia fome. Agora não, se eu tô passando mal alguém que vê, porque eu tô ficando branca. Se ninguém vê, eu também não percebo (Entrev.12).

2.6.3 Controle da alimentação e uso da insulina

As crianças com diabetes enfrentam mudanças e perdas significativas, em razão de uma doença crônica que demanda controles rigorosos de alimentação e glicemia. São submetidas à processo de picadas de ponta de dedo para se obter 
exames e aplicação de insulina, tornando-as diferentes das demais. (MARCELINO E CARVALHO, 2008).

Quanto ao uso da insulina para driblar a restrição alimentar as crianças/adolescentes relataram que:

[...] eu comia muito chocolate, né [...] Todo dia, todo dia, uma barra de chocolate [...] Eu tomo insulina [...] Tomo a NPH e a regular [...] Aí só com a insulina que abaixa, né? Aí, às vezes, eu tomo insulina mais do que ela recomendou, pra mim comer; daí dá para eu comer o que eu quero. Aí eu tomo a mais. (FIALHO ET AL, 2011).

Um dos sentimentos explicitados foi a da revolta com tantas limitações bem como obrigações que passou a ter que conviver no seu dia a dia, tais como o uso da insulina, segundo os pesquisados por Moreira e Dupas (2006).

E quando a revolta era com o diabetes, eu não queria tomar insulina, eu, todo doce que eu via na frente eu comia, eu falava: 'Isso não vai me fazer mal, isso é invenção da minha cabeça. Eu não tenho isso. Eu comia doce, eu ficava sem comer, eu não almoçava para ir para escola, não jantava em casa, não comia nada durante o dia (Entrev. 4).

Para Fialho et al (2011), uma das dificuldades encontradas pelos enfermeiros está ligado à restrição alimentar e a baixa adesão dos pacientes ao tratamento. No tocante á restrição alimentar, os entrevistados relataram que:

\footnotetext{
Eu não posso comer mais doce que eu gostava muito, né? É muito difícil [...] por causa que antes eu comia muito doce."; "A maior dificuldade para mim [...] Nossa! [...] Resistir às tentações dos doces [risos] muito difícil, muito difícil [...] Manter a glicose baixa, né [...]
}

Nas técnicas projetivas, no desenho dos animais aplicados às crianças e adolescentes, com relação ao sentimento de privação alimentar várias foram as projeções que puderam ser observadas “... o tubarão que come bastante, tem o desejo de comer carne". (MARCELINO E CARVALHO, 2008).

Segundo Moreira e Dupas (2006), quanto às dificuldades após a descoberta da doença, as crianças expõem sobre as limitações que a patologia determina nessa nova fase de vida. Uma delas é com relação à dieta alimentar.

Ah, segurar, resistir ao doce. Só isso que é difícil pra mim. Tomar insulina todo dia também (Entrev. 3).

Eu sempre gostei de doce na minha vida (Entrev. 8) 
Quanto à restrição alimentar e o sentimento de culpa devido ao desejo de comer foram relatados aos autores supracitados:

Às vezes eu vejo alguém comendo doce e eu falo: 'Ah, antes eu adorava isso, agora não posso mais comer'. Então, dá uma pontinha de vontade (Entrev. 4).

... Por não comer doce, só isso. Eu só me preocupava com doce (...) E eu acho que eu só me preocupo com doce, nem muito com a minha saúde (...) Eu não consigo superar essa vontade (Entrev. 8).

No tocante ao controle da doença com relação aos exercícios físicos, o uso da insulina Moreira e Dupas (2006), expõe os relatos dos entrevistados:

Só que eu não gosto muito de caminhar (...). Tipo, tem Educação Física na escola, aí eu faço. Só que à tarde, em casa mesmo, eu não faço muito. Assim, prá andar sozinha, aí eu não ando (Entrev. 8).

$A h$, no começo eu não queria. Eu chorava toda vez que ia fazer insulina, não queria. Mas agora, né, eu sei que tem que fazer, então eu faço (Entrev. 6).

A única coisa que eu não gosto muito é tomar insulina, às vezes você fica marcada, quando pega um vaso, estoura, aí fica roxo. E na barriga eu não gosto porque vai ficando bolinha... (Entrev. 8).

\subsubsection{Impactos emocionais}

Por enfrentarem uma doença crônica com impactos emocionais no tratamento, os pacientes diabéticos podem se beneficiar bastante com o trabalho da psicologia. Referindo-se a pacientes infantis, os benefícios podem ser ainda maiores, uma vez que é na fase da infância e da adolescência que se molda a "personalidade do individuo". (MARCELINO E CARVALHO, 2008).

A criança com diabetes passa por várias limitações, e a cada negativa, um sentimento novo, estranho. O rompimento com aquilo que traz conforto pode despertar sentimentos de medo, insegurança, raiva. Considerando que o "corte" é constante e os conflitos emocionais também, a depressão se faz presente significativamente entre os adolescentes que apresentam a Diabetes Melittus Tipo 1, provocando conflitos pessoais, familiares e sociais. (MOREIRA E DUPAS, 2006).

Segundo Marcelino e Carvalho (2008), os sentimentos declarados pelos pesquisados para o antes e o depois da doença foram bem antagônicos. Na técnica 
de desenho, no antes desenharam: "um copo de água", simbolizando a sede. Já no depois desenhou o contorno de uma copa de árvore relatando a tristeza e o vazio da alma, além de demonstrarem, o sentimento dos pais de desespero e dúvida. (MARCELINO E CARVALHO, 2008).

"[...] um dia cheguei em casa triste, porque teve festinha no colégio e muitas coisas não pude comer [...] no início chorava muito quando alguém comia alguma coisa na minha frente [...] mudou muito a minha vida e para pior. " (FIALHO ET AL, 2011).

No tocante ao medo da morte, foi relatado que "viver pro resto da vida, ou seja, 250 anos". (MARCELINO E CARVALHO, 2008). Em contrapartida demonstrar a superação do medo da morte, as crianças desenharam animais selvagens e fortes como o rinoceronte e hipopótamo, além de desenhos de super-heróis que denotam força e poder.

Marcelino e Carvalho (2008) relatam que foi demonstrado também força e poder quando os pacientes no desenho do HTTP fizeram uma pessoa com cabelo denotando no aspecto positivo: força, poder e virilidade, já no aspecto negativo: luto e submissão.

Segundo Moreira e Dupas (2006) a convivência com o Diabetes pois este gera o sentimento de angústia, a incerteza, o medo da morte e da dúvida quanto à cura da mesma. Os respondentes declararam:

A gente tem medo de morrer, gente que tem diabetes. Porque umas pessoas que têm diabetes já morreram. Se comer muito doce...(Entrev. 5).

Se eu estou em dúvida se eu posso comer ou não comer, eu sei que se eu puder comer não vai fazer mal. Se eu não puder e eu comer, sei lá, pode trazer algum prejuízo. Então eu prefiro saber primeiro, tirar a dúvida (Entrev. 4).

Moreira e Dupas (2006) relatam sobre quando a criança passa a perceber as limitações que o Diabetes Melittus Tipo 1 gera em sua vida diária.

Ah, eu andava muito de bicicleta, corria. Agora não, cansa, cansa mais rápido. É cansativo, entendeu? Às vezes quando eu ando de bicicleta a perna começa a ficar mole, eu paro. Correr também. Eu corria bastante. Agora diminuiu a velocidade... Eu não consigo correr, não tenho mais tanta força como eu tinha. Fico cansado (Entrev. 6). 
Antes eu ia em todo lugar e podia fazer as coisas. Agora eu não posso mais (Entrev 2).

Eu queria sair ontem com meus amigos... minha mãe não deixou porque meu diabetes estava alterado (Entrev. 3).

Segundo Marcelino e Carvalho (2005) o Diabetes Melittus é uma doença multifatorial, isto é, são vários os fatores que podem desencadear a patologia: os hereditários e os fatores externos como: traumas, perdas entre outros.

O adoecimento possui um fator negativo, pois a pessoa se sente invadida e sentimentos como inferioridade, depressão, medo, raiva, suicídio entre outros vêem à tona.

$\mathrm{Na}$ anamnese de adolescentes diabéticos, E.P.Stein e V.Charles (1971) verificaram perdas parentais (morte, separação, divórcio) ou distúrbios familiares graves em uma proporção significativamente elevada, o que, segundo eles, justifica a hipótese de que um indivíduo fisiologicamente sensível, em um clima de estresse afetivo, é mais susceptível a desenvolver manifestações clínicas do diabetes (AJURIAGUERRA, apud MARCELINO E CARVALHO, 2005, p. 73)

Consequentemente o novo quadro de saúde demanda uma readaptação do individuo no meio em que vive e exige por outro lado mais atenção da família e da sociedade. Como efeito negativo, o diabetes pode provocar "isolamento social e emocional" (MOREIRA E DUPAS, 2006, p.26).

No desenho da casa, Marcelino e Carvalho (2008) explicitam que as crianças demonstraram mecanismo de defesa frente à doença, em que ficarão evidenciados sentimentos como retraimento, timidez denotando inadequação social. No desenho as casas encontravam-se com a porta fechada e/ou pequena.

Segundo os autores supracitados, a Diabetes Tipo 1 pode ocasionar retardo no crescimento o que gera sentimentos de inadequação e inferioridade, como explicita um dos entrevistados: "Ficar maior que o pé do feijão do João do feijão".

Ao descobrirem sobre a doença, Marcelino e Carvalho (2008) relatam que um dos sentimentos que foram expressos pelos pesquisados foi o da solidão que apareceu em diferentes técnicas, conforme relatado abaixo: "Eles vivem no fundo do mar, escondidos nas profundezas". (técnica do animal). 
Um outro sentimento relatado, segundo os autores foi o do isolamento devido ao preconceito e com isto a criança/adolescente não divide a sua angustia com os outros.

Sei lá. Assim... as pessoas não entendem direito o que é, às vezes. Aí você tem que ficar explicando, elas ficam perguntando; mas isso era assim bem no comecinho, agora nem tanto. Mas eu procuro não falar, eu não falo. Assim, as pessoas que sabem que eu tenho sabem, mas eu procuro não falar prá ninguém ... eu acho melhor (Entrev. 8).

Tem só um que sabe, mas eu falo pra ele não falar pra ninguém (Entrev. 2).

Ajuriaguerra apud Marcelino e Carvalho, 2005 ensina que a Diabetes Mellitus interfere no processo cognitivo e esta apresenta diferenças no Q.I dependendo da faixa etária em que apareceu a doença, isto é, o Q.I, das crianças que desenvolveram a Diabetes antes dos 05 (cinco) anos de idade são bem diferenciadas das que a doença apareceu após os 5 (cinco) anos de idade.

Das limitações impostas pela doença no convívio escolar as declarações foram, segundo Fialho et al (2011): "De vez em quando, eu passo mal no colégio [...] Aí eu falo com a diretora, a diretora me deixa ir embora. Aí elas me levam na casa da minha vó."

\subsubsection{Dependência dos pais e transgressão}

Para Fialho et al (2011) a Diabetes reflete de formas diferenciadas na vida da criança quanto na do adolescente.

Na vida da criança, a doença é uma limitação na vida social, física, o que não permite às mesmas viverem a infância como qualquer outra criança não diabética. Tal situação afeta também a dos familiares. Para conseguir transpor os obstáculos frente à doença, a família deve compreender a dinâmica da doença bem como saber conviver com a criança afetada pela doença, a fim de transformar as dificuldades em aceitação e no autocuidado, o que é imprescindível para a melhora da criança. (FIALHO ET AL, 2011).

Marcelino e Carvalho (2008) explicam que a Diabetes Tipo 1 demanda cuidados específicos e no caso de crianças, muitas vezes são os pais que administram tais cuidados, o que pode ocasionar uma dependência, que para as 
crianças é mais um sentimento ao qual elas tentam lutar contra. Nos desenhos dos animais essa dependência pode ser observada ao relatarem: " o desejo do cavalo é ficar solto por aí"; "o desejo do cavalo é correr".

Segundo os pesquisadores tais desejos podem demonstrar “...protestos contra a dependência dos pais e/ou contra o controle exacerbado da doença, que os fazem sentir-se presos e sufocados". (MARCELINO e CARVALHO, 2008, p.349)

Nesse momento há uma mudança na dinâmica familiar, pois devido a exigência dos cuidados que o diabético tem que ter, os pais superprotegem o filho pelo medo da perda e gera alguns sentimentos como Ajuriaguerra citado por Marcelino e Carvalho (2005, p. 75)

... observa-se nessas crianças uma instabilidade de humor com
irritabilidade, além de uma imaturidade afetiva que se traduz por grande
necessidade de proteção, vontade imperiosa, falta de confiança em si e
uma dependência prolongada em relação a um ou ambos genitores.

Para Fialho et al (2011), no tocante ao adolescente, o diabetes atinge outros níveis, pois é nesse momento que o mesmo busca a independência com relação aos pais, maior autonomia e de repente se deparam com limitações, provocando sentimentos de rebeldia quanto à autoridade dos pais interferindo diretamente no tratamento da doença. E ressalta ainda que é neste momento que a diabetes para o adolescente tem um outro aspecto, a transgressão, delineando a maneira como o mesmo lida com as restrições alimentares e ao consumo de álcool.

Por ser um momento de novas relações sociais para o adolescente, este ao lidar com a doença e não a aceitar, por ter que mudar o seu estilo de vida frente aos seus amigos, ele utiliza da transgressão, conforme exposto por Fialho et al (2011) da resposta dos pesquisados:

"Ah! Eu não consigo, não consigo, porque eu vejo os outros comendo, e eu fico com vontade também de comer [...]"; "Eu não posso comer mais doce, que eu gostava muito, né [...] mas de vez em quando eu como."

\subsubsection{Ambivalência}

A Diabetes demanda um tratamento médico com rigor para evitar complicações séria tais como a cetoacidose. Tal situação gera sentimento de ambivalência nas crianças e adolescentes e para Ajuriaguerra a criança torna-se 
escrava da doença, “... pois o paciente diabético tem que estar sempre se fiscalizando, controlando a alimentação, a contagem de carboidratos, a glicemia, a aplicação de insulina" (HARTMANN et al apud MARCELINO E CARVALHO, 2005, p.74).

No desenho da figura humana, segundo Marcelino e Carvalho (2008), explica que quando os pés foram desenhados em direções opostos, estes demonstraram que estavam vivenciando também o sentimento da ambivalência. Pois tal sentimento denota o conflito entre o controle dos desejos e a impulsividade, sendo esta ultima um dificultador da doença frente a questão alimentar e do uso da insulina.

A alimentação controlada, exigida para evitar complicações da doença, pode trazer esta ambivalência de sentimentos, fazendo com que a criança, por um lado, tenha o desejo de comer doces, tão presente na infância, e por outro, precise controlar este desejo. Isto é revelado também na produção em argila quando falam da dificuldade em resistir aos doces, em conter a impulsividade do desejo de sentir prazer ao comer (HARTMANN et al apud MARCELINO E CARVALHO 2008, p. 348).

\subsubsection{Não aceitação da doença}

Para Marcelino e Carvalho (2005) o diabetes sofre influência do estado emocional do individuo e para tal deve ter um acompanhamento psicológico. E ressalta que a não aceitação da doença impede um bom controle da mesma

A não aceitação gera um conflito para o diabético e consequentemente um aumento da glicemia. Nesse sentido Fialho et al (2011) colocam que os entrevistados relataram:

"O mais difícil é o controle da glicemia, porque o emocional influencia muito. O que influencia não é só a dieta em si, lógico que ela é mais de 50\%, mas o emocional influencia também."

"É porque eu fico muito nervosa e tem muita coisa pra me preocupar e aí descontrola."

“É por causa do diabete, problema de família [...] aí eu fico desse jeito. "

Sendo a diabetes uma doença que altera a vida do individuo, pode gerar sentimento de raiva, desespero, de negação da própria doença entre outros. Para os 
pesquisadores supracitados, os entrevistados utilizaram do eufemismo para minimizar e de certa forma negar a própria doença, conforme relatos dos entrevistados.

“Ah! Eu não queria ter. Eu não queria ter, mas eu tenho. Fazer o que, né? É como se fosse um resfriado. Cuido. Tem dia que está alto, tem dia que não está. Mas vai vivendo".

"E outra coisa que eu gosto bastante de frisar é que eu não sou uma pessoa diabética, sou uma pessoa que tenho diabetes. Igual gripe, você tem gripe, você não está gripe. A gripe não é uma característica sua. "

"[...] mesmo sabendo que eu tenho, eu fazia a mesma coisa que eu fazia antes, comia de tudo também. Eu não aceitava não [...]. Agora eu não faço dieta, não faço nada não, continuo a mesma coisa [...]"

Fialho et al (2011) complementam que apesar de utilizarem um dos mecanismos de defesa: o processo de negação este vem como um dificultador, podendo gerar complicações, pois o estado emocional está ligado diretamente ao tratamento.

\subsubsection{Convivência com a doença}

Por ser uma doença que não tem cura e ainda com possibilidade de complicações crônicas, o paciente com diabetes precisa ser acompanhado sistematicamente, através de um rigoroso controle glicêmico, bem como a exames médicos periódicos. Contudo, existe a necessidade, ainda, de que o paciente tenha uma boa alimentação, faça atividades físicas e tenha amparo emocional, porque este conjunto de fatores impacta diretamente no controle glicêmico, podendo o contrário ocasionar a piora do quadro patológico, segundo Marcelino e Carvalho, (2008).

Segundo Moreira e Dupas (2006) os pesquisados relataram como é conviver com uma doença que tem tratamento e não tem cura:

Ah, é difícil mesmo. Saber que tem que conviver com isso o resto da vida, parar de comer doce, vou acostumando, já vai fazer 3 anos. Eu vou me adaptando... (Entrev. 7). 
Hoje não tem cura. A gente tem remédio, tudo, mas até agora não tem certeza mesmo. Por enquanto vou ter por muito tempo ainda... (Entrev. 8).

\title{
2.6.9 Aceitação e adaptação a doença
}

O processo de aceitação é indispensável, porém depende do apoio, da historia de vida de cada um, entre outros fatores. Segundo Fialho et al (2011), alguns pacientes demonstraram alguma aceitação frente à doença:

"Eu era criança, tinha 11 anos de idade, entendeu? Foi muito difícil [...] mas aí o tempo foi passando, não teve outro jeito, tive que aceitar e aprender a cuidar de mim."

\begin{abstract}
"Hoje eu encaro com mais facilidade. Já me descabelei mais, hoje tá mais fácil de enfrentar, porque o tratamento tá sendo mais fácil. Tá evoluindo, né? Produtos que a gente encontra e não encontrava antes, essas facilidades. Os preços estão mais acessíveis. O chocolate diet, na páscoa tá quase o mesmo preço de um ovo comum. Já tá mais fácil de encarar... É bem mais fácil aceitar agora. "
\end{abstract}

É através da aceitação que o diabético atingirá a etapa do autocuidado e do aprendizado. Moreira e Dupas (2006) ressaltam que devido a essa nova fase a criança passa a aceitar mais e buscando conviver da melhor forma possível com a patologia, conforme pode ser visto pelos relatos dos pacientes pesquisados:

Eu continuei saindo. No Cancun, na Abasc, no shopping. Acho que tudo acaba se acostumando (Entrev. 7).

Ah, eu acho que ficar revoltada não vai ajudar em nada. alvez até atrapalhe mais (...) Então eu comecei a deixar de ficar revoltada, tanto com as pessoas quanto com o diabetes (Entrev.4).

Eu tenho que aceitar e ponto (Entrev. 3).

E a nova adaptação principalmente com a dieta, com o uso da insulina, enfim com o autocuidado é relatado de tal forma, segundo Moreira e Dupas (2006):

Eu tenho um controle certo com a minha alimentação.... Às 10 horas eu como uma fruta, aí eu almoço às 11 e meia... (Entrev.4)

Ah, dizem assim que tem que tomar bastante cuidado com o pé. Eu lavo ele, eu seco entre os dedos, deixo para minha mãe cortar minhas unhas para não inflamar (Entrev. 8). 
Ah, antes eu não aceitava ter diabetes, eu achava que era a pior coisa do mundo. Mas aí eu parei um pouco para pensar e falei: 'Pôxa, tem gente que não tem a perna e queria ter, anda de cadeira de roda e isso é muito pior'. Uma pessoa que sabe que daqui a alguns anos ou daqui a alguns dias ela sabe que não vai estar mais aqui (Entrev. 4).

Aí eu procuro fazer minhas coisas, esqueço até, procuro estudar, me distrair mesmo. (Entrev. 7).

Para Moreira e Dupas (2006) é, neste momento que o paciente começa a adaptar-se a nova realidade, realizando os tratamentos e procurando ajuda médica, conforme explicita o entrevistado 10.

Fiz terapia, eu e minha mãe. Eu parei já. Foi o ano passado, retrasado, toda terça (...). Era ir lá e ficar contando tudo sabe? E demorava, era 1 hora, 1 hora e meia, ficar conversando. Aí no final ela mandava desenhar, ou brincar de jogo, pra ver né, se a criança contava mais depois (Entrev. 10).

O adolescente ao aprender a lidar com sua autonomia este passa para 0 autocuidado sendo capaz de administrar a sua própria insulina, bem como se monitorando e se responsabilizando pela contagem de carboidratos, segundo Fialho et al (2011).

\subsubsection{Compreensão e percepção dos envolvidos}

A compreensão da patologia deve ser encarada na parte biológica, física e além da espiritual, a crença em Deus. Segundo Moreira e Dupas (2006) ao mudar a percepção da doença para a criança/adolescente propiciará aos mesmos uma melhor vivência no seu dia a dia.

Ah, talvez um fato que me deixou muito emocionada, ou porque tinha que acontecer de um modo ou de outro (...). Ele (Deus) poderia até fazer isso para me mostrar alguma coisa (...). Então, se tinha que acontecer comigo, aconteceu e eu só tenho que aceitar e saber controlar (Entrev. 4).

Eu não posso falar: 'eu não quero ter diabetes, eu não vou ter'. Quem manda é Deus, ele sabe o que faz, sabe? Tem que ser assim (Entrev. 10).

Ah, não importa falar, né? Minhas amigas sabem, minha classe inteira sabe, eu acho (Entrev. 8). 
Eles sabem. É assim, a professora deixa eu ir beber água. A professora não deixa os moleques ir beber água, muito, só eu. Eles perguntaram, aí a professora falou que eu tinha diabetes (Entrev. 9).

$\mathrm{Na}$ visão dos autores acima, a percepção da criança deve ir além da doença, isto é, perceber que outras pessoas também têm a mesma doença, e que podem ajudar.

É legal saber que todos se preocupam comigo. Eu também me preocupo com eles quando acontece alguma coisa, sabe? Legal isso... (Entrev. 10).

Quando eu fiquei sabendo minha avó gastou $R \$ 100,00$ com coisa minha. Ela trouxe as coisas pra casa (Entrev. 6).

Fialho et al (2011) complementam que é necessário dar enfoque a outras questões, ressignificando a doença com um novo olhar, uma nova percepção.

Segundo Moreira e Dupas (2006, p.30) ter um olhar diferenciado pela situação é imprescindível para a criança, permitindo assim "... que o diabetes não muda seu jeito de ser e a possibilidade dela ser feliz e viver como as outras pessoas". Os pesquisados relataram que:

Ah, eu acho que não tem muita diferença. Se eu tiver num grupo de cinco adolescentes e me tratarem igual a eles, eu não vou ligar, porque eu me sinto igual a eles (Entrev. 4).

Todo mundo é igual a todo mundo, não trata ninguém diferente (Entrev. 3).

(...) Pelo menos eu gostaria de ser tratada como as outras pessoas. Eu gostaria, pelo menos, de me sentir igual às outras pessoas (Entrev. 4).

Nesse sentido, Fialho et al (2011) ensinam que é necessário a atuação de uma equipe multidisciplinar em prol do diabético abarcando todas as áreas, isto é, fisiológico, o emocional, o social e o cognitivo. Ressaltam também que o atendimento individual permite interagir com a percepção que o mesmo possui sobre si e sua doença.

Além das crianças/adolescentes, a família também sofre com o adoecimento, e para que haja uma convivência harmoniosa, o tratamento deve abarcar toda a família onde os membros apóiam integralmente. 
Uma das formas de poder propiciar crianças e adolescentes diabéticas e familiares são os grupos de iguais, onde os mesmos e os familiares podem vivenciar essa etapa de maneira eficaz.

$\mathrm{Na}$ visão de Delamater apud Marcelino e Carvalho (2008), as terapias psicossociais têm ajudado na melhora do controle glicêmico, bem como na alimentação, na qualidade de vida e no funcionamento psicossocial.

\subsection{Família}

\subsubsection{Diagnóstico}

Os depoentes relatam sobre a percepção dos primeiros sinais da doença: "O que me chamava à atenção nela era a boca seca, porque minha sogra [diabética] reclamava muito que bebia água e parecia que a boca tava plastificada. E eu percebi que a $M$. era assim, ela bebia água e a boca não molhava. " (P 5). (BRITO E SADALA, 2009, p. 954).

“...ele era forte, mais cheinho e emagreceu de uma hora para outra. Bebia muita água, até acordar urinado, ele acordava. E como minha mãe é diabética ela já sabia os sintomas" (Entrev. 7). (CORREIA JR ET ALL, 2014, p. 64-65)

“...ela era gordinha, sabe? Aí a menina comia o tempo todo e começou a emagrecer, aí eu notei através do xixi dela, era muito xixi, e bebia muita água”. (Entrev. 2). (CORREIA JR ET ALL, 2014, p. 64-65)

“...ela estava comendo muito e perdendo peso, tomando muito líquido e fazendo muito xixi. Sempre tomando dois tipos de líquido, várias vezes ao dia, água”. (Entrev. 4). (CORREIA JR ET ALL, 2014, p. 64-65)

“...ela fazia muito xixi, e num instante vinha de novo, e comendo. Comecei a ver emagrecendo aí deu aquele desespero" (Entrev. 1). (CORREIA JR ET ALL, 2014, p. 64-65)

\footnotetext{
...através de uma infecção urinária, ela estava com três anos e não fazia mais xixi na cama e com cinco anos voltou a fazer, ... quando fomos ao médico para ver, era porque ela estava com a infecção urinária muito grave, aí foi diagnosticado que ela era diabética (Entrev. 3). (CORREIA JR ET ALL, 2014, p. 64-65)
}

Com o diagnóstico, o sentimento da família é de desespero. Com a gravidade da patologia condições severas são impostas restringindo as atividades diárias do 
filho. Os temores dos familiares vão desde as crises de hipoglicemia e a hiperglicemia às patologias crônicas conforme relata a mãe do paciente:

Também é muito arriscado, porque se não cuidar direitinho é perigoso! Ela tá com um monte de coisa, né? Esses tempos atrás, morreu um rapaz com 21 anos. Ele teve diabetes com nove anos também. Atacou o coração, porque ataca o coração também, né? $\mathrm{E}$ eu e o Z. , a gente fica preocupado com a D. (P 7) (BRITO E SADALA, 2009, p. 954).

2.7.2 Após o diagnóstico

A negação da patologia é a primeira reação manifestada pelos familiares frente ao diagnóstico do filho. "A primeira coisa que a gente sente é a negação: 'então, trocaram o exame dele, não é ele, amanhã não tem nada a ver, vai dar tudo diferente. E durante a noite foi a mesma coisa. Você sonha que não aconteceu com você. " (P 3). (BRITO E SADALA, 2009, p. 954).

Quanto as mudanças de comportamento dos pacientes as mães relataram:

“...mudou. Assim, porque tem dia que ela está muito agressiva, quando está alta (a glicemia). Ela fica muito parada, quieta”. (Entrev. 3).

“...observei-o agitado, querendo levar a vida dos outros meninos. Ele tem muito medo, medo de tudo, ficou mais frágil, depois da doença”. (Entrev. 7).

“...notei-a mais nervosa, estressada, principalmente quando a glicemia está alta. Fica inquieta, chora, briga, grita, fica totalmente descontrolada”. (Entrev. 4).

“...observei-a mais nervosa, agressiva. A principal mudança foi o nervosismo”. (Entrev. 1). (CORREIA JR ET ALL, 2014, p. 63)

Apesar de algumas mudanças comportamentais serem percebidas no momento do diagnostico, segundo a mãe de um paciente não houve modificações tais como observa-se no relato "...Bom a mudança que ele teve foi somente que antes ele era mais forte..., mas mudança no jeito dele ser, não”. (Entrev. 6).

\subsubsection{Reação ao tratamento}

No tocante ao tratamento, a percepção dos pais vai alem da medicação, da alimentação, isto é, que precisam ajudar o filho no processo de aceitação da doença. 
Tem muitas coisas às vezes que ele duvida. Então você tem que tá um pouquinho mais estudada pra poder questionar, então você tem que tá um pouquinho preparada pra resposta, porque se não ele fala: 'Então se não tem problema eu vou fazer'. (P 3). (BRITO E SADALA, 2009, p. 954).

Uma outra questão relacionada ao tratamento é a insulina, ao qual é citada como um tratamento agressivo e doloroso. "Até hoje ele não aceitou muito bem a insulina”. (BRITO E SADALA, 2009, p. 954).

Mudanças acerca do uso dos medicamentos as mães relataram:

"...a única coisa que eu tiraria eram essas injeções, porque fica sofrido tanto para a gente quanto para ela. Então eu colocaria remédios para beber, para tomar". (Entrev. 2). (CORREIA JR ET ALL, 2014, p. 64)

“...tiraria a insulina, achar um tratamento que não precisasse ser puncionada todo dia de manhã e de noite, por causa da dor. A pessoa se fura demais (puncionada)". (Entrev. 1). (CORREIA JR ET ALL, 2014, p. 64)

"...A única coisa que eu mudaria, para ele não ser furada (puncionada) tantas vezes ao dia. Quando diz: Hora da insulina. Ele fala: ai meus dedinhos! (glicemia)". (Entrev. 7) (CORREIA JR ET ALL, 2014, p. 64)

Com relação a alimentação a paciente relata: "Então sempre é uma luta". ( $P$ 1) (BRITO E SADALA, 2009, p. 954).

\subsubsection{Mudanças na família}

A Diabetes Mellitus tipo 1 instaura no seio familiar mudanças que envolve todos os familiares e a necessidade de adaptar-se à nova realidade. "Muda completamente a rotina da casa, de todo mundo. " (P 8). (BRITO E SADALA, 2009, p. 954).

"Foi muito difícil e na adolescência dela foi pior ainda, porque ela não aceitava a doença, a alimentação. Não aceitava tomar a insulina, quer dizer. Ela vinha parar aqui, ruim. Ficava internada na CTI, ficava muito ruim mesmo. " (P 6). (BRITO E SADALA, 2009, p. 954). 
Mudanças ocorrem também na alimentação e na vida financeira da família que a patologia exige:

“...a gente tem aquela preocupação de não entrar doce, a gente tenta fazer a mesma alimentação que ele. Tenta colocar ele para fazer exercício, a gente tenta levar a mesma rotina dele”. (Entrev. 7). (CORREIA JR ET ALL, 2014, p. 66)

“...a gente começou a comer tudo igual a ela, mais verdura, coisas mais diet. Eu gostava muito de macarronada, essas coisas doces e eu não faço mais. Ficou todo mundo comendo igual a ela”. (Entrev. 4). (CORREIA JR ET ALL, 2014, p. 66)

“...Interfere assim, porque às vezes a gente quer comer alguma coisa que a gente tem vontade e já se preocupa de ter aquilo ali por causa dela”. (Entrev. 1). (CORREIA JR ET ALL, 2014, p. 66)

“...aqui em casa não se faz um bolo, não entra doce, muita coisa a gente deixa de fazer. Faz a feira, já não coloca certas coisas". (Entrev. 3). (CORREIA JR ET ALL, 2014, p. 66)

\subsubsection{Sentimentos quanto ao DM1}

A Diabetes Mellitus Tipo 1 gera nos pais sentimentos de inconformidade: "Graças a Deus ele está bem, mas é duro saber que é uma coisa que vai ter que conviver pro resto da vida. " (P 2) (BRITO E SADALA, 2009, p. 956).

Sentimentos de vergonha, de inferioridade fazem com que crianças/adolescentes escondem sintomas de hiper ou hipoglicemia. "Ele tem vergonha de dizer perto dos outros que não tá bem" (P 2), (BRITO E SADALA, 2009, p. 955).

Correia $\mathrm{Jr}$ et all, relatam os sentimentos dos cuidadores quanto ao Diagnóstico:

“...ficou todo mundo desesperado. Eu estava desesperada” (Entrev. 1). (CORREIA JR ET ALL, 2014, p. 65)

“...uma tristeza imensa, você sabe, não é? Uma coisa dessas envolve a família todinha. Na verdade, o mundo desaba, é incrível mexe muito com a gente, você saber que é uma doença para a vida inteira". (Entrev. 3). (CORREIA JR ET ALL, 2014, p. 65) 
“...muito desgosto, não é? Muita tristeza em saber que a diabetes é uma doença que não tem cura". (Entrev. 4). (CORREIA JR ET ALL, 2014, p. 65)

"...na hora que vi o exame, foi uma angústia tão grande, uma agonia, quase morri. Porque ele bem pequenininho". (Entrev. 6) (CORREIA JR ET ALL, 2014, p. 65)

2.7.6 Dificuldades financeiras

No tratamento da Diabetes Mellitus Tipo1, há um aumento no gasto financeiro da família, o que pode dificultar nas exigências da: "Foi muito duro, porque meu marido ganhava muito pouco, né, e eu também ganhava muito pouco. " ( $P$ 2) (BRITO E SADALA, 2009, p. 954).

No tocante à reeducação alimentar os familiares relataram:

“...aumentou os gastos. Porque as coisas do diabético são caras, ele gosta de um achocolatado e o preço é muito alto para quem tem esses problemas". (Entrev. 6). (CORREIA JR ET ALL, 2014, p. 66)

"...aumenta muito os gastos. Agora as fita e a insulina eu recebo do posto, mas aumentou também por causa da alimentação, por ser muito cara essas coisas diet". (Entrev. 2). (CORREIA JR ET ALL, 2014, p. 66)

"...gasta demais. A gente teve que fazer um empréstimo para poder resolver". (Entrev. 5). (CORREIA JR ET ALL, 2014, p. 66)

"...interfere nas despesas, porque a alimentação de um diabético tem que ser assim, mais com frutas, verduras, legumes e isso é caro e o poder aquisitivo infelizmente é baixo". (Entrev. 1). (CORREIA JR ET ALL, 2014, p. 66)

\subsubsection{Atendimento dos profissionais}

Essa patologia exige um acompanhamento profissional qualificado tanto para a família quanto para o paciente. As mães relataram:

. "...o acompanhamento é ótimo. Ele adora a médica. Recebemos a fita, recebemos a insulina, as agulhas". (Entrev. 7). (CORREIA JR ET ALL, 2014, p. 66) 
“...sim, a doutora dela. É muito bom o atendimento, ela é uma médica muito boa. Hoje eu recebo tudo do SUS, a fita, a insulina, lá no posto". (Entrev. 4). (CORREIA JR ET ALL, 2014, p. 66)

"...o acompanhamento dele é bom, a doutora é pelo posto de saúde e é muito bom. A gente recebe tudo de lá, todos os meses do ano". (Entrev. 6). (CORREIA JR ET ALL, 2014, p. 66)

"...é ótimo, lá do posto. Desde o início, foi lá o acompanhamento. Recebi um aparelho e recebo todos os meses as tiras teste e a insulina". (Entrev. 1). (CORREIA JR ET ALL, 2014, p. 66)

Há também a incompreensão por parte dos profissionais, como é relatado pela entrevistada: "Chega num lugar [para ser atendido] a gente fala que ele é diabético e eles não tão nem aí. " (P 4). (BRITO E SADALA, 2009, p. 954).

Correia et al (2014) mostram que um dos pacientes acessam a unidade de saúde apenas para receber a medicação em razão de ter cobertura de plano de saúde.

...ela tem psicóloga, é acompanhada pela nutricionista, tem a médica. $A$ gente paga o plano de saúde e temos esse acompanhamento. Mas aqui está precisando de um posto, igual ao de Barbalha-CE. Que acompanha como um todo, lá tem psicóloga para a família, nutricionista, tem tudo, e aqui está precisando (Entrev. 3).

Contudo, a intervenção da equipe de saúde é importante no processo de acompanhamento ao paciente e sua família, com perspectiva de harmonizar o tratamento e proporcionar uma melhor qualidade de vida ao assistido.

\subsubsection{Escola}

A criança sente envergonhada e constrangida frente aos colegas da escola, segundo a mãe:

Ele se sente muito rejeitado, na escola. Depois que descobriu, ele não foi mais o que era na escola. Começou a se desinteressar [choro], tirar nota ruim, chorar, sabe? Ele usa a doença e a gente vê que realmente tem hora que é isso, mas a gente é mãe, né? Eu tenho fé que no final dá tudo certo. Ele só falta da escola, não faz a lição porque ele perdeu o interesse por tudo, não quer brincar, não quer sair. Então ele fica muito apegado a mim. (P 4) (BRITO E SADALA, 2009, p. 955) 


\title{
2.7.9 Relação com os pais.
}

Devido à patologia, os pais sentem-se obrigados a deixar sua própria vida de lado supervalorizando a do filho, interferindo na autonomia de ambos e criando uma relação de extrema dependência. "É aquela preocupação, e a mãe fica preocupada. Toda vez que sai, viaja, a gente pede pra avisar onde tá, horário que saiu, horário que chegou. " (P 1). (BRITO E SADALA, 2009, p. 955)

Os pais tentam superar a sua angustia aproximando-se do filho no intuito de ajudá-lo na conscientização da doença e facilitando o seu viver.

\begin{abstract}
Aí vem aquela segunda fase, que você sabe que vai ter que ser forte de qualquer jeito, que seu filho vai precisar da sua força. Então eu não tinha chance de me abater. Eu tinha que passar pra ele que ele tinha um problema de saúde, mas que ele tinha a vida inteira pela frente. ( $P 3)$. (BRITO E SADALA, 2009, p. 955).
\end{abstract}

2.7.10 Conflito entre irmãos

Devido às mudanças que a patologia designa, no tocante aos hábitos alimentares, as atenções que ficam divididas, as relações familiares muitas das vezes se tornam conflituosa conforme explicita a paciente: "Acarreta problemas em geral, porque eu tenho um filho mais velho e um mais novo. Ele é o do meio. Então acontece a cobrança dos outros filhos. " (P 10). (BRITO E SADALA, 2009, p. 955)

“...ela é gêmea com ele. E o cuidado ficou voltado para ela, tivemos problema com ele. Pois, começou a se sentindo rejeitado. Foi obrigado eu rever o que estava fazendo". (Entrev. 3). (CORREIA JR ET ALL, 2014, p. 66)

\subsubsection{Tratamento sociabilidade}

No delinear do processo da doença, os pais percebem que o tratamento deve ser dado igualmente a todos independente da doença. "Lá em casa a gente tenta tratá-lo da maneira mais natural possível. Ele leva bronca, castigo, tudo normal porque eu percebi que assim ele se sente melhor, do que a gente ficar protegendo, cercando de mimos. " (P 3). (BRITO E SADALA, 2009, p. 955)

O apoio dos colegas é um aliado fundamental nesse processo: "As amiguinhas, se ela vai a festas, ajudam ela a não comer o que não pode. Todo 
mundo colabora um pouco pra ficar fácil pra ela. ” (P5) (BRITO E SADALA, 2009, p. 955)

No tocante ao lazer, as relações sociais, as entrevistadas relatam:

“...a gente passeia, mas tenta não ir para lanchonete, porque ele não pode”. (Entrev. 6). (CORREIA JR ET ALL, 2014, p. 66-67)

“...você vai para um clube, para um aniversário de um coleguinha você é obrigado a levar sempre um refrigerante de lado, porque nem sempre tem o que ela pode. Tem que levar o lanche e tem que levar a insulina. Interfere em tudo mesmo". (Entrev. 3). (CORREIA JR ET ALL, 2014, p. 66-67)

\subsubsection{Apoio familiar}

Vários são os sentimentos expressados pelos pais no tocante ao estarem desempenhando o seu papel e alia a atuação do filho no processo de sua doença. "Eu faço a minha parte, eu sou responsável por $50 \%$, os outros é dele! " (P 10) (BRITO E SADALA, 2009, p. 955)

Diante da situação mudanças nos relacionamentos familiares ocorreram e os pais expuseram que com isso houve uma união entre todos.

“... Todos se envolveram. Todo mundo se uniu, todo mundo dá carinho, foi mais unido ainda, todo mundo participa, os irmãos, os primos, todo mundo". (Entrev. 2). (CORREIA JR ET ALL, 2014, p. 65)

“...a única mudança foi que uniu mais a gente. A gente era unido, mas aí uniu ainda mais para cuidar dela”. (Entrev. 4). (CORREIA JR ET ALL, 2014, p. 65)

“...assim, os irmãos falaram: "mamãe vamos ter cuidado". Não teve nenhuma coisa negativa não. Fizeram foi ajudar, graças a Deus todos são unidos sobre isso". (Entrev. 7). (CORREIA JR ET ALL, 2014, p. 65)

“...Todos ficaram preocupados de ver ela desse jeito. Ficamos mais unidos por causa dela, com cuidado com ela" (Entrev. 5). (CORREIA JR ET ALL, 2014, p. 65). 


\subsubsection{Participação das mães}

As mães demonstram o sentimento de impotência frente a patologia do filho. "Por mais que você faça, tá sempre faltando alguma coisa. " (P 10). (BRITO E SADALA, 2009, p. 955)

Uma das mães relata que se sente como polivalente (mãe, enfermeira, amiga) e de ser responsável pelo cuidado do mesmo. "A gente tem que ser tudo. " (P 8). (BRITO E SADALA, 2009, p. 955). Os autores relatam que o cuidado do filho é praticamente da mãe.

\subsubsection{Motivação}

A aceitação da doença é imprescindível para ajudar o filho e estimulá-lo para novas possibilidades: "Eu falei pra ele que a diabetes tirou algumas coisas da vida dele, mas que não pode tirar o resto, e ele não pode deixar. Então é mais ou menos assim que a gente trabalha com o G." (P 3). (BRITO E SADALA, 2009, p. 955).

A gente vai levando. ( $P$ 1).... O tratamento, a gente vê que logo haverá uma possibilidade de cura, mas acho que tem muito comércio dos laboratórios nisso, e não saiu nada ainda. Mas a esperança é que um dia saia, porque eles são jovens ainda e têm uma vida inteira pela frente. E a gente tá torcendo por isso! (P 1). (BRITO E SADALA, 2009, p. 956).

"...a gente fica triste. Fica pensando porque que aconteceu isso com ele, uma criança ainda. Aos seis anos, mas hoje já somos mais conformados". (Entrev. 7). (CORREIA JR ET AL, 2014, p.65)

"...queria morrer. Desesperei-me, mas, depois que eu vi assim, que era uma coisa normal, que é uma doença que tem suas consequências, mas que também pode ser levada uma vida normal". (Entrev. 5). (CORREIA JR ET AL, 2014, p.65)

O Encorajamento de continuar e não desistir é expresso por uma paciente: "Ele não pode deixar de viver por causa disso". (P 3) (BRITO E SADALA, 2009, p. 956) 
2.7.15 Não controle da patologia

A Diabetes Mellitus Tipo 1 tem suas complicações derivadas do não controle da patologia.

O DR S. segurou ele um pouco lá a cada três meses. [A glicemia] tá sempre alta, em jejum 500 e pouco, é sempre assim. Então ele chegou num ponto que ou ele vai cegar. Já tá tomando remédio pro rim, mas também não tomou mais. Tudo é assim, tudo que é pra ele fazer ele não faz. (P 10) (BRITO E SADALA, 2009, p. 955 - 956)

\subsubsection{Fé religiosa}

Alguns pais se confortam na fé religiosa: "Cura ainda não tem, só Deus pra curar. E enquanto isso não acontece, tem que seguir em frente porque a vida continua. É que eu falo pra ele, que a vida continua”. (P 4) (BRITO E SADALA, 2009, p. 956)

A esperança de cura é o que pais citaram que buscariam para mudar a historia de seu filho.

“...Mudar? Eu queria uma cura, a cura” (Entrev. 5). (CORREIA JR ET AL, 2014, p. 64).

“...Não sei assim, se eu pudesse mesmo, se estivesse ao meu alcance eu faria qualquer coisa que curasse. Buscar a cura”. (Entrev. 4). (CORREIA JR ET AL, 2014, p. 64).

\subsubsection{Complicações do DM1}

Os relatos denotam a preocupação com o futuro, isto é, as complicações que a patologia pode desencadear.

“...não piorou, mas hoje a gente vive, em uma atenção maior. Principalmente, por ela já ter sido internada na UTI. Você vive sempre tensa". (Entrev. 3). (CORREIA JR ET AL, 2014, p. 67).

A vida vai se normalizando apesar das vivencias conturbadas, segundo as pacientes: 
"...uma vida normal. Tem esse obstáculo, mas graças a Deus, a gente consegue superar, hoje em dia está tudo normal". (Entrev. 5). (CORREIA JR ET AL, 2014, p. 67).

"...está normal, porque eu aprendi e essas coisas todas dela eu acostumei". (Entrev. 4). (CORREIA JR ET AL, 2014, p. 67).

“... Normal. É ótima, graças a Deus, mesmo com esse obstáculo que a gente tem, mas a gente vai superando". (Entrev. 2). (CORREIA JR ET AL, 2014, p. 67).

“...Está a mesma coisa. A vida ficou normal". (Entrev. 1). (CORREIA JR ET AL, 2014, p. 67).

\subsubsection{Autocuidado}

Segundo as entrevistadas, o processo educativo foi bem aceito pelo seu filho propiciando o autocuidado.

“...é ele mesmo. Às vezes, eu estando em casa eu mesmo aplico a insulina nos braços, mas ele mesmo tira a glicemia, toma a insulina no horário. Ele sabe que tem o problema, nunca me deu trabalho, sabe o que pode comer e o que não pode". (Entrev. 6). (CORREIA JR ET AL, 2014, p. 63).

"...É sim. Ele aprendeu direitinho, já diz "não mãe pode deixar que eu sei." Foi treinar lá no posto de saúde. Quando ele está perdendo peso ele já sabe, ele aprendeu e faz bem direitinho". (Entrev. 7). (CORREIA JR ET AL, 2014, p. 63).

"...Ela é educada, aplica na tia dela, tira a glicose (glicemia) dela e da tia. Aceita normal". (Entrev. 5). (CORREIA JR ET AL, 2014, p. 63).

As reações do processo educativo e consequentemente do autocuidado tiveram reações negativas segundo duas participantes:

"...Eu tenho um irmão médico que me ajuda muito nesse sentido, ele pesquisa muito e sempre me diz e fala sobre a alimentação. Mas ela não reage bem, não aceita e não pratica a educação do tratamento dela". (Entrev. 3). (CORREIA JR ET AL, 2014, p. 63).

“...Ela não faz. Come demais, não faz os exames como é para fazer. Ela foi educada, fazer o autocontrole, o exame, tomar o medicamento, a insulina. Ela pula, não toma. Seria o ideal que ela tomasse e fizesse os exames". (Entrev. 4) (CORREIA JR ET AL, 2014, p. 63). 


\subsection{Autocuidado}

A Diabetes Mellitus Tipo 1 provoca alterações no organismo do paciente e para tal há a necessidade da atuação de diversos profissionais. (DAMO ET AL, 2013).

É através da determinação, da intenção e da vontade de um propósito para que algo ocorra é que existe o cuidado. E por vontade esta pode ser subjetiva ou objetiva. A vontade subjetiva deve ser mediada "...por valores, motivações para a vida e consciência das implicações de uma não adesão às ações de cuidado e saúde" e esta também pode ser derivada de "... uma condição objetiva situação limite de continuação da própria vida". E para chegar a autonomia é necessário que as condições objetivas e subjetivas estejam presentes. (SIMÃO ET AL, 2013, p.3).

Para que a autonomia esteja presente é relevante que o paciente tenha real compreensão do seu estado de saúde, pois a falta de informação sobre sua doença o limita na busca de sua autonomia.

As atuações dos profissionais de saúde devem basear-se no diálogo, na troca de saberes, de experiências, isto é, de forma a possibilitar a "... a integralidade do cuidado ao paciente e a formação de profissionais". (PEDUZZI apud DAMO ET AL, 2013, p.180).

A visão do paciente como um sujeito ativo e não como submisso aos saberes técnicos do profissional de saúde inibindo-o às ações para o autocuidado propicia ao paciente a adesão ao cuidado. Segundo Mendes apud Simão et al (2013, p.4) "o autocuidado apoiado sustenta-se no princípio de que as pessoas conhecem tanto quanto, ou mais, que os profissionais de saúde acerca de sua condição de saúde e de suas necessidades de atenção".

A importância do profissional no autocuidado é essencial, pois transmite aos pacientes conhecimentos, técnicas que possibilitem a autonomia e o autocuidado, ações estas indispensáveis para o controle da doença. (DAMO ET AL, 2013). 
Quadro 3 - Fatores que facilitam e dificultam o manejo do diabetes, na perspectiva da criança - Ribeirão Preto - 2009

\begin{tabular}{|c|c|c|c|}
\hline \multicolumn{4}{|c|}{ Fatores que interferem no manejo do DM Tipo 1, na perspectiva da criança } \\
\hline Categorias & & Facilitam & Dificultam \\
\hline Viver com diabetes & & $\begin{array}{l}\text { Valorizar a experiência da } \\
\text { criança; conhecer, enfrentar e } \\
\text { aceitar a doença; crenças e } \\
\text { sentimentos positivos. }\end{array}$ & $\begin{array}{l}\text { Desconhecer a doença, } \\
\text { enfrentar como uma luta diária, } \\
\text { preconceitos, isolamento. }\end{array}$ \\
\hline $\begin{array}{l}\text { Autocuidado e perfil } \\
\text { glicêmico. }\end{array}$ & & $\begin{array}{l}\text { Valores glicêmicos dentro da } \\
\text { normalidade; auxilio para } \\
\text { autoaplicação e decisão para } \\
\text { escolha dos alimentos. }\end{array}$ & $\begin{array}{l}\text { Privação de alimentos, } \\
\text { interrupção de atividades para } \\
\text { lidar com demanda da doença; } \\
\text { medo e deficiência na técnica } \\
\text { de autoaplicação; recursos } \\
\text { insuficientes. }\end{array}$ \\
\hline $\begin{array}{l}\text { Família, amigos } \\
\text { profissionais da saúde. }\end{array}$ & e & $\begin{array}{l}\text { Apoio familiar, de amigos e } \\
\text { profissionais, envolvimento } \\
\text { familiar, vinculo e valorização } \\
\text { da criança; } r \text { equipe } \\
\text { multiprofissional. }\end{array}$ & $\begin{array}{l}\text { Falta de apoio dos pais; } \\
\text { conflitos familiares e ambientes } \\
\text { estressantes; dificuldade de } \\
\text { relacionamento com amigos. }\end{array}$ \\
\hline Papel da escola & & $\begin{array}{l}\text { Apoio dos amigos; local } \\
\text { adequado para armazenar } \\
\text { materiais; informações aos } \\
\text { amigos e professores; visitas } \\
\text { escolares por profissionais de } \\
\text { saúde; atividades educativas. }\end{array}$ & $\begin{array}{l}\text { Local inadequado para o } \\
\text { autocuidado; interrupção de } \\
\text { atividades escolares; cantinas } \\
\text { inadequadas; falta de } \\
\text { conhecimento; indiferença da } \\
\text { equipe escolar; inflexibilidade de } \\
\text { regras escolares; medo de ser } \\
\text { julgado pelos amigos; bullying. }\end{array}$ \\
\hline
\end{tabular}

Fonte: Nascimento et al (2010, p. 766)

A proposição saúde-doença implica em um trabalho com diferentes profissionais envolvidos cada qual com seu saber técnico, mas que unidos produzirão um resultado em prol da saúde. Sendo a saúde “... imprescindível para o exercício da autonomia na busca de manutenção da própria vida" (SIMÃO ET AL, 2013, p.4). 
Nessa interação de diversos profissionais e na busca do cuidado tais especificidades devem possuir conhecimentos e habilidades para:

\begin{abstract}
a) perceber a perspectiva do usuário do serviço, tratando-o como sujeito participante das decisões do cuidado e considerando suas preferências; b) orientar para a busca de informações seguras com apoio à autopromoção, potencializando o autocuidado; c) notificar sobre as probabilidades de riscos da atenção; c) utilizar tecnologias que facilitem o engajamento das pessoas no seu cuidado; d) delimitar e gerenciar metas para a construção do autocuidado. (MENDES apud SIMÃ̃O ET AL 2013, P.3)
\end{abstract}

Nesse sentido, a integração de saberes, conhecimentos, técnicas de profissionais de áreas diferentes tem contribuído para o acompanhamento do paciente em sua integralidade (DAMO ET AL, 2013).

No "Programa de Educação em Saúde", na Universidade Regional de Blumenau, com vários projetos para atendimentos de crianças e adolescentes portadores de Diabetes, sendo que um deles é o "Doce Sorriso - Assistência e Promoção de Saúde Bucal". (DAMO ET AL, 2013).

No caso da odontologia, os níveis glicêmicos também devem estar normalizados para que ocorra o tratamento necessário.

Diante dos relatos de pacientes atendidos, as maiores dificuldades são: 0 desjejum, o horário da primeira dose matinal de insulina e a dieta adequada, sendo que o não cuidado interfere no controle glicêmico, e o tratamento odontológico devera então ser limitado.

Durante um procedimento odontológico de restauração dental, houve um
evento de hipoglicemia em um dos adolescentes atendidos. No início do
atendimento, o valor de glicemia capilar era de $164 \mathrm{mg} / \mathrm{dl}$. Durante o
atendimento, o adolescente manifestou estar se sentido mal e nova medida
da glicemia capilar foi realizada, correspondendo a $52 \mathrm{mg} / \mathrm{dL}$. Na ocasião, foi
eleito como responsável pelo evento ocorrido cimento de ionômero de vidro,
usado como material restaurador. Por se tratar de uma lesão de cárie
profunda, com possibilidade de exposição pulpar sem sintomatologia
dolorosa, optou-se pelo capeamento indireto. Esse episódio foi uma
experiência ímpar para os profissionais e discentes envolvidos, já que
eventos dessa natureza não são cotidianamente vistos no atendimento
odontológico. (DAMO ET AL, 2013, p. 184)

A participação do paciente diabético propicia melhora na glicemia capilar o que denota o autocuidado podendo assim ser submetido ao tratamento odontológico. "A motivação ao cuidado da saúde bucal foi, então, realizada por meio da orientação acerca do correto cuidado com os dentes e do alerta sobre as consequências do não tratamento". (DAMO ET AL, 2013, p.184). 
Delors apud Damo et al (2013, p. 184) ensinam que:

\begin{abstract}
A experiência proporcionada gerou aprendizado, construção do conhecimento e crescimento profissional e humanístico aos docentes, coordenadora e pesquisadores envolvidos nos projetos. Apesar de haver uma definição bastante clara do papel a ser exercido por cada profissional, devido à própria especificidade da área de cada um, houve diversos momentos em que as funções foram comuns, de maneira absolutamente natural. Nesse sentido, percebem-se os quatro pilares da educação - agir, saber, ser e fazer - entre profissionais da saúde podem estar fortemente ligados.
\end{abstract}

A integração do profissional, pacientes e familiares promove uma maior conscientização sobre a saúde através de estratégias educativas que propiciarão maior segurança e motivação para o autocuidado. (DAMO ET AL, 2013)

Simão et al (2013) verificaram que a necessidade de avanço no apoio ao cuidado, a equipe desenvolveu uma pesquisa das ações desenvolvidas pelo Programa de Extensão de Educação em Saúde da Universidade Regional de Blumenau. O projeto é voltado ao cuidado da criança e do adolescente com Diabete Mellitus Tipo1 atendidos no Ambulatório Universitário o que integra a rede de serviços do SUS. A equipe trabalha de modo intermultiprofissional e o público alvo são adolescentes com Diabete Mellitus Tipo 1 e o cuidadores responsáveis usuários da rede do serviço de Sistema Único de Saúde. A pesquisa foi efetuada nos meses de abril à junho de 2012, tendo este como objetivo: “... iluminar novas ações intermultiprofissional para a promoção da adesão como expressão do autocuidado e do cuidado apoiado pelos profissionais e familiares". (SIMÃO ET AL, 2013, p. 3).

No tocante à adesão ao tratamento e a autonomia no cuidado, os profissionais de tal instituição ainda não estão contribuindo efetivamente para o autocuidado, o que "... possivelmente vem contribuindo no processo de não adesão ao tratamento pelos adolescentes". (SIMÃO ET AL, 2013, p.3).

Aos cuidadores, estes relatam duvidas quanto ao cuidado para o paciente diabético, devido a comunicação entre eles e os profissionais não ser entendível.

Quanto ao horário da aplicação da insulina a cuidadora relatou "Meu filho acorda tarde e aí não consigo fazer no horário marcado pela Doutora e por isso deixo aplicar a insulina". Já o profissional relatou que: "Faço a prescrição considerando um padrão, porém, se tivessem comentado a dificuldade de aplicação no horário prescrito, tê-lo-ia adequado à rotina do adolescente e assim ele não ficaria sem o medicamento". (SIMÃO ET AL, 2013, p.4). 
Com relação na organização do cardápio nutricional há pouca adesão, que podem estar relacionados à vergonha por dificuldade financeira, pela falta de estímulos para se posicionarem frente ao profissional ou pelo distanciamento da comunicação entre profissionais e da pessoa cuidada.

Os conflitos familiares derivados pela alimentação diferenciada é uma variável dos portadores da DM tipo 1. As dificuldades relatadas são: o preço alto dos produtos o que impossibilita a aquisição dos mesmos. Tal fato pode levar ao adoecimento devido a não adesão ao tratamento.

As reuniões da equipe interdisciplinar busca minimizar tais impactos, adequando o cardápio as condições econômicas da família. A adequação de alimentos mais baratos na alimentação do paciente diabético é uma dificuldade encontrada pela família por desconhecimento, como bem nos coloca Simão et al (2013, p.6) “ ... então, no mínimo, está ocorrendo descompasso na comunicação entre os profissionais e os cuidadores, manifestando fragilidade no empoderamento para o autocuidado".

No tocante à quantidade, os adolescentes relataram que esta " era pequena" e que "gostam muito de pão e a quantidade estipulada não os satisfaz". (SIMÃO ET AL, 2013, p. 6).

A profissional de nutrição recomendou-os associar pão com legumes aumentando a quantidade de fibras e consequentemente aumento no exercício físico.

Os pais relataram a preocupação com a quantidade da alimentação e da hiperglicemia, sendo este resultante do uso inadequado da insulina, segundo o endocrinologista, o que para os cuidadores e adolescentes não foi bem internalizado.

Quanto ao aparato odontológico, a não adesão é devido a dificuldade quanto ao horário disponibilizado para os pacientes.

Com relação ao apoio social, as entrevistadas enfatizaram a escola como um limitador ao cuidado do diabético, por serem alvos de bullying e excluídos por causa da merenda escolar. Expressões tais como "Pensei que você tivesse morrido" de professores após a ausência do adolescente, foram relatados gerando no estudante a falta de motivação para freqüentar a escola.

Uma outra variável identificadora foi o monitoramento do autocuidado como expressão do cuidado apoiado. Para a efetividade da variável é necessário um 
investimento na educação bem como uma intervenção de apoio propiciando maior confiança dos usuários. Mendes apud Simões et al (2013, p.13) relatam que é imprescindível "[...] habilidades dos sistemas de atenção à saúde em gerenciar seus problemas, o que inclui o monitoramento regular das condições de saúde, o estabelecimento de metas a serem alcançadas e o suporte para a solução desses problemas".

A autonomia do cuidado tem como ferramenta o apoio e este deve ser capaz de propiciar conhecimentos e habilidades nos pacientes com intuito de manter controle sobre a doença, mudança de comportamentos para a melhora na qualidade de vida entre outros.

Simão et al (2013) ainda ressaltam que outro limitador da autonomia é a ausência do Estado no tocante ao cuidado da saúde, isto é, em deixar de cuidar das necessidades básicas do cidadão.

Mendes apud Simão et al (2013, p.13) ensinam que os pilares para a construção do autocuidado são: “... a informação e a educação para o autocuidado, a elaboração e o monitoramento de um plano de autocuidado e o apoio material para o autocuidado"..

Neste sentido o autocuidado exige um monitoramento regular e sistematizado e para tal devem estar presentes os objetivos a serem alcançados a longo prazo, identificando as barreiras e as estratégias para a superação das mesmas, bem como verificar o cumprimento das metas e o grau de confiança dos pacientes no atingimento das metas e estas devem ser definidas e delimitadas através de um plano de ação descrevendo o que fazer para o alcance das mesmas.

\subsection{Projeto do Hospital das Clínicas}

O ambulatório da Criança e Adolescente Diabéticos do Hospital das Clínicas da UFMG, que "atende à região metropolitana de Belo Horizonte e é centro de referência para todo o estado de Minas Gerais" (Silva et al, 2004, p. 2), com a experiência na área, verificaram a necessidade de ampliação e aprimoramento do trabalho, bem como propôs novas metas.

A equipe multiprofissional é composta por profissionais do Serviço Médico da Enfermagem, da Psicologia, da Nutrição, do Serviço Social e os residentes da 
Pediatria e da Endocrinologia do Hospital em questão e alunos de graduação em medicina.

Os objetivos deste projeto

[...] são promover o crescimento e desenvolvimento satisfatórios e prevenir o aparecimento de complicações, preservando a qualidade de vida. Hoje está bem estabelecido que a prevenção das complicações agudas e crônicas só é possível com a manutenção da glicemia normal ou próxima do normal. (SILVA ET AL, 2004, p.5)

Isto devido ao fato de a Diabetes Mellitus tipo 1, se apresentar um problema crescente de saúde no mundo.

No tocante à DM1, o objetivo do tratamento é de:

Nossa proposta é melhorar o atendimento de uma parcela de diabéticos tipo $1 \mathrm{com}$ a reorganização do setor, perseguindo a meta de fornecimento gratuito de medicamentos e material para auto-monitorização para a população carente e vislumbrando a possibilidade de ampliação dessa cobertura em futuro próximo (SILVA ET AL, 2004, p.3)

O atendimento tem previsão de ocorrer nos consultórios do Hospital Bias Fortes, anexo do HC-UFMG e terá como apoio o Departamento de Pediatria da Universidade Federal de MG, o Hospital das Clínicas, o Hospital São Geraldo (UFMG), bem como o Laboratório Central do HC.

No que se refere à metodologia, Silva et al (2004, p.13) ressaltam que a implementação do Projeto contemplará várias etapas, tais como: "[...] melhoria do entrosamento e homogeneização das condutas da equipe, bem como adequação dos atendimentos". Introdução de novas técnicas de abordagem e concomitantemente, ações com perspectiva de amenizar algumas carências que se apresentam atualmente e atrapalham o tratamento.

Objetivando ampliar o conhecimento e adesão do paciente e seus familiares em relação à importância da assistência global, foi pensando um calendário que possibilitará a organização e ampliação dessas atividades, que já são praticadas. $O$ calendário contempla:

a) Reuniões periódicas com objetivo de aprimoramento científico e estudo de casos;

b) Atendimento dos pacientes no ambulatório, com agendamento prévio (consultas médicas, com enfermagem, de psicoterapia e nutrição) 
c) Grupos para discussão do tema diabetes, que compõe o "Grupo Educativo em Diabetes";

d) Atendimentos ambulatoriais de urgência em casos que são detectados níveis elevados da glicemia, com perspectiva de evitar a internação do paciente.

Pelo Projeto apresentado, o trabalho multiprofissional será divido em cinco equipes: a equipe médica - endocrinologia pediátrica, equipe de enfermagem, equipe de nutrição, equipe de psicologia e a equipe de assistência social. O referido projeto terá seu desenvolvimento da seguinte forma:

A equipe médica - endocrinologia pediátrica "deverá prestar toda informação ao paciente e à família, sobre como administrar a insulina e ajustar a dose, realizar as glicemias capilares, reconhecer e tratar a hipoglicemia. " (SILVA ET AL, 2004, p.17)

Três etapas compõem o tratamento: a insulinoterapia, a dieta e o exercício físico.

A insulinoterapia é preparada para cada paciente especificamente, de forma que:

[...] os esquemas terapêuticos devem ser individualizados, visando a restauração do metabolismo intermediário. Os horários de administração da insulina e da alimentação devem ser adequados à faixa etária e às atividades diárias do paciente. [...] (SILVA ET AL, 2004, p. 17)

Existe uma variação do resultado da glicemia, conforme o horário da aplicação do exame e a alimentação. O paciente pode apresentar hipoglicemia ou hiperglicemia. Por este motivo, a necessidade de aumentar ou diminuir a dose de insulina.

A glicohemoglobina também possibilita, além das glicemias capilares, fazer um bom controle do metabolismo do paciente e deve ser realizada de três em três meses.

A dieta é muito necessária para fazer o ajuste da dosagem de insulina a ser administrada no paciente e também fazer o controle glicêmico.

Embora as restrições alimentares sejam a queixa principal dos pacientes e da família, o controle alimentar deve ser tratado individualmente e, por isso, se faz necessária e fundamental a orientação do nutricionista. 
O exercício físico, com o acompanhamento sistemático, favorece o controle do metabolismo. A harmonização da dose de insulina e a alimentação adequada previnem a hipoglicemia. A queda da glicose pode ocorrer durante e até 15 horas, depois da atividade física.

Os pacientes devem ser rigorosamente acompanhados e orientados em relação ao exercício físico e a averiguação da glicemia capilar deve ser feita antes e após as atividades. O resultado do exame poderá indicar mudanças no tratamento, conforme Silva et al (2004, p. 19). “... O exercício físico desencadeia uma reação neuroendócrina, que resulta na liberação dos hormônios contrarreguladores. Quando o controle metabólico está inadequado, o exercício pode precipitar uma cetoacidose".

O exercício pode acelerar uma cetoacidose, quando o controle metabólico não está adequado. A cetoacidose é a complicação da diabetes mellitus que resulta da dosagem inadequada de insulina no organismo do paciente. “... os pacientes com controle metabólico inadequado estão mais susceptíveis à ação dos hormônios contrarreguladores e, portanto, ao desenvolvimento da hiperglicemia e cetose, e à progressão para a cetoacidose e para o coma". (SILVA ET AL, 2004, p.21)

Por tudo exposto, o tratamento do paciente deve ser feito no hospital, com o acompanhamento clínico e laboratorial de maneira sistemática. A anotação dos dados clínicos e laboratoriais, bem como o registro das medicações ministradas ao paciente, como soro e insulina são importantes. "O tratamento compreende a hidratação do paciente, a correção da acidose e a insulinoterapia, realizadas simultaneamente. Possíveis fatores desencadeantes devem ser pesquisados e abordados (infecção, febre, dor, etc.) ". (SILVA ET AL, 2004, p.22)

A avaliação do nível de desidratação deve ser cuidadosa e pode se desdobrar em: reparação rápida, reparação lenta ou manutenção. O tempo de duração de cada fase de hidratação é referência para a conduta no tratamento e, por isso, deve ser submetido à avaliação da clínica médica.

É possível fazer a correção da acidose metabólica através da insulinoterapia e da administração de glicose.

Quanto à insulinoterapia, embora a preferência seja de administração da insulina via endovenosa, poderá ocorrer também via intramuscular ou subcutânea. "A escolha da via de administração deve levar em consideração a experiência da equipe médica e de enfermagem, a disponibilidade da bomba de infusão e de 
acesso venoso (que deve ser exclusivo para a infusão da insulina) ". (SILVA ET AL, 2004, p. 24)

A dosagem de insulina deve ser realizada no ambulatório e a permanência do paciente no hospital se justifica apenas para o controle da glicemia.

O paciente deve ser avaliado continuamente durante todo o tempo de tratamento, pois, as possíveis complicações devem ser detectadas e tratadas, o quanto antes.

A complicação da insulinoterapia ocorre em quase todos os pacientes, caracterizando a hipoglicemia. O nível excessivo de insulina, a alimentação insuficiente e o exercício físico podem ocasionar a hipoglicemia.

As crianças menores de sete anos e, mais especificamente as menores de três anos, são mais suscetíveis à hipoglicemia, em decorrência do período de desenvolvimento do sistema nervoso central.

É preciso ter atenção aos sintomas do paciente.

A sintomatologia decorrente da neuroglicopenia consiste em alterações do
estado de consciência e do comportamento, convulsões, distúrbios visuais,
fome. A resposta neuroendócrina à hipoglicemia provoca um aumento dos
hormônios contrarreguladores. Os sintomas desencadeados por essa
resposta são palidez, tremores, taquicardia, sudorese, náuseas e vômitos.
O diabético pode apresentar esses sinais e sintomas quando a glicemia
sofre uma redução brusca, mesmo sem a ocorrência de hipoglicemia.
(SILVA ET AL, 2004, p. 26)

A comunidade na qual o paciente está inserido deve ter aptidão para reconhecer e tratar a hipoglicemia. Portanto, a participação da família, da escola e dos amigos do paciente, é muito importante para o sucesso do tratamento. "[...]. Se possível, a glicemia capilar deve ser verificada, para confirmação da hipoglicemia. $O$ tratamento consiste na administração de açúcar ou líquidos açucarados. " (SILVA ET AL, 2004, p. 27)

A equipe de enfermagem tem contato mais próximo com o paciente e sua família, pois, ajuda o paciente no desenvolvimento do autocuidado, até que este tenha condição de assumir a responsabilidade de lidar com suas necessidades básicas, como sua saúde.

[...] a assistência de enfermagem prestada à criança e adolescentes com diabetes mellitus tipo 1 atendidos no ambulatório de endocrinologia do Hospital das Clínicas da UFMG tem ênfase nas ações educativas e na promoção do autocuidado como instrumentos imprescindíveis ao alcance do bom controle metabólico. 
A equipe de enfermagem é composta por 01 enfermeiro, 01 técnico de enfermagem e um auxiliar de enfermagem, estando inserida numa equipe multiprofissional que atende, em média, 40 pacientes por semana. (SILVA ET AL, 2004, p. 27)

A enfermagem tem como objetivos principais: a promoção da assistência de enfermagem para auxiliar o controle do paciente; a promoção da educação continuada para o autocuidado do paciente; e a promoção da educação continuada de profissionais da enfermagem.

O trabalho da enfermagem consiste em atuar de maneira educativa e assistencial.

As atividades educativas compreendem a orientação individual e em grupo. $\mathrm{Na}$ orientação individual o enfermeiro educador promove três ou quatro encontros para abordar temas que são primordiais, como:

[...] conceito de diabetes, insulinoterapia, prevenção, detecção e cuidados nas complicações, testes de glicemia capilar, glicosúria e cetonúria, manuseio do mapa de controle glicêmico domiciliar, alimentação adequada, cuidados com o corpo e exercício físico. (SILVA ET AL, 2004, p. 28)

No grupo educativo, chamado também de grupo de controle, o objetivo é trabalhar os conceitos de maneira mais didática, promovendo a discussão de experiências distintas de cada participante, em um ambiente lúdico. Os participantes são crianças e adolescentes acima de sete anos e membros da equipe multiprofissional. Respectivamente, o grupo de pais conta com os recursos disponíveis para o grupo dos filhos acompanhados.

Em alguns momentos, o grupo educativo é planejado em forma de curso, com participação de 05 a 10 pacientes, tendo como finalidade rever os conceitos dados no início do tratamento, segundo o seguinte programa:

$>$ Conceito de DM TIPO1 e complicações agudas.

$>$ Insulinoterapia.

$>$ Complicações crônicas e cuidados com o corpo.

$>$ Dietoterapia e exercício físico. (p. 29)

Os temas são trabalhados através de uma linguagem fácil e compreensível aos pacientes e seus familiares, de modo que haja um efeito positivo no tratamento.

As atividades assistenciais compreendem: testes pré consulta, administração de insulina supervisionada, consulta de enfermagem, acompanhamento via telefone, atendimento às urgências e visita domiciliar. 
Nos testes pré consulta, são feitos "os testes de glicemia capilar, glicosúria e cetonúria pelo auxiliar, técnico de enfermagem e enfermeiro presentes durante 0 atendimento do paciente." (Silva et al, 2004, p.29). Pode ser preciso que o profissional enfermeiro faça a avaliação do mapa de controle da glicemia em ambiente domiciliar.

$\mathrm{Na}$ administração da insulina supervisionada, o enfermeiro supervisiona o procedimento realizado pelo próprio paciente ou responsável. É uma oportunidade para avaliar o aprendizado quanto à insulinoterapia.

A consulta de enfermagem tem como objetivo avaliar a saúde do paciente no início do tratamento e orientá-lo quanto as suas necessidades básicas para que conjuntamente sejam apontadas condutas para o bem-estar do diabético. Podem ocorrer também nos intervalos das consultas médicas quando:

$>$ É preciso reajustar a dose ou introduzir insulina regular;

$>$ Inexiste adesão ao tratamento e o assistido ou seu responsável precisam ser submetidos à reciclagem do processo educativo;

O assistido que comparece ao ambulatório apresenta complicações.

O acompanhamento via telefone facilita a comunicação do enfermeiro com o paciente e/ou seu responsável, caracterizando assim, mais recurso para alcançar e orientar o assistido.

No atendimento às urgências Silva et al (2004, p. 30) ensinam que o enfermeiro faz uma primeira avaliação, em seguida, encaminha o paciente ao endocrinologista de plantão. "[...] Na ausência do médico, o enfermeiro faz contato direto como o coordenador médico do Pronto Atendimento do Hospital das Clínicas (PA) afim de promover o encaminhamento do paciente. [...]". Se necessário, o enfermeiro dá início ao atendimento no ambulatório, de acordo com a urgência.

As visitas domiciliares acontecem para orientar os assistidos e/ou seus responsáveis quanto às dificuldades para executar as orientações "ou quando as condições biopsicossociais estão dificultando a aderência ao tratamento. " (Silva et al, 20047, p.30). São objeto de orientação os seguintes temas:

> Orientação sobre DM tipo 1 ao paciente e familiares.

$>$ Local de acondicionamento da insulina e condições dos equipamentos utilizados na sua administração e realização do auto-cuidado.

$>$ Condições de alimentação.

> Localização da residência em relação às unidades de saúde, escola, associações comunitárias do bairro.

$>$ Avaliação das condições de moradia: rede de esgoto, luz e água. 
$>$ Lazer da família.

$>$ Avaliação da dinâmica familiar. (SILVA ET AL, 2004, p. 30 e 31)

Os profissionais que ajudam no autocuidado precisam estimular a comunicação e interação dos pacientes com eles e com os as outras pessoas que fazem parte do universo do assistido. Isto aprimora a eficácia do tratamento.

A equipe de enfermagem registra que enfrenta problemas no atendimento à criança e adolescente diabéticos, no ambulatório do Hospital das Clínicas, que decorrem de "desarmonia familiar, baixo padrão socioeconômico, analfabetismo e falta de recursos materiais e físicos. " (SILVA ET AL, 2004, p. 31)

Contudo, a equipe de enfermagem considera que estas dificuldades são inerentes da oferta de um serviço público, por isso, a utilização de estratégias para alcançar objetivos importantes é essencial. Neste sentido, a integração da equipe multiprofissional, o bom atendimento e infraestrutura pertinentes, são fundamentais.

A equipe de nutrição trabalha a dieta do paciente. "O sucesso do tratamento do diabetes tipo 1 está intimamente ligado a três fatores de fundamental importância: insulinoterapia, prática de exercício físico e dieta. (SILVA ET AL, 2004, p. 32)

A dieta do diabético é um fator complexo de ser trabalhado, pois implica em mudanças de hábitos relacionados à alimentação. Trata-se não apenas de alteração da forma de se alimentar, contudo, de mudanças relacionadas "à essência do indivíduo. " (SILVA ET AL, 2004, p. 32)

É importante que seja realizado um acompanhamento dietético com objetivo de controlar a glicemia, prevenir as complicações do diabetes e garantir um desenvolvimento normal ao paciente. Para que estes três objetivos sejam alcançados, é fundamental o controle dietoterápico do diabético, que compreende:

> Avaliação do estado nutricional do paciente segundo parâmetros antropométricos, bioquímicos e clínicos.

> Avaliação da ingesta habitual do paciente através de recordatório alimentar de $24 \mathrm{~h}$, visando adequar ingesta do paciente as suas preferências e poder aquisitivo e identificar deficiências referentes ao hábito alimentar do paciente.

> Confecção de cardápio alimentar compatível com necessidades nutricionais do paciente, hábitos e poder aquisitivo.

$>$ Orientações dietéticas. (SILVA ET AL, 2004, p. 32)

Para que o acompanhamento seja profícuo, na primeira consulta com o nutricionista é feita a avaliação nutricional, a avaliação da ingesta e ainda, procedidas as orientações dietéticas. Depois, é realizado o retorno, "onde o paciente 
recebe o cardápio alimentar compatível com suas necessidades, lista de substituição de alimentos (visando evitar monotonia do cardápio) e reforço das orientações dietéticas. " (Silva et al, 2004, p. 33). Os retornos subseqüentes são agendados conforme necessidade, considerando a melhora ou piora da glicemia, condição nutricional, etc.

Mais do que fazer o acompanhamento individual, é preciso oferecer ao paciente, possibilidades para que ele interaja no meio social. É preciso que o diabético além de conhecer as limitações da doença, desperte para os prazeres da vida. "Enfim, tem-se que "inventar" formas de se fazer o paciente diabético ver a dieta não como uma punição, mas como um meio valioso de se melhorar sua qualidade de vida. " (SILVA ET AL, 2004, p. 33)

Por isso, o trabalho do profissional competente, seja individualmente ou em grupo, é muito importante para estimular o paciente e seus familiares.

A equipe de psicologia lida com o diagnóstico e o tratamento da pessoa com diabetes, considerando todos os aspectos importantes para o paciente. Neste sentido, muito necessária é a integração da equipe multiprofissional.

\begin{abstract}
É nesse contexto que a assistência psicológica complementa o empenho de todos os membros da equipe, visando o trabalho preventivo e a atenção global ao indivíduo, identificando estresses específicos com os quais os diabéticos e seus familiares têm que se confrontar conforme cada etapa do desenvolvimento da criança ou adolescente. (SILVA ET AL, 2004, p.34)
\end{abstract}

As condições materiais como insulina, exames e dietas, e ainda 0 conhecimento dos cuidados pertinentes a doença, não são bastam para afirmar a adesão do paciente ao tratamento. A diabetes tem impacto não só no corpo, mas na área emocional, sócio-cultural, no ambiente familiar e no psiquismo do indivíduo. São transtornos, rompimentos e perdas que ultrapassam os danos físicos, como os prejuízos da função do pâncreas.

O psicólogo tem como objetivo trabalhar questões relacionadas com a subjetividade. "Oferecer um espaço para que estas pessoas possam construir um sentido para sua doença, relacioná-la com outros fatos de sua vida e incluí-la em usa história pessoal, tornando-se assim, sujeito de sua doença e não assujeitado por ela" (SILVA ET AL, 2004, p. 35)

O público alvo do trabalho do profissional da psicologia compreende crianças e adolescentes até 20 anos, pais e familiares. 
O paciente pode apresentar necessidade de ser atendido individualmente ou por meio de:

> Participação em grupos educativos multiprofissionais semanais de crianças e adolescentes. Os encontros buscam trabalhar não só aspectos pedagógicos, assim como aspectos subjetivos e objetivos relacionados a sentimentos, atitude, auto-estima, inter-relações familiares e outras questões, favorecendo a elaboração dos mesmos.

> Participação em grupos educativos multiprofissionais semanais de pais e/ou familiares com a devida escuta para os aspectos subjetivos e objetivos envolvidos no processo de "adoecimento familiar". Trata-se de criar a oportunidade para troca de experiências vivenciadas pelos diversos núcleos familiares, trabalhando as angústias, medos, culpas e questões que possibilitam a elaboração desse "adoecer".

> Participação em encontros/discussões com toda a equipe propiciando um pensar e repensar coletivos, onde possam emergir novas percepções e significados do que vem a ser a doença crônica para os diferentes casos. (SILVA ET AL, 2004, p. 35)

A equipe de assistência social tem como objetivo "... a interação família/diagnóstico/família/cliente família/equipe" (SILVA ET AL, 2004, p. 36).

Ao trabalhar as varias dimensões que acercam o individuo utilizam os indicadores de ordem emocional, social, cultural e econômica. Baseando-se nestes indicadores a Assistência Social tem como premissa:

$>$ Orientar, informar e encaminhar os familiares do cliente aos recursos existentes na rede de saúde fornecendo-lhes dados sobre associações específicas.

$>$ Identificar e intervir nos problemas e riscos sociais que possam resultar em prejuízo para o tratamento.

$>$ Realizar entrevistas (sociais e estudo de caso), objetivando o conhecimento da realidade sócio familiar e o acompanhamento das famílias que necessitarem de intervenção do Serviço Social.

$>$ Realização de visitas domiciliares (utilizando protocolo abaixo) e às instituições da rede de saúde para que possa ser criada uma rede de atendimento completa, visando a orientação familiar e institucional, atendendo o cliente como um todo.

$>$ Participação no grupo de pais para que haja um momento onde os familiares possam estar sendo ouvidos e que possam discutir suas dificuldades visando a criação de um vínculo entre eles. (SILVA ET AL, 2004, p. 37)

Nesse contexto, observa-se que a família constrói um processo fantasioso da doença com perspectiva de abrandar o contexto patológico em que se vêem inserida, pois, desta forma a realidade se aproxima pode parecer mais próxima da imaginação. Contudo, cada família reage de uma forma, não sendo possível generalizar, devendo se considerar o contexto histórico de cada uma delas, sua inserção na sociedade e todo o cuidado dispensado a criança e ao adolescente. 


\section{CAPÍTULO III - METODOLOGIA}

\subsection{Tipo de Pesquisa}

Trata-se de uma revisão integrativa da literatura, considerada um método de estudo que possibilita a síntese do conhecimento de um determinado assunto, além de apontar lacunas, que precisam ser preenchidas com a realização de novos estudos.

O estudo comporta a abordagem qualitativa em pesquisa, que segundo Rodrigues (2006) não emprega procedimentos estatísticos, pois não estabelece este procedimento como objetivo principal. Está mais voltada para as situações em que os procedimentos estatísticos não podem alcançar ou representar como é o caso desta pesquisa.

Ainda Godoy (1995) ressalta que as características principais de uma pesquisa qualitativa são: o ambiente como fonte direta dos dados e o pesquisador como instrumento chave; possui caráter descritivo; o processo é o foco principal de abordagem e não o resultado ou o produto.

A Pesquisa descritiva a utilizada no presente estudo "... tem como objetivo primordial a descrição das características de determinada população ou fenômeno ou o estabelecimento de relações entre variáveis". (GIL, 2008, p.28).

Quanto à técnica de coleta de dados, a pesquisa utilizada é a bibliográfica, baseando-se em livros, artigos já publicados do assunto em questão. "A principal vantagem da pesquisa bibliográfica reside no fato de permitir ao investigador a cobertura de uma gama de fenômenos muito mais ampla do que aquela que poderia pesquisar diretamente. (GIL, 2008, p.51).

A abordagem da pesquisa qualitativa e descritiva permite responder às questões relacionadas à percepção dos indivíduos em relação à ação educativa, bem como, possibilita entender as melhores intervenções desenvolvidas, com vistas à promoção da saúde e a possibilidade de documentar se houve mudança no comportamento dos indivíduos após a participação no processo educativo.

Para o desenvolvimento da presente revisão serão percorridas as seguintes etapas: estabelecimento da questão norteadora; seleção dos artigos e critérios de inclusão; extração dos artigos incluídos na revisão; avaliação dos estudos incluídos; interpretações dos resultados, e apresentação da revisão integrativa. 


\subsection{Variáveis}

\subsubsection{Definição Conceitual}

A forma de coleta de dados adequados na pesquisa bibliográfica é fundamental para realização de uma boa pesquisa, permitindo uma melhor interação entre pesquisador e a literatura, auxiliando-o na análise dos textos.

O levantamento de dados é o alicerce no qual se fundamenta o material valioso nas estratégias de pesquisa. Sistematicamente, reúne-se informações através de coleta contínua dos dados sobre os dados, a fim de evidenciar o problema em foco.

A coleta de dados ao fundamentar a sistematização da assistência da equipe multidisciplinar, possibilita a aplicação de seus conhecimentos técnico-científicos que embasam a profissão. Uma adequada coleta de dados deve oferecer subsídios para investigar as informações de forma clara, objetiva e sistematizada, a fim de facilitar na identificação de diagnósticos coerentes com as necessidades do cliente.

A utilização de modelos teóricos é importante para nortear a elaboração do instrumento de coleta de dados.

Do ponto de vista das práticas cotidianas, "autocuidado" significa um conjunto de ações mobilizadas pelas próprias pessoas, de modo espontâneo e sistemático, para sustentação de sua própria sobrevivência. Crianças e adolescentes têm certas dificuldades de exercício de autocuidado. Compreendendo que as recomendações de orem estão incluídas no rol das atividades de vida, considerou-se para efeito dessa pesquisa apenas esse último modelo.

A pesquisa ampara-se na leitura e análise referencias teóricos, permitindo a deteç̧ão das informações básicas que ancoraram os passos da pesquisa.

\subsubsection{Definição Operacional}

Os textos foram submetidos a um exame prévio, que nos deu uma visão de conjunto. Nesse exame observou-se certos detalhes, que parecem insignificantes apenas para aqueles que não têm o habito da leitura intelectual. Entre os referidos detalhes temos: título, subtítulo, nome do autor e sua situação profissional, editora, 
ano e local da publicação, número da edição, sumário, índice, bibliografia, prefácio, apresentação etc., e as informações contidas nas orelhas.

Iniciou-se a leitura pelo nível exploratório para evitar uma série de erros muito frequentes, entre os quais concluir que não se trata de publicação adequada para os fins que se têm em vista; que o autor tem pouco ou nenhum crédito entre os especialistas da área para sustentar os argumentos.

Depois o pesquisador buscou a leitura interpretativa para saber o que os autores realmente afirmam e quais os dados que oferecem às informações que transmitem. Relacionou o que o autor afirma com relação ao problema em estudo procurando a solução. $O$ julgamento de idéias se fizeram em função dos propósitos do pesquisador, aplicando-se na solução do problema; finalmente o material coletado foi julgado em função critério verdade.

\subsection{Instrumentos}

Textos completos disponíveis online, no período de 2000 a 2015, dos quais, os resumos descrevem práticas educativas desenvolvidas para crianças e adolescentes de ambos os sexos com diabetes mellitus tipo 1 e cujos dados coletados objetivaram uma análise.

\subsection{Coleta de Dados}

As seguintes bases de dados eletrônicos: Literatura Latino Americana em Ciências da Saúde (LILACS), Medical Literature end Retrieval System on Line (Medline), Índice Bibliográfico Español en Ciencias de la Salud (IBECS) e a Base de Dados em Enfermagem (BDENF). Empregaram-se os Descritores em Ciências da Saúde (DeCS): educação em saúde e Diabetes Mellitus.

\subsection{Tratamento dos Dados}

A análise dos dados foi realizada de forma indutiva pelo pesquisador; não requereu o uso de técnicas e métodos estatísticos; e, por fim, teve como preocupação maior a interpretação da literatura e a atribuição da conclusão, o que caracteriza, também, a pesquisa em pauta. 


\section{CAPÍTULO IV - CONCLUSÃO}

Os artigos escolhidos possuíam as temáticas frente a questão norteadora do trabalho em questão. Já os excluídos não possuíam as variáveis necessárias para a realização do trabalho. Ambos estão apresentados na tabela e no gráfico abaixo:

Tabela 4 - Artigos Incluídos e Excluídos

\begin{tabular}{crr}
\hline & Incluídos & Excluídos \\
\hline 2000 & 1 & 0 \\
2002 & 1 & 0 \\
2003 & 1 & 0 \\
2005 & 1 & 1 \\
2006 & 1 & 1 \\
$\mathbf{2 0 0 7}$ & 3 & 1 \\
$\mathbf{2 0 0 8}$ & 6 & 2 \\
$\mathbf{2 0 0 9}$ & 2 & 0 \\
\hline 2010 & 1 & 0 \\
$\mathbf{2 0 1 1}$ & 7 & 0 \\
$\mathbf{2 0 1 2}$ & 1 & 2 \\
\hline 2013 & 5 & 0 \\
\hline 2014 & 2 & 1 \\
\hline Fonte: Elaborado pela autora (2016)
\end{tabular}

Gráfico 1 - Artigos Incluídos e Excluídos

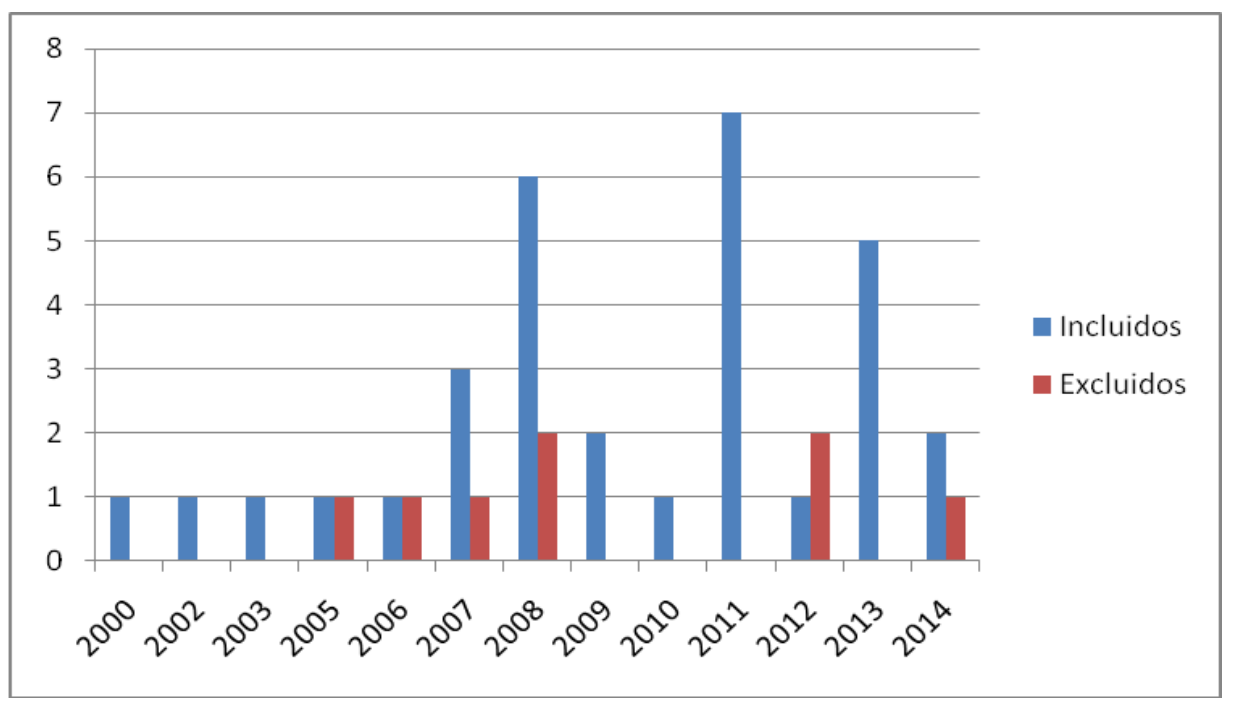

Fonte: Elaborado pela autora (2016) 
A baixa quantidade de artigos ocorreu pelo fato de não existir um alto índice na literatura de textos específicos, isto é, da Diabetes Mellitus Tipo 1 e principalmente sobre a questão da educação.

\section{A Multiprofissionalidade do Cuidado com o Paciente Diabético Tipo I:} Uma Experiência. DAMO, Nevoni Goretti et al. Objetivo: Relatar a experiência da atuação conjunta de profissionais da saúde no atendimento de um grupo de crianças/adolescentes acometidos de diabetes tipo I. Este relato apresenta a experiência da integração ensino-serviço-comunidade, vivenciado por profissionais da academia de Odontologia, Farmácia, Medicina e Serviço Social, por meio de dois projetos de extensão, cujo objetivo principal consistiu em manter a saúde geral e oral de crianças e adolescentes portadores de Diabetes Mellitus tipo I com ênfase na educação para saúde. Resultado: Esta experiência trouxe benefícios para o paciente, aprimorando o engajamento para o autocuidado, e, para a academia, ampliou os espaços de oportunidades para a troca de conhecimentos entre docentes e discentes.

A responsabilidade social da enfermagem frente à política da humanização em saúde. TRENTINI, Mercedes et al. Objetivo: Refletir sobre a política de humanização como parte da Promoção da Saúde com destaque no cuidado de enfermagem. Resultados: A escuta sensível, as modalidades de diálogos, o método da entrevista-conversação, são tecnologias das relações e significa a aquisição de competências à política da humanização para o desenvolvimento do cuidado na promoção da saúde.

A experiência de jogos em grupos operativos na educação em saúde para diabéticos. TORRES, Heloisa de Carvalho et al. Objetivo: O presente trabalho descreve e discute uma estratégia educativa desenvolvida em ambulatório de especialidade, cujo objetivo é estimular o indivíduo a refletir sobre seu estilo de vida cotidiano relacionado à sua patologia, no caso específico diabetes mellitus, caracterizando-se como um instrumento de educação em saúde sob uma perspectiva de promoção, prevenção e controle. Metodologia: Para tal, foi implementada uma dinâmica de interação profissional-indivíduo, que teve por base o uso de jogos educativos em grupos operativos. As técnicas pedagógicas utilizadas para a sistematização da dinâmica foram: curso de orientação em diabetes mellitus, consulta individual, grupo operativo e uso de material educativo de comunicação e 
aprendizagem (jogo). Resultados: Essas técnicas possibilitaram a construção do conhecimento pelos participantes, a troca de vivências entre os mesmos, além do entendimento da experiência individual da doença pelo profissional de saúde.

Abordagem do Diabetes Melitto na Primeira Infância. CALLIARI, Luis Eduardo P. e MONTE, Osmar. Artigo de revisão abordando a Diabetes em todos os seus aspectos.

Abordagem interdisciplinar no tratamento do diabetes mellitus tipo 2: da teoria à prática. COSTA, Mônica Barros e CASTRO, Antônio Paulo Andre de. Objetivo: Relatar a experiência do projeto de extensão universitária "Acompanhamento, Educação e Prevenção em Diabetes Mellitus" do Serviço de Endocrinologia do Hospital Universitário da Universidade Federal de Juiz de Fora, Minas Gerais.

Apreender as repercussões do diabetes mellitus em crianças sob a ótica das mães. CORREIA JR, Paulo Cesar Teles. Objetivo: Apreender as repercussões do Diabetes Mellitus em crianças e na vida familiar sob a ótica do cuidador principal. Metodologia: Pesquisa descritiva com abordagem qualitativa, realizada com sete mães acompanhadas em um centro de referência do município do Crato, CE, Brasil, nos meses de junho e julho de 2011. Resultados: Foram apreendidas mudanças comportamentais das crianças, tais como: agressividade, sentimentos de negação e medo. Observou-se ainda, que os cuidados das crianças diabéticas recaem sobre a mãe. Desta forma, percebe-se a necessidade de implantação de uma assistência multiprofissional, interdisciplinar e humanizada, direcionada aos pacientes com Diabetes Mellitus e seus cuidadores, com ênfase na educação em saúde.

Aspectos Emocionais de Crianças Diabéticas: experiência de atendimento em grupo e Reflexões sobre o Diabetes Tipo 1 e sua Relação com - Emocional. MARCELINO, Daniela Botti e CARVALHO, Maria Dalva de Barros. Metodologia: Este trabalho levantou dados bibliográficos que subsidiassem reflexões sobre os aspectos emocionais vivenciados pelas crianças diabéticas. Objetivo: O diabetes tipo 1 ou infanto-juvenil. Tendo em vista as repercussões que esta doença crônica traz. Resultados: O resultado mostrou que o emocional influi na etiologia do diabetes e que o diabetes também influi no emocional desta criança.

Assistência às crianças com Diabetes tipo 1 na visão da família: uma abordagem qualitativa. MARCON, Sonia Silva et al. Objetivo: Conhecer os recursos utilizados pelas famílias na assistência às crianças diabéticas tipo 1 . 
Metodologia: Trata-se de um estudo descritivo exploratório de natureza qualitativa realizado com sete famílias residentes em Maringá-PR, cujos filhos menores de 14 anos eram cadastrados nas Unidades Básicas de Saúde do município como portadores de diabetes mellitus tipo 1. Os dados foram coletados em maio de 2007 por meio de entrevistas semi-estruturadas realizadas no domicílio das famílias. Resultados revelaram que na avaliação das famílias, a criança com diabetes mellitus necessita de assistência diferenciada e que esta não é oferecida pelo setor público, obrigando-as a assumir os custos com um plano de saúde, mesmo sem ter condições financeiras para isto. Em relação à assistência no setor público, queixamse da dificuldade para um atendimento de emergência, da demora para conseguir consulta com especialistas e para a realização de exames e apontam a ausência/distância do profissional enfermeiro na Equipe de Saúde da Família (ESF), especialmente por ocasião das visitas domiciliares, o que repercute negativamente no processo educativo junto as mesmas.

Avaliação do cotidiano e enfrentamento de adolescentes com diabetes mellitus tipo 1. CORRER, Rinaldo et al. Objetivo: O presente estudo visa identificar e analisar as principais características emocionais que possam afetar 0 funcionamento psíquico de adolescentes com DM1. Metodologia: Participaram 8 adolescentes atendidos na Associação dos Diabéticos de Bauru. Como estratégia metodológica utilizou-se a pesquisa qualitativa de caráter exploratório e descritivo. Foi utilizada entrevista semiestruturada com questões referentes à percepção da história pregressa e o futuro, metapercepção e imagem corporal, que compreendem aspectos ligados à identidade dos adolescentes. Resultados: Os resultados permitem considerar que o DM1 altera a dinâmica familiar em aspectos biológicos, psicológicos e sociais, configurando elementos que interferem no enfrentamento da doença. Isso gera conflito, medo, insegurança e superproteção, que interferem na identidade do indivíduo.

\section{Caracterização de crianças e adolescentes com Diabetes Tipo 1 em} seguimento terapêutico. ZANETTI, Maria Lúcia e MENDES, Isabel Amélia Costa. Objetivo: Estudo descritivo com mães de crianças e adolescentes portadores de diabetes tipo 1, com o objetivo de caracterizar crianças e adolescentes diabéticos tipo 1, matriculados em escolas de $1^{\circ}$ e $2^{\circ}$ grau, públicas e particulares, durante 0 seguimento terapêutico. Metodologia: Para o alcance dos objetivos realizamos entrevista dirigida. Resultados: que a maioria (83,3\%) é portadora da doença há 
mais de cinco anos; (93,3\%) sofreram internações hospitalares, sendo a hiperglicemia o motivo mais freqüente (46,7\%). Também apontam para a necessidade de desenvolvimento de eqüidade no atendimento às famílias de crianças e adolescentes diabéticos tipo 1, fornecendo apoio e suporte para que estas possam lidar com a criança portadora de doença crônica.

Cetoacidose Diabética em Crianças: Perfil de Tratamento em Hospital Universitário. CASTRO, Lelma et al. Objetivo: Avaliar as características de crianças com cetoacidose diabética (CAD) tratadas no Hospital de Clínicas da UNICAMP. Metodologia: Estudo retrospectivo e descritivo de variáveis clínicas e laboratoriais de 74 internações por CAD em 49 pacientes no período de janeiro de 1994 a dezembro de 2003. Resultados. Na amostra estudada houve predomínio de pacientes do sexo feminino, abaixo de 10 anos, com manifestação grave da doença, porém com boa evolução e poucas complicações. As internações corresponderam, em sua maioria, a um pequeno número de pacientes.

Como os profissionais da atenção primária percebem e desenvolvem a Educação Popular em Saúde? FLISCH, Tácia Maria Pereira et al. Objetivo: analisar percepções e experiências em Educação em Saúde de 166 profissionais de equipes de Saúde da Família de Contagem (MG, Brasil). Metodologia: 166 profissionais de equipes de Saúde da Família de Contagem (MG, Brasil) responderam um questionário sobre práticas de Educação em Saúde. Resultados: Os participantes consideraram aspectos além da finalidade informativa, ao relatar práticas voltadas à qualidade de vida e à formação humana. Todas as categorias profissionais mencionaram uma maior participação em grupos de controle da hipertensão arterial sistêmica e diabetes mellitus. Utilizam a pedagogia de Paulo Freire 4,7\% dos entrevistados. Termos que demonstram a intencionalidade política, como "controle social" e "Educação Popular em Saúde" não foram mencionados. Foi constatada a necessidade de processos de educação permanente para os profissionais e implementação da política nacional de Educação Popular em Saúde.

Crianças e adolescentes com Diabetes Mellitus: Cuidado/Implicações para a Enfermagem. FIALHO, Flávia Andrade et al. Metodologia: Trata-se de uma pesquisa qualitativa, na qual foram entrevistadas 15 crianças/adolescentes usuárias do Serviço de Controle de Hipertensão, Diabetes e Obesidade da Secretaria Municipal de Saúde de Juiz de Fora Objetivo: descrever a percepção da criança e 
do adolescente em ser portador de diabetes mellitus tipo 1 e discutir de que forma enfrentam a situação. Resultados: Os resultados mostraram que, para o enfrentamento do diabetes mellitus, é preciso esforços conjuntos da criança/adolescente diabético, das famílias e dos profissionais de saúde, para que os portadores atinjam um bom controle metabólico.

Diabetes Melito: Diagnóstico, Classificação e Avaliação do Controle Glicêmico. GROSS, Jorge L et al. Artigo de atualização.

Diabetes Melittus juvenil: a experiência de familiares de adolescentes e pré-adolescentes. BRITO, Thais Basso de e SADALA, Maria Lúcia Araújo. Objetivo: investigar a experiência de cuidar de adolescentes e pré-adolescentes portadores de diabetes tipo I, na perspectiva dos seus familiares. Metodologia: Foi utilizada a abordagem fenomenológica, modalidade de pesquisa qualitativa que se propõe a compreender os significados das experiências vividas. Foram entrevistados dez pais (9 mães e 1 pai) em hospital de ensino do interior paulista.Resultados: Eles acreditam que têm que aceitar e enfrentar os desafios, além de estimularem os filhos para sua segurança e qualidade de vida. Os dados mostraram a necessidade de um suporte profissional, além de um espaço para a discussão de temas tanto para as crianças com diabetes como para seus familiares.

Diabetes Melito Tipo 1: da Pesquisa à Clinica. DIB, Sergio Atala et al. Editorial.

Diabetes Melittus Tipo 1: multifatores que conferem suscetibilidade à patogenia auto-imune. SESTERHEIM, Patrícia et al. Objetivo: Revisar dados de literatura concernentes aos fatores que conferem suscetibilidade à patogenia autoimune do diabetes mellitus tipo 1. Metodologia: Revisão de artigos especializados no assunto publicados em bancos de dados nacionais e internacionais (SCIELO, LILACS e PUBMED). Resultados: o diabetes mellitus tipo 1 é uma entidadede etiopatogenia altamente complexa. Diversos fatores genéticos e ambientais potencializam os mecanismos de auto-imunidade humoral e celular que levam à insulite.

Diabetes mellitus tipo 1: evidências da literatura para seu manejo adequado, na perspectiva de crianças. NASCIMENTO, Lucila Castanheira et al. Objetivo: identificar as evidências disponíveis, na literatura, que abordem, na perspectiva de crianças, os fatores relevantes para o adequado manejo do diabetes mellitus tipo 1. Metodologia: Realizou-se uma revisão integrativa, nas bases de 
dados PubMed, CINAHL, LILACS, CUIDEN e PsycINFO, com as palavras-chave diabetes mellitus tipo 1, criança, prevenção e controle, fatores desencadeantes, emergências, autocuidado, aprendizagem e educação em saúde, no período de 1998 a 2008. Resultados: As evidências apontam que a criança aprecia o apoio recebido por seus familiares os quais têm relação direta com o preparo para 0 autocuidado. Outros membros externos à sua rede também são valorizados. A escola é um espaço que merece atenção, bem como a experiência particular de cada criança e a educação em saúde.

Dificuldades dos pacientes diabéticos para o controle da doença: sentimentos e comportamentos. PERES, Denise Siqueira et al. Objetivo: identificar as dificuldades dos pacientes diabéticos em relação ao tratamento para o controle da doença. Metodologia: Participaram 24 diabéticos acompanhados no Centro Educativo de Enfermagem para Adultos e Idosos, em 2003. Para obtenção dos dados utilizou-se de relato escrito, de forma individual, em dia pré-determinado, a partir de uma questão norteadora previamente elaborada. Na análise dos dados, utilizou-se a técnica de análise de conteúdo. Resultados: mostraram que são inúmeras as dificuldades relacionadas ao seguimento do tratamento: rejeição e negação da condição de doente, sofrimento e revolta devido às restrições impostas pela alimentação, atividade física e medicamento. É possível inferir que o enfoque da abordagem educativa não deve se restringir apenas à transmissão de conhecimentos, mas é importante englobar os aspectos emocionais, sociais e culturais que influenciam no seguimento do tratamento.

Escala comportamental de suporte social familiar para adolescentes com diabetes (dfbs). ALMEIDA, Paulo \& PEREIRA, M. Graça. Objectivo: adaptação da Escala Comportamental de Suporte Social Familiar na Diabetes (DFBS) Metodologia: Amostra de 256 adolescentes com Diabetes Tipo 1. Resultados: Os resultados apontam para uma composição da escala em 33 itens, organizados em 2 componentes: Controlo-Aconselhamento e Afecto, que explicam $33.3 \%$ da variabilidade, apresentando cada subescala um alfa de .76 e .81, respectivamente, e a escala total um alfa de .91 .

Estratégias educativas ao portador de diabetes mellitus: revisão sistemática. PEIXOTO, Gilciane Vianna Peixoto e SILVA, Rosângela Marion da. Objetivo: Identificar as estratégias utilizadas para realizar ações educativas em saúde ao portador de Diabetes Mellitus. Metodologia: A busca dos artigos foi 
realizada de maio a junho de 2010, nas bases de dados LILACS e SCIELO e utilizou como descritores: Diabetes Mellitus, Educação em saúde, Enfermagem em saúde comunitária e Enfermagem. Resultados: evidenciaram como estratégias para promover a qualidade de vida do portador de Diabetes Melittus, a realização de ações educativas com a participação multiprofissional, a inclusão da família no tratamento e a realização de atividades em grupo. Ressalta-se a participação do enfermeiro como educador, constituindo como um desafio para esse profissional a sensibilização das pessoas para a prevenção desta síndrome.

Evolução do tratamento de pacientes diabéticos utilizando o protocolo staged diabetes management. ZANETTI, Maria Lúcia et al. Objetivo: Descrever a evolução do tratamento de pacientes diabéticos por equipe multiprofissional utilizando o Protocolo Staged Diabetes Management. Metodologia: Estudo descritivo, prospectivo e longitudinal, realizado em 12 meses com pacientes diabéticos $(n=54)$. Os dados foram coletados mediante entrevista em três pontos: P0 início do estudo; P6 seis meses após o início; e P12 final do estudo. Resultados: Houve aumento no cumprimento do plano alimentar pelos pacientes diabéticos, de $61,1 \%$ no $\mathrm{P0}$ para $92,6 \%$ no $\mathrm{P} 12$. No que se refere à atividade física, observou-se aumento de $57,4 \%$ no P0 para $66,7 \%$ no P12. Verificou-se também um aumento da cobertura medicamentosa no tratamento do diabetes.

O cuidado à pessoa diabética e as repercussões na família. ZANETTI, Maria Lúcia et al. Objetivo: compreender as repercussões na família da assistência oferecida após implementação de um programa educativo em diabetes. Metodologia: Entrevistamos seis familiares de pacientes diabéticos de um centro universitário de Ribeirão Preto-SP, em 2007. A análise temática dos dados possibilitou identificar três temas: familiares reconhecem que o Centro constitui um diferencial para adesão ao plano alimentar, atividade física e medicamentos; o Centro é reconhecido como espaço educativo para convívio e controle do diabetes; o paciente como elemento que multiplica e expande o conhecimento acerca do diabetes na família. Resultados: apontam que o programa educativo repercutiu favoravelmente na família, ampliando seu repertório de conhecimentos sobre o tratamento. O apoio do núcleo familiar é fundamental na adesão ao tratamento.

Orientação nutricional da criança diabética: o papel da família e dos profissionais de saúde. DIONÍSIO, Gisele de Fátima et al. Objetivo: Identificar o papel da família e da equipe multiprofissional de saúde na orientação nutricional da 
criança diabética. Metodologia: Estudo de revisão bibliográfica com base em artigos científicos de língua portuguesa, publicados em periódicos indexados no período de 2000 a 2010. Foi feito um levantamento nos bancos de dados Literatura LatinoAmericana e do Caribe em Ciências da Saúde e Scientific Electronic Library Online. Resultados: os autores foram unânimes em apontar que o apoio e a motivação da família influenciam a criança de forma positiva e representa o ponto chave para 0 controle da doença e a qualidade de vida dos portadores.

Percepção dos profissionais de saúde sobre o trabalho interdisciplinar nas estratégias educativas. DAVID, Gizele Ferreira e TORRES, Heloisa de Carvalho. Objetivo: Objetivou-se analisar a percepção dos profissionais de saúde sobre as estratégias educativas em diabetes realizadas por equipe interdisciplinar na atenção primária. Metodologia: Um total de doze profissionais de saúde inseridos em unidades básicas, Belo Horizonte MG, março-abril, 2011, participaram dos grupos focais objetivando problematizar a experiência do trabalho interdisciplinar na prática educativa e os fatores que agem como facilitadores ou barreiras para a efetividade da educação em diabetes. Resultados: Os resultados foram organizados a partir da identificação das categorias: 1) Questões relacionadas e/ou atribuídas à própria clientela, 2) Capacitação profissional; 3) Trabalho multidisciplinar e 4) Planejamento das ações educativas. O estudo mostra a importância de se planejar e avaliar as práticas educativas, a inserção do trabalho interdisciplinar nas intervenções como forma a estabelecer estratégias de promoção, prevenção e controle da doença.

Políticas Públicas e direitos dos usuários do Sistema Único de Saúde com diabetes mellitus. SANTOS, Ellen Cristina Barbosa dos et al. Este estudo aborda a relação entre políticas publicas e direitos dos usuários com diabetes mellitus quanto aos insumos utilizados no tratamento da doença, sob o ponto de vista das normas e procedimentos legais de amparo a essa população.

\section{Pontos Básicos de um Programa de Educação ao Paciente com Diabetes} Melito Tipo 1. LEITE, Samara A. Oliveira et al. Objetivo: Quais as recomendações e diretrizes de educação em diabetes existentes? Existem evidências para recomendar a adaptação de determinado programa segundo a faixa etária dos pacientes? Os programas de educação são efetivos na melhora dos níveis de HbA1c? Metodologia: Foram revisados 40 artigos, publicados entre 2000 e 2007, sobre educação em DM1 em crianças, adolescentes, adultos e usuários de bomba 
de infusão contínua de insulina, além de incluir o resumo das diretrizes da IDF, da ADA, da SBD, da AADE, do IDC, e outras peculiaridades para o contexto de saúde pública e privada Resultados: O portador de diabetes e sua família devem ser treinados a fazer decisões efetivas de autocuidado em sua rotina diária. $O$ aprimoramento do paciente no automanejo aproxima o valor da $\mathrm{HbA1c}$ ao adequado para sua faixa etária. A educação individual e a em grupo apresentam equivalência na melhora do controle metabólico. Existe uma correlação positiva entre o tempo de educação e o controle da glicemia.

Práticas educativas em diabetes Mellitus: revisão integrativa da literatura. BORBA, Anna Karla de Oliveira Tito et al Objetivo: identificar a produção científica multiprofissional sobre as práticas educativas para indivíduos com diabetes. Metodologia: Revisão integrativa de literatura, disponíveis nas bases de dados: Literatura Latino-Americana em Ciências da Saúde (LILACS), Medical Literature end Retrieval System Online (Medline), Índice Bibliográfico Español en Ciencias de la Salud (Ibecs) e a Base de Dados em Enfermagem (BDENF), no período de 1999 a 2009. Resultados mostram que as práticas educativas são desenvolvidas, principalmente, para adultos e idosos de até 80 anos, e envolvem temáticas que refletem o cotidiano do viver com diabetes. Estas práticas são difundidas, principalmente através de grupos, trazendo benefícios, não só para o indivíduo com diabetes, mas também para o profissional de saúde. Visualiza-se o processo de mudança do paradigma da educação tradicional, para uma educação problematizadora e dialógica, com vistas à promoção da saúde.

Reflexão sobre o cuidado de enfermagem e sua aproximação com a prática social. SILVA, Elizangela M. F. da e LACAVA, Simone. Objetivo: é uma reflexão sobre o cuidado de enfermagem buscando relacioná-lo com a prática social. Metodologia: Para levantamento dos dados foram consultados bancos de dados como, Scielo, Lilacs e Medline, com recorte temporal dos últimos 10 anos. Resultado: Compreender o valor do cuidado de enfermagem como prática social requer uma concepção ética que contemple a vida como um bem valioso em si, começando pela valorização da própria vida para respeitar a do outro, em sua complexidade, suas escolhas, inclusive a escolha da enfermagem como uma profissão.

Reflexões sobre o Diabetes Tipo 1 e sua relação com o Emocional. MARCELINO, Daniela Botti e CARVALHO, Maria Dalva de Barros. Objetivo: Este 
artigo tem como tema central o diabetes tipo 1 ou infanto-juvenil. Tendo em vista as repercussões que esta doença crônica traz. Metodologia: este trabalho levantou dados bibliográficos que subsidiassem reflexões sobre os aspectos emocionais vivenciados pelas crianças diabéticas. Resultado: mostrou que o emocional influi na etiologia do diabetes e que o diabetes também influi no emocional desta criança. Isso ocorre devido aos cuidados incessantes para controle da doença, medo das possíveis complicações, mal-estar provocado pelos sintomas de hiper e hipoglicemia, o fato de ser "diferente". Sendo assim, é necessário um acompanhamento desta criança não só por médicos, mas também por outros profissionais da saúde, entre eles o psicólogo, objetivando elaboração dos aspectos referentes à doença e suas repercussões emocionais.

Trabalho Transmultiprofissional no Cuidado a Adolescentes com Diabetes: Uma Análise Crítica. SIMÃO, Vilma Margarete etal. Objetivo: $O$ artigo apresenta os resultados de pesquisa aplicada para avaliação das atividades do Programa de Extensão em Saúde da Universidade Regional de Blumenau. Metodologia: Uso do instrumento de entrevista estruturada e de discussão grupal, foram coletados dados junto aos adolescentes com diabetes e aos seus cuidadores responsáveis. As questões das entrevistas abordavam os seguintes temas: adesão e autonomia no cuidado; apoio social; relações familiares e com os profissionais de saúde. Os Resultados: Indicam fragilidade da prática de atenção integral da equipe profissional que compõe o Programa por decorrência de dificuldades do estabelecimento de uma comunicação horizontal e da questão social que interfere nas condições de acesso ao pleno autocuidado. Na discussão dos resultados dos dados pelo grupo foi obtido novo dado e no mesmo tempo foi desenvolvido ações para a melhoria do cuidado, portanto, a metodologia utilizada é de pesquisa-ação

Uma experiência no cuidado a adolescentes com diabetes. SIMÃO, Vilma Margarete et al. Objetivo: Apresentar a experiência que utiliza a base teórica de Eugênio Mendes do cuidado e o princípio de integralidade do Ministério da saúde. Metodologia: $O$ artigo apresenta uma reflexão sobre uma prática de cuidado junto a adolescentes com diabetes mellitus tipo 1 e suas respectivas famílias, realizada no Ambulatório Universitário da Universidade Regional de Blumenau, desenvolvida por uma equipe de profissionais de saúde em programa de extensão universitária. Resultado: viu-se que por meio da troca de saberes entre as diferentes profissões que compõem a equipe multiprofissional através da socialização das experiências de 
cuidado individual dos adolescentes diabéticos, a equipe enriqueceu o trabalho intermultidisciplinar, onde as percepções disciplinares se agregaram possibilitando a melhoria nas condições de efetivação do cuidado integral por meio da apropriação da totalidade biopsicossocial do sujeito do cuidado.

Vivendo com o Diabetes: A experiência contada pela Criança. MOREIRA, Patrícia Luciana e DUPAS, Giselle. Objetivo: compreender a experiência da criança na vivência com a doença. Metodologia: Os referenciais teórico e metodológico utilizados foram o Interacionismo Simbólico e a Teoria Fundamentada nos Dados, respectivamente. Entrevistou-se 12 crianças na faixa etária entre 7 e 14 anos. Resultados: A vivência com o diabetes é algo que a criança enfrenta a cada dia, desde o momento do diagnóstico, tendo limitações na dieta, a inserção da insulinoterapia, a mudança no estilo de vida, fatos esses que desencadeiam sentimentos que oscilam entre medo, insegurança, revolta, aceitação e adaptação.

\subsection{Criança e Adolescente}

O impacto do Diagnostico da Diabetes Mellitus Tipo 1 para crianças e adolescentes é muito marcante, pois mudanças ocorrem, e os mesmos se pergunta, " por que comigo?". Neste momento tais pacientes são imbuídos de sentimentos como: medo, desespero, entre outros. (MOREIRA E DUPAS, 2006).

A alimentação para crianças e adolescentes portadores de DM tipo 1 é essencial para o controle da doença, porem para os mesmos se torna uma grande dificuldade por não poderem se alimentar do que e quando desejarem, principalmente quando estão em companhia dos amigos não diabéticos. (FIALHO ET AL, 2011)

Moreira e Dupas (2006) ressaltam que o antes e o depois do diagnóstico da DM tipo 1 foi uma forte característica percebido nos participantes da pesquisa, devido ao fato de a partir deste momento terem que mudar seu modo de vida no tocante à alimentação, uso de insulina

Santos et al citado por Fialho et al (2011, p.151), explicam que a relação com a dieta alimentar não é só no sentido de alimentos sólidos, mas está relacionado “...a uma gama de emoções e sentimentos, alem de valores culturais, o que torna árduo o cumprimento das recomendações". 
Com o delinear da doença, os significados atribuídos vão se modificando e por conseguinte a percepção da patologia. (MOREIRA E DUPAS, 2006)

Marcelino e Carvalho (2005) acreditam que a diabetes possui uma relação com o estado emocional do individuo, bem como na conseqüência da mesma, por ser esta uma doença psicossomática.

Tal relação também é percebida no controle da doença, momento que o paciente se torna escravo do tratamento. O controle do Diabetes pelas crianças e adolescentes é de difícil execução pois trazem "...uma ambivalência de sentimentos entre fazer aquilo que deseja e o que deve fazer". (MARCELINO E CARVALHO, 2005, p.76)

A escuta com relação à doença permite a melhora da autoestima dos pacientes. Moreira e Dupas (2006, p. 31) explicam que além da escuta “... é preciso compreender seus comportamentos, medos e anseios e apoiá-los nos diversos âmbitos dessa experiência, que abarca principalmente o físico, o emocional e o social".

A negação ou a aceitação da doença estão relacionadas aos sentimentos gerados pela patologia. A negação da doença ou parte do tratamento é um mecanismo de defesa que o paciente utiliza devido a dificuldade de encará-la

Vê-se então a necessidade de um trabalho que abarque vários os profissionais da área da saúde, isto é, de uma equipe multidisciplinar. (MOREIRA E DUIPAS, 2006).

De acordo com Marcelino e Carvalho (2005) há uma relação intrínseca entre - Diabetes e o emocional, portanto, a necessidade de um trabalho psicológico individual ou em grupo é primordial para que os mesmos possam aceitar e conviver com a patologia.

As crianças e adolescentes diabéticos necessitam de um trabalho psicológico, que pode ser individual, onde os sentimentos expressos poderão ser trabalhados; e em grupo para que se sintam pertencentes ao grupo e que existem outros na mesma situação. Ambos os trabalhos permitirão uma resposta mais efetiva para o tratamento de DM tipo 1, propiciando melhor qualidade de vida. (MARCELINO E CARVALHO 2005, 2008).

O acompanhamento individualizado para melhora do quadro de DM tipo 1 é devido para que se possa descobrir a percepção que o paciente possui sobre a sua patologia. O Acompanhamento psicológico em grupo é fundamental para ajudar na 
elaboração de sentimentos de medo, de preocupação e de dor gerados pela patologia. (FIALHO ET AL, 2011).

Nesse momento a atuação da equipe multidisciplinar é primordial, pois atuará tanto na parte médica quanto na psicológica, ajudando o paciente a lhe dar com tal situação.

\title{
4.2 Família
}

O Diagnostico da Diabetes Mellitus Tipo 1 para os familiares do paciente é algo bastante assustador, pois, a partir desse momento há mudanças drásticas na vida do paciente e de seus familiares. "Na rotina cotidiana, mudaram os hábitos e as obrigações, mudaram as prioridades. A partir dali, são novas regras e normas, que devem ser seguidas rigidamente, sob a pena de haver graves complicações no estado de saúde do filho". (BRITO E SADALA, 2009, P. 956).

\begin{abstract}
Ao observar uma família em que um dos entes encontra-se acometido pelo DM, percebe-se que não só o diabético sente as consequências de estar doente, mas todos passam a vivenciar essa nova realidade. As mães rotineiramente alteram suas atividades em prol do bem-estar do filho doente, favorecendo o tratamento $\mathrm{e}$ acompanhamento da doença crônica, pois as transformações ocasionadas pelo diagnóstico de DM são inevitáveis. (CORREIA JR ET AL, 2014, p.62)
\end{abstract}

Sentimentos tais como: medo, angustia, são vivenciados devido ao fato da DM tipo 1 ser incurável e trazer complicações geradas pelo mal controle da patologia. (BRITO E SADALA, 2009).

Brito e Sadala (2009, p. 957) ressaltam que o sentimento dos pais é de impotência por não “...garantir-lhes a segurança e um futuro". Os pais lutam para ajudar o filho a não fraquejar, a não desistir, por não aceitarem a doença, portanto o cuidar do filho "...e uma resposta dos pais às necessidades do filho, que depende das ações paternas". (p. 958).

Para Correia Jr et al (2014, p.66) é de extrema importância “... uma abordagem psicológica e multidisciplinar para o diabético e seus entes, na busca de um melhor controle clínico, prevenção de complicações a longo prazo e melhoria da qualidade de vida". (CORREIA JR ET ALL, 2014, p. 66). 


\subsection{Educação e Equipe Multidisciplinar}

O adoecimento de um membro da família acaba adoecendo a todos e para tal o envolvimento de toda a família é ideal para um bom prognóstico da patologia. (DIONÍSIO ET AL, 2011)

$\mathrm{Na}$ descoberta do diagnostico pela família, duvidas, incertezas, medos são vivenciados por ser a Diabete Mellitus tipo 1, uma doença crônica com tratamento e sem cura. (DIONíSIO ET AL, 2011)

As mães buscam então vários especialistas para a definição do diagnostico. Motivação para realização das atividades físicas, uma nova dieta alimentar, integração com a equipe de saúde são algumas dificuldades com as quais as mães dos pacientes se deparam. (DIONíSIO ET AL, 2011)

A busca da autonomia para a criança portadora de DM tipo 1 baseia-se na educação, pois novos comportamentos e atitudes passarão a fazer parte da vida do paciente. (LEITE ET AL, 2008)

È imprescindível que nesse processo da DM tipo 1 ocorra o processo de educação para que os pacientes engajem no autocuidado e na “... adesão ao esquema terapêutico e preventivo, a fim de que ele atinja o melhor nível de bemestar". (DAMO ET AL, 2013, p.185).

Segundo Dionísio et al (2011, p. 50) “... o apoio e a motivação da família influenciam a criança de forma positiva e representam o ponto chave para o controle da doença e a qualidade de vida dos portadores"

A inclusão da família no tratamento da DM tipo 1 é importantíssima visto que é ela quem conhece o portador. (PEIXOTO E SILVA, 2011).

A adesão do nutricionista na atenção primária é primordial visto que é através deste profissional a prescrição de uma dieta alimentar especifica para o portador de DM tipo 1. (DIONÍSIO ET AL, 2011)

\subsection{O Autocuidado}

Nascimento et al (2011) ensinam que o agravo da doença pode ser propiciado pelo fato da criança não saber sobre a patologia e as suas implicações diárias. Nesse sentido é necessário o acompanhamento de um profissional especializado, 
pois é através da educação que poderá entender sobre a patologia e engajar no tratamento.

Simão et al (2013, p.4) ressaltam que a pratica multiprofissional ainda não é uma realidade e sim uma meta o que distancia o processo do autocuidado, “... pois a equipe ainda não está atuando de modo efetivo no empoderamento para o exercício do autocuidado e frágil está o cuidado apoiado".

\footnotetext{
A educação adequada no momento da descoberta do diabetes e o acompanhamento da criança, a criação de vínculos com ela e sua família, a valorização do seu conhecimento e a troca de experiências entre as crianças e entre familiares são questões essenciais que devem receber prioridade do enfermeiro. (NASCIMENTO ET AL, 2011, P.768)
}

O Conflito e o não envolvimento da família nas questões da Diabetes podem gerar segundo estudiosos "baixa adesão ao tratamento, autocuidado inapropriado, controle metabólico e dificuldades na transferência das habilidades do cuidado dos pais para os filhos". (NASCIMENTO ET AL, 2011, p. 768).

Uma questão importante é com relação aos hábitos alimentares. A adesão da família à rotina alimentar propicia ao filho uma inserção e uma maior aceitação da doença, pois não se sente diferente dos demais integrantes da família. (SIMÃO ET $A L, 2013)$.

Diante dos estudos efetuados por Nascimento et al (2011, p.768) verificou-se que a escola é uma peça importante no desenvolvimento do autocuidado, pois esta se torna um espaço fundamental devido a criança passar boa parte do seu dia, criar vínculos saudáveis, e para o seu próprio desenvolvimento. Nesse sentido "A aproximação da equipe de saúde nas escolas mostra-se essencial, pois este ambiente é cenário-chave de atuação conjunta entre profissionais, criança e atores da escola, caso se almeje um cuidado de saúde de qualidade, em especial quando se trata do diabetes que exige manejo diário". 


\section{CONCLUINDO:}

A Diabetes Mellitus Tipo 1, que ataca crianças e adolescentes é considerada uma doença crônica por não ser curável e poder ter complicações serias chegando ao óbito.

Tal patologia gera no paciente e familiares, sentimentos de menos valia, impotência, desespero, dúvida, inconformismo devido a mesma provocar inúmeras alterações no portador e nos familiares.Uma mudança que ocorre é a dos hábitos alimentares. Tal situação pode gerar conflitos familiares propiciando a baixa adesão do portador ao tratamento.

É imprescindível aliar a família aos conhecimentos técnicos e tal só pode ser executado por profissionais especializados que deverão ter um diálogo aberto, um linguajar acessível buscando o engajamento do portador e dos familiares no tratamento.

Diante dos estudos efetuados verificou-se que a educação para os portadores de Diabetes Melittus 1 deixa a desejar, possivelmente pelo despreparo dos profissionais.

Portanto acredita-se que no momento em que haja maior adesão de profissionais na área da educação em Diabetes, possibilitará maior fluxo de aceitação dos pacientes e dos familiares evitando complicações serias e muito menos o óbito. 


\section{REFERÊNCIAS}

ALMEIDA, José Paulo Correia De. IMPACTO DOS FACTORES PSICOLÓGICOS ASSOCIADOS À ADESÃO TERAPÊUTICA, AO CONTROLO METABÓLICO E À QUALIDADE DE VIDA EM ADOLESCENTES COM DIABETES TIPO 1. DISSERTAÇÃO DE CANDIDATURA AO GRAU DE DOUTOR EM PSICOLOGIA CLÍNICA APRESENTADO AO DEPARTAMENTO DE PSICOLOGIA DA UNIVERSIDADE DO MINHO. BRAGA 2003.

ALMEIDA, Paulo e PEREIRA, M. Graça. ESCALA COMPORTAMENTAL DE SUPORTE SOCIAL FAMILIAR PARA ADOLESCENTES COM DIABETES (DFBS)Psicologia, Saúde e Doenças [en linea] 2011, 12 (Sin mes). Disponível em: <http://www.redalyc.org/articulo.oa?id=36222221002> $\quad$ ISSN 1645-0086. Acessado em 10/01/2016.

ANDRADE, LBP. Educação infantil: discurso, legislação e práticas institucionais [online]. São Paulo: Editora UNESP; São Paulo: Cultura Acadêmica, 2010. 193 p. ISBN 978-85-7983-085-3. Disponível em: Scielo Books.

BORBA, Anna Karla de Oliveira Tito et al . Práticas educativas em diabetes Mellitus: revisão integrativa da literatura. Rev. Gaúcha Enferm., Porto Alegre, v. 33, n. 1, p. 169-176, Mar. 2012 Disponível em: http://www.scielo.br/scielo.php?script=sci arttext\&pid=S198314472012000100022\&lng=en\&nrm=iso. Acessado em 18/02/2015. http://dx.doi.org/10.1590/S1983-14472012000100022.

BRASIL. Ministério da Saúde. Gabinete do Ministro. Portaria no 371, de 04 de março de 2002. Disponível em: http://bvsms.saude.gov.br/bvs/saudelegis/gm/2002/prt0371 04032002 rep.html.

Acessado em: 20/03/2016.

BRASIL. Ministério da Saúde. Secretaria de Atenção à Saúde. Departamento de Atenção Básica. Diabetes Mellitus / Ministério da Saúde, Secretaria de Atenção à Saúde, Departamento de Atenção Básica. - Brasília: Ministério da Saúde, 2006. 64 p. il. - (Cadernos de Atenção Básica, n. 16) (Série A. Normas e Manuais Técnicos). Disponível no site: http://bvsms.saude.gov.br/bvs/publicacoes/diabetes mellitus.PDF Acessado em 25.10.2015.

BRASIL. Ministério da Saúde. Secretaria de Atenção em Saúde. Departamento de Ações Programáticas Estratégicas. Diretrizes para a atenção integral à saúde de adolescentes e jovens na promoção, proteção e recuperação da saúde. Brasília: Ministério da Saúde, 2010. 132p. Disponível em: 
http://pt.slideshare.net/elosdasaude/diretrizes-nacionais-41217376. Acessado em 18/02/2016.

BRITO, Thais Basso de e SADALA, Maria Lúcia Araújo. Diabetes mellitus juvenil: a experiência de familiares de adolescentes e pré-adolescentes. Ciênc. saúde coletiva [online]. 2009, vol.14, n.3 pp.947-960. Disponível em: http://www.scielo.br/scielo.php?script=sci arttext\&pid=S1413-

$81232009000300031 \& \operatorname{lng}=$ en\&nrm=iso. $\quad$ ISSN 1678-4561. http://dx.doi.org/10.1590/S1413-81232009000300031. Acessado em 15/01/2016.

CALLIARI, Luis Eduardo P. e MONTE, Osmar. Abordagem do Diabetes Melito na Primeira Infância. Arq Bras Endrocrinol Metab 2008;52/2. Disponível no site: http://www.scielo.br/pdf/abem/v52n2/11.pdf. Acessado em 25.10.2015.

CARVALHO, Alysson et all. Adolescência. Belo Horizonte: UFMG, 2012.

CASTRO, Lelma et al. Cetoacidose diabética em crianças: perfil de tratamento em hospital universitário. Rev. Assoc. Med. Bras., São Paulo, v. 54, n. 6, p. 548-553, Dec. 2008. Disponível

em: http://www.scielo.br/scielo.php?script=sci arttext\&pid=S0104$42302008000600021 \& \operatorname{lng}=$ en\&nrm=iso. Acessado em 18/02/2016. http://dx.doi.org/10.1590/S0104-42302008000600021.

CORREIA JÚNIOR, Paulo Cesar Teles et al. Apreender as repercussões do diabetes mellitus em crianças sob a ótica das mães. Revista Rene. 2014 jan-fev; 15(1):60-9. Disponível em: http://www.revistarene.ufc.br/revista/index.php/revista/article/view/1368. Acessado em 15/01/2016.

CORRER, Rinaldo et al. Avaliação do cotidiano e enfrentamento de adolescentes com diabetes mellitus 1. SALUSVITA, Bauru, v. 32, n. 3, p. 243-263, 2013. Disponível

em: http://www.usc.br/biblioteca/salusvita/salusvita v32 n3 2013 art 03.pdf. Acessado em 18/02/2016.

COSTA, Mônica Barros e CASTRO Antônio Paulo André de. Abordagem interdisciplinar no tratamento do diabetes melitus tipo 2: da teoria à pratica. Extramuros, Petrolina-PE, v. 1, n. 2, p. 30-37, ago./dez. 2013. Disponível em: http://www.periodicos.univasf.edu.br/index.php/extramuros/article/view/301/12 Acessado em 15/01/2015. 
DAMO, Nevoni Goretti et al. A Multiprofissionalidade do cuidado com o paciente diabético tipo 1: uma experiência. Em Extensão 179 , Uberlândia, v. 12, n. 2, p. 174185, jul. / dez. 2013. Disponível em: www.seer.ufu.br/index.php/revextensao/article/download/.../13559. Acessado em $\underline{15 / 01 / 2016 .}$

DAVID, Gizele Ferreira e TORRES, Heloisa de Carvalho. Percepção dos profissionais de saúde sobre o trabalho interdisciplinar nas estratégias educativas em Diabetes. Rev. Rene. 2013; 14 (6): 1185-92. Disponível em: http://www.revistarene.ufc.br/revista/index.php/revista/article/view/1366/pdf.

Acessado em: 18/01/2015.

DIB, Sergio Atala et al. Diabetes Melito tipo 1: da Pesquisa à Clínica. Arq Bras Endocrinol Metab, São Paulo, v. 52, n. 2, p. 143-145, Mar. 2008. Disponível em: http://www.scielo.br/scielo.php?script=sci arttext\&pid=S0004-

27302008000200001\&lng=en\&nrm=iso. Acessado em 18/01/2016. 2016. http://dx.doi.org/10.1590/S0004-27302008000200001.

DIONÍSIO, Gisele de Fátima et al. Orientação nutricional da criança diabética: o papel da família e dos profissionais de saúde. Cuidarte Enfermagem. Catanduva, SP Volume 5 Número 1 p. 1-72 janeiro/junho 2011 Semestral. Disponievl em: http://www.fundacaopadrealbino.org.br/facfipa/ner/pdf/CuidArte\%20Enfermagem\%20 v.\%205\%20n.\%201\%20jan.jun.\%202011.pdf . Acessado em 15/01/2016.

DIRETRIZES SBD 2013-2014. Diretrizes da Sociedade Brasileira de Diabetes: 2013-2014/Sociedade Brasileira de Diabetes; [organização José Egidio Paulo de Oliveira, Sérgio Vencio]. - São Paulo: AC Farmacêutica, 2014.

FIALHO, Flávia Andrade et al. Crianças e Adolescentes com Diabetes Mellitus: cuidados/implicações para a enfermagem. Revista Baiana de Enfermagem, Salvador, v. 25, n. 2, p. 145-154, maio/ago. 2011. Disponível no site: http://www.portalseer.ufba.br/index.php/enfermagem/article/view/4820. Acessado em 15/01/2015.

FLISCH, Tácia Maria Pereira ET AL. Como os profissionais da atenção primária percebem e desenvolvem a Educação Popular em Saúde? Interface (Botucatu)[online]. 2014, vol.18, suppl.2 pp.1255-1268. Disponível em: http://www.scielo.br/scielo.php?script=sci arttext\&pid=S1414-32832014000601255 . Acessado em: 15/01/2015.

Gil, Antonio Carlos. Métodos e técnicas de pesquisa social. 6ª . ed. - São Paulo : Atlas, 2008. 
GROSS, Jorge L. Diabetes Melito: Diagnóstico, Classificação e Avaliação do Controle Glicêmico. Arq Bras Endocrinol Metab vol 46 nำ 1 Fevereiro 2002. Disponível no site: http://scielo.br/pdf/abem/v46n1/a04v46n1.pdf . Acessado em 25.10.2015.

LEITE, Silmara A. Oliveira et al. Pontos Básicos de um programa de Educação ao Paciente com Diabetes Mellitus Tipo 1. Arq Bras Endocrinol Metab, São Paulo, v. 52, n. 2, p. 233-242, Mar. 2008 . Disponível em: http://www.scielo.br/scielo.php?script=sci arttext\&pid=S000427302008000200010\&lng=en\&nrm=iso. Acessado em: 15/01/2016. http://dx.doi.org/10.1590/S0004-27302008000200010.

MARCELINO, Daniela Botti e CARVALHO, Maria Dalva de Barros. Reflexões sobre o Diabetes Tipo 1 e sua Relação com o Emocional. Psicologia: Reflexão e Crítica, 2005, 18(1), P.72-77. Disponível no site: http://www.scielo.br/scielo.php?script=sci arttext\&pid=S0102-79722005000100010. Acessado em 15.01.2015.

MARCELINO, Daniela Botti e CARVALHO, Maria Dalva de Barros Carvalho. Aspectos Emocionais de crianças diabéticas: experiência de atendimento em grupo. Psicologia em Estudo, Maringá, v. 13, n. 2, p. 345-350, abr./jun. 2008. Disponível no site: http://www.scielo.br/pdf/pe/v13n2/a17v13n2.pdf. Acessado em 15/01/2016.

MARCON, Sônia Silva et al. Assistência às crianças com Diabetes tipo 1 na visão da família: uma abordagem qualitativa. Online Brazilian Journal of Nursing, [S.I.], v. 8, n. 2, july 2009. ISSN 1676-4285. Disponível em: $<$ http://www.objnursing.uff.br/index.php/nursing/article/view/j.1676-

4285.2009.2262/494 >. Acessado em: 15/01/2016. doi:http://dx.doi.org/10.5935/16764285.20092262 .

MOREIRA, Patrícia Luciana E DUPAS Giselle. Vivendo com o Diabetes: a experiência contada pela criança. Rev Latino-am Enfermagem 2006 janeirofevereiro; 14(1): 25-32. Disponível no site: http://www.eerp.usp.br/rlae. Acessado em 15.01.2015.

NASCIMENTO, Lucila Castanheira et al. Diabetes mellitus tipo1: evidencias da literatura para seu manejo adequado, na perspectiva de crianças. Rev. esc. enferm. USP, São Paulo, v. 45, n. 3, p. 764-769, June 2011. Disponível em: http://www.scielo.br/scielo.php?script=sci arttext\&pid=S0080-

62342011000300031\&lng=en\&nrm=iso. Acessado em 15/01/2016. http://dx.doi.org/10.1590/S0080-62342011000300031.

PEIXOTO, Gilciane Vianna e SILVA, Rosângela Marion da. Estratégias Educativas ao portador de Diabetes Mellitus: Revisão sistemática. Revista Espaço para a 
Saúde, Londrina, v.13, n.1, p.74-81, dez.2011. Disponível em: http://www.uel.br/revistas/uel/index.php/espacoparasaude/article/viewFile/9729/pdf.

Acessado em 15/01/2015.

PERES, Denise Siqueira et al. Dificuldades dos pacientes diabéticos para o controle da doença: sentimentos e comportamentos. Rev. Latino-Am. Enfermagem, Ribeirão Preto, v. 15, n. 6, p. 1105-1112, Dec. 2007. Disponível em: http://www.scielo.br/scielo.php?script=sci arttext\&pid=S0104-

$11692007000600008 \&$ Ing=en\&nrm=iso. Acessado em 15/02/2015. http://dx.doi.org/10.1590/S0104-11692007000600008.

PINTO, Mauro Scharf. Diagnóstico clínico e laboratorial do diabetes tipo 1. Diagnóstico e Tratamento do diabetes tipo 1. Disponível em: http://saudedafamilia.ufms.br/manager/titan.php?target=openFile\&fileld=477.

Acessado em 15/02/2015.

ROSSATO, Luciano Alves et al. Estatuto da Criança e do Adolescente Comentado. 2a Ed. rev. e ampliada. São Paulo: Ed. Revista dos Tribunais, 2011.

SANTOS, Ellen Cristina Barbosa dos et al. Políticas Públicas e direitos dos usuários do Sistema Único de Saúde com diabetes mellitus. Rev Bras Enferm, Brasília 2011 set-out; 64(5): 952-7. Disponível em: http://www.scielo.br/pdf/reben/v64n5/a23v64n5.pdf. 16. Acessado em 15/01/2016.

SESTERHEIM, Patrícia et al. Diabetes mellitus tipo1: multifatores que conferem suscetibilidade à patogenia auto-imune. Scientia Medica, Porto Alegre, v. 17, n. 4, p. 212-217, out./dez. $2007 . \quad$ Disponível em: http://revistaseletronicas.pucrs.br/ojs/index.php/scientiamedica/article/viewFile/1654/ 2631. Acessado em 18/02/2016.

SILVA, Elizangela M. F. da e LACAVA, Simone. Reflexão sobre o cuidado de enfermagem e sua aproximação com a prática social. Rev Enferm UNISA 2010; 11(1): 53-6. Disponível em: http://www.unisa.br/graduacao/biologicas/enfer/revista/arquivos/2010-1-09.pdf. Acessado em 18/02/2016.

SILVA, Francisco das Chagas Lima e CHAGAS, Antonio José das. Manual de Urgências em Pronto-Socorro. Capítulo 54 Cetoacidose Diabética 6ª Ed. 1999. Rio de Janeiro/RJ. Medsi Editora Médica e Científica Ltda. Disponível em: http://www.rogerioultra.com.br/arquivos/Livro\%20$\% 20$ Manual\%20de\%20Urgencias\%20em\%20Pronto-Socorro.pdf. Acessado em 18/02/2016. 
SILVA, Ivani Nonato (Coord.) et al. PROGRAMA DE ASSISTÊNCIA AMBULATORIAL ÀS CRIANÇAS E ADOLESCENTES DIABÉTICOS DO HOSPITAL DAS CLíNICAS DA UFMG. Divisão de endocrinologia da criança e do Adolescente. Departamento de pediatria. Faculdade de medicina. Hospital das clínicas. UNIVERSIDADE FEDERAL DE MINAS GERAIS. Belo Horizonte, 2004.

SIMÃO, Vilma Margarete et al. UMA EXPERIÊNCIA NO CUIDADO A ADOLESCENTES COM DIABETES. 2013. Disponível em: http://www.convibra.org/upload/paper/2013/76/2013 76 7558.pdf. Acessado em 18/02/2016.

SIMÃO, Vilma Margarete et al. TRABALHO TRANSMULTIPROFISSIONAL NO CUIDADO A ADOLESCENTES COM DIABETES: UMA ANÁLISE CRÍTICA. 2013. Disponível em: http://www.convibra.org/upload/paper/2013/70/2013 70 7232.pdf. Acessado em 18/02/2016.

SOCIEDADE BRASILEIRA DE DIABETES. Tratamento e Acompanhamento do Diabetes Mellitus. Diretrizes da Sociedade Brasileira de Diabetes. 2007. Disponível em: http://www.cff.org.br/userfiles/file/noticias/Diretrizes SBD 2007\%5B1\%5D.pdf . Acessado em 18/02/2015.

TORRES, Heloisa de Carvalho et al. A experiência de jogos em grupos operativos na educação em saúde para diabéticos. Cad. Saúde Pública, Rio de Janeiro, 19(4):1039-1047, jul-ago, 2003. Disponível em: http://www.scielo.br/pdf/csp/v19n4/16853.pdf . Acessado em 15/02/2015.

TRENTINI, Mercedes et al. A responsabilidade social da enfermagem frente à política da humanização em saúde. Colômbia Médica, vol. 42, núm. 2 Supl. 1, abriljunio, 2011, pp. 95-102. Universidad del Valle Cali, Colômbia. Disponível em: http://www.redalyc.org/pdf/283/28322504012.pdf. Acessado em 18/02/2016.

ZANETTI, Maria Lúcia e MENDES, Isabel Amélia Costa. Caracterização de crianças e adolescentes com Diabetes Tipo 1 em seguimento terapêutico. R. gaúcha Enferm. Porto Alegre, v.21, n.1, p.82 - 99, jan.2000. Disponível em: http://seer.ufrgs.br/index.php/RevistaGauchadeEnfermagem/article/view/4307/2270 . Acessado em 18/01/2015.

ZANETTI, Maria Lúcia et al . Evolução do tratamento de pacientes diabéticos utilizando o protocolo staged diabetes management. Acta paul. enferm. São Paulo, v.20, n.3, p.338-344, Sept. 2007. Disponível em: http://www.scielo.br/scielo.php?script=sci arttext\&pid=S0103$21002007000300016 \&$ Ing=en\&nrm=iso. Acessado em 18/02/2016. http://dx.doi.org/10.1590/S0103-21002007000300016. 
ZANETTI, Maria Lúcia et al . O cuidado à pessoa diabética e as repercussões na família. Rev. bras. enferm., Brasília, v. 61, n. 2, p. 186-192, Apr. 2008. Disponível em: $\quad$ http://www.scielo.br/scielo.php?script=sci arttext\&pid=S003471672008000200007\&lng=en\&nrm=iso. Acessado em 15/02/2015. http://dx.doi.org/10.1590/S0034-7167200800020000. 